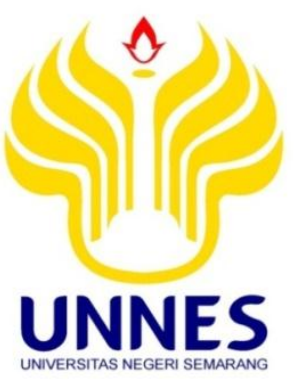

\title{
STRATEGI DAN INOVASI PEMBELAJARAN SENI MUSIK DI SMP NEGERI 34 SEMARANG
}

\author{
SKRIPSI \\ Untuk memperoleh gelar Sarjana Pendidikan \\ Program Studi Pendidikan Seni Musik \\ oleh \\ Nama $\quad$ : Ahadiah Ana Tamala \\ NIM : $\quad: 2501411008$ \\ Program Studi $\quad$ : Pendidikan Seni Musik \\ Jurusan $\quad$ : Pendidikan Seni, Drama, Tari, dan Musik
}

FAKULTAS BAHASA DAN SENI

UNIVERSITAS NEGERI SEMARANG

2016 


\section{PERSETUJUAN PEMBIMBING}

Skripsi ini telah disetujui oleh pembimbing untuk diajukan ke sidang Panitia Ujian Skripsi Jurusan Pendidikan Seni Drama, Tari, dan Musik Fakultas Bahasa dan Seni Universitas Negeri Semarang dengan judul "STRATEGI DAN INOVASI PEMBELAJARAN INTRAKURIKULER SENI MUSIK DI SMP NEGERI 34 SEMARANG "

Semarang, 21 September 2016

Pembimbing I

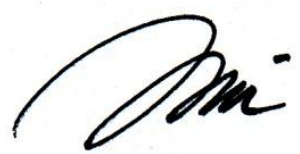

Dr. Wadiyo, M.Si.

NIP.1959123019880300
Pembimbing II

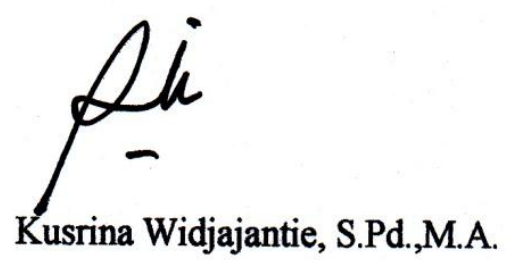

NIP. 197218052005012001 


\section{PENGESAHAN KELULUSAN}

Skripsi ini telah dipertahankan di hadapan sidang Panitian Ujian Skripsi Jurusan Pendidikan Sendratasik, Fakultas Bahasa dan Seni, Universitas Negeri Semarang.

$$
\begin{array}{ll}
\text { Pada hari } & : \text { Rabu } \\
\text { Tanggal } & : 2 \text { November } 2016
\end{array}
$$

Panitia Ujian Skripsi

Prof. Dr. Agus Nuryatin, M.Hum. (196008031989011001)

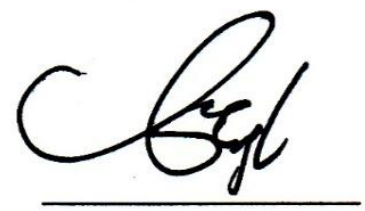

Ketua

Dr. Udi Utomo, M.Si. (196708311993011001)

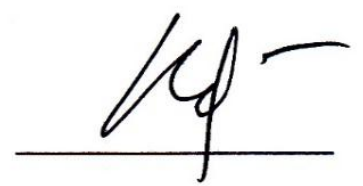

\section{Sekretaris}

Drs. Moh Muttaqin, M.Hum. (196504251992031001)

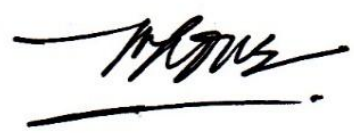

Penguji I

Kusrina Widjajantie, S.Pd.,M.A. (197218052005012001)

Penguji II/Pembimbing II

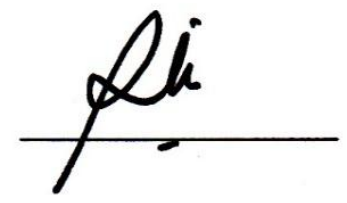

Dr. Wadiyo, M.Si. (19591230198803001)

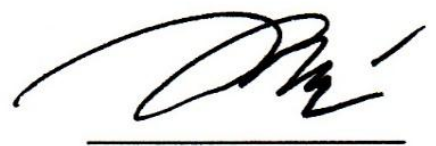

Penguji III/Pembinbing I

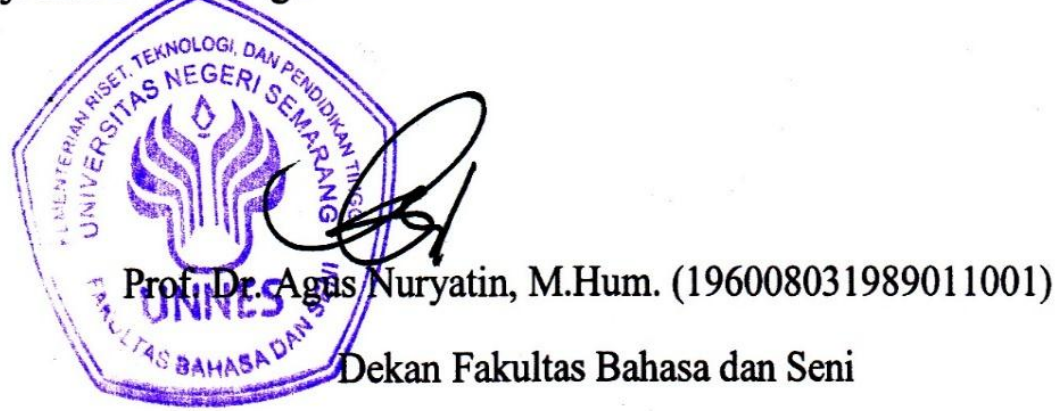




\section{PERNYATAAN}

Saya menyatakan bahwa yang tertulis didalam skripsi yang berjudul

\section{STRATEGI DAN INOVASI PEMBELAJARAN SENI MUSIK DI SMP}

NEGERI 34 SEMARANG benar-benar hasil karya saya sendiri bukan jiplakan dari karya orang lain baik sebagian atau seluruhnya. Pendapat atau temuan orang lain yang terdapat dalam skripsi ini dikutip atau dirajuk berdasarkan kode etik ilmiah.

Semarang, 21 September 2016

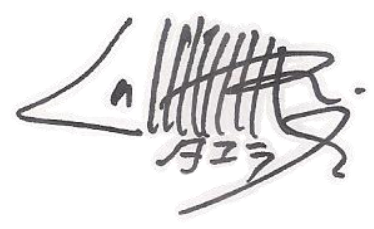

Ahadiah Ana Tamala

NIM 2501411008 


\section{MOTTO DAN PERSEMBAHAN}

\section{Motto :}

1. Ruku'lah kamu, sujudlah kamu, sembahlah Tuhanmu dan perbuatlah kebajikan, supaya kamu mendapatkan kemenangan (Q.S. Al-Hajj (22): 77)

2. Barang siapa bertakwa kepada Allah niscahya Allah menjadikan baginya kemudahan dalam segala urusannya (Q.S. Ath-Thalaq :4)

3. Anda harus melalui hari ini dengan irama. Biarkan seluruh kehidupanmu berirama seperti lagu. (Sai Baba)

\section{Persembahan}

Skripsi ini saya persembahkan untuk:

1. Bapak dan Ibuku tercinta Bapak Sukandar dan Ibu Inayati, S.Pd. yang tak pernah berhenti mendoakan dan memberi motivasi kepada saya, yang telah mengajarkan untuk tidak mudah menyerah, sabar dan selalu optimis dalam segala hal apapun.

2. Sahabat dan teman-temanku dari SMA dan dari pendidikan seni musik angkatan 2011 yang selalu memberikan semangat dan dukungan.

3. Almamaterku, Universitas Negeri Semarang. 


\section{SARI}

Tamala, Ahadiah Ana. 2016, Strategi dan Inovasi Pembelajaran Seni Musik Di SMP Negeri 34 Semarang. Skripsi. Jurusan Pendidikan Sendratasik. Fakultas Bahasa dan Seni. Universitas Negeri Semarang. Pembimbing I: Dr. Wadiyo, M.Si., Pembimbing II: Kusrina Widjajantie, S.Pd.,M.A

Kata Kunci : Strategi, Inovasi, Pembelajaran, Seni Musik

Kegiatan pembelajaran merupakan kegiatan utama yang diterapkan di sekolah, dalam kegiatan pembelajaran guru memiliki strategi-strategi dan inovasi pembelajaran yang digunakan disetiap melakukan proses kegiatan belajar mengajar di dalam kelas, dan mematahkan persepsi para siswa tentang pelajaran seni budaya khususnya seni musik bukanlah mata pelajaran yang boleh untuk dinomor duakan dari mata pelajaran umum yang lain. Masalah yang diangkat dalam penelitian ini adalah Strategi dan Inovasi Pembelajaran Seni Musik di SMP Negeri 34 Semarang.

Penelitian ini merupakan penelitian deskriptif kualitatif. Lokasi penelitian bertempat di SMP Negeri 34 Semarang. Sasaran penelitian ini adalah strategi dan inovasi pembelajaran dalam kegiatan belajar mengajar di kelas meliputi strategi pembelajaran yang digunakan guru serta inovasi pembelajaran yang dilakukan guru. Metode penelitian yang diterapkan adalah deskriptif kualitatif. Teknik pengumpulan data menggunakan teknik observasi, wawancara, dan studi dokumen. Keabsahan data menggunakan triangulasi data.

Hasil penelitian mengenai strategi dan inovasi pembelajaran seni musik di SMP Negeri 34 Semarang menunjukan bahwa strategi pembelajaran yang digunakan guru di kelas adalah strategi pengelolaan kegiatan yang meliputi : (1) penyampaian materi, (2) peralatan atau media, dan (3) bahan serta waktu, selain beberapa strategi yang telah digunakan sebelumnya guru juga menggunakan strategi berbasis masalah (SPMB) sebagai metode pembelajaran di dalam kelas, dari strategi terdapat lima komponen yang ikut serta digunakan dalam kegiatan pembelajaran, lima komponen tersebut ialah tujuan pembelajaran, materi pembelajaran, metode, media dan evaluasi. Sedangkan terdapat tiga model inovasi pembelajaran yang digunakan ialah inovasi pembelajaran kuantum, inovasi pembelajaran kompetensi dan inovasi pembelajaran kontekstual.

Simpulan hasil penelitian yakni strategi pembelajaran pengelolaan kegiatan yang bertujuan agar kegiatan beklajar mengajar di dalam kelas lebih terarah dan tujuan digunakannya inovasi pembelajaran adalah agar menciptakan kesan baru untuk para siswa dalam mengikuti kegiatan pembelajaran seni musik. Saran yang disampaikan yakni untuk sekolah agar lebih memperhatikan fasilitas alat-alat musik untuk para siswa, untuk guru lebih mengembangkan strategi pembelajaran yang sudah ada dan menciptakan inovasi-inovasi baru yang lebih menarik. 


\section{KATA PENGANTAR}

Puji syukur penulis panjatkan kepada Allah SWT yang telah memberi kemudahan dan kelancaran dalam menyelesaikan penulisan skripsi yang berjudul Strategi dan Inovasi Pembelajaran Seni Musik di SMP Negeri 34 Semarang.

Skripsi ini dapat selesai berkat bimbingan dan bantuan dari berbagai pihak. Maka dari itu, pada kesempatan ini penulis menyampaikan ucapan terimakasih yang tulus kepada:

1. Prof. Dr. Fatkhur Rokhman, M. Hum., Rektor Universitas Negeri Semarang yang telah memberikan kesempatan pada penulis untuk dapat menimba ilmu di Universitas Negeri Semarang.

2. Prof. Dr. Agus Nuryatin, M.Hum., Dekan Fakultas Bahasa dan Seni Universitas Negeri Semarang yang telah memberikan izin penelitian kepada penulis.

3. Dr. Udi Utomo, M.Si, Ketua Jurusan Sendratasik yang memudahkan jalan penulisan dalam menyusun skripsi.

4. Dr. Wadiyo, M.Si. dan Kusrina Widjajantie, S.Pd.,M.A. sebagai dosen pembimbing yang dengan penuh kesabaran telah memberi arahan, bimbingan, dan saran sehingga skripsi ini dapat terselesaikan dengan baik.

5. Bapak dan Ibu Dosen Program Studi Pendidikan Seni Musik yang telah memberikan bekal ilmu pengetahuan sehingga penulis dapat menyelesaikan studi dan penulisan skripsi.

6. Kepala sekolah Sutadi S.Pd., M.Pd. SMP Negeri 34 Semarang yang telah memberikan izin penelitian dan bantuannya kepada penulis. 
7. Ibu Theresia Farida Dharmawati, sebagai guru pengampu Seni Budaya di SMP Negeri 34 Semarang yang telah mengijinkan penulis untuk meneliti dan memberikan informasi-informasi yang dibutuhkan oleh penulis.

8. Rekan-rekan mahasiswa program studi pendidikan seni drama tari dan musik (seni musik 2011) yang telah banyak memberikan masukan kepada penulis baik selama dalam mengikuti perkuliahan maupun dalam penulisan skripsi ini.

9. Ibunda dan ayahanda serta adikku Riqi yang sangat banyak memberikan bantuan moril, material, arahan, dan selalu mendoakan keberhasilan dan keselamatan selama menempuh pendidikan dan Vandy Arizal yang tak henti-hentinya selalu memberi semangat.

10. Semua pihak yang tidak dapat penulis sebutkan satu persatu yang telah membantu dalam penyelesaian penulisan skripsi.

Semoga bantuan, bimbingan dan dukungan yang telah diberikan menjadi amal dan kebaikan yang akan mendapat balasan yang setimpal dari Tuhan. Penulis mengharapkan semoga skripsi ini dapat bermanfaat bagi pembaca, khususnya mahasiswa Jurusan Pendidikan Seni Musik.

Semarang, September 2016

Penulis 


\section{DAFTAR ISI}

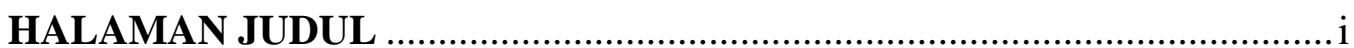

PERSETUJUAN PEMBIMBING _....................................................... ii

PENGESAHAN KELULUSAN ................................................................

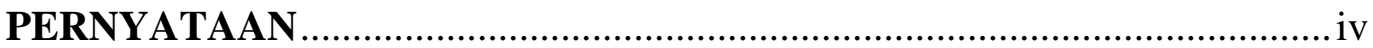

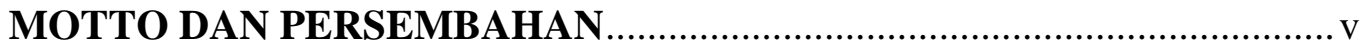

SARI

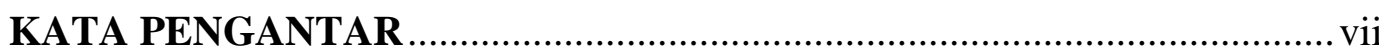

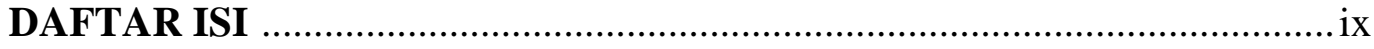

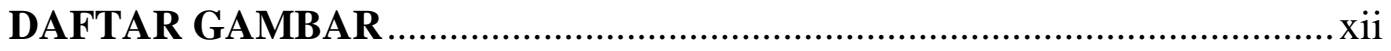

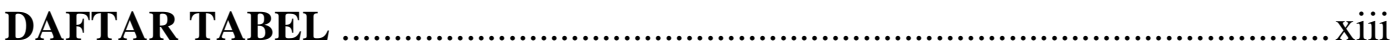

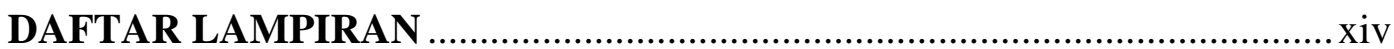

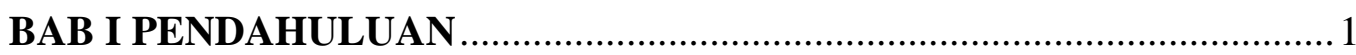

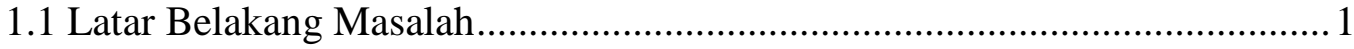

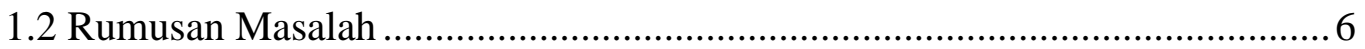

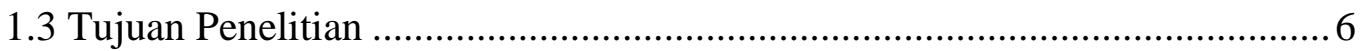

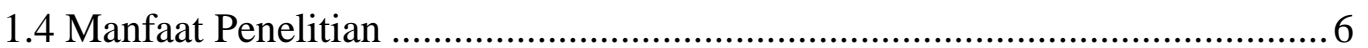

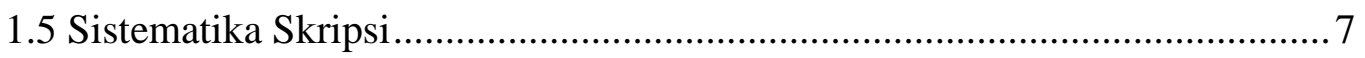

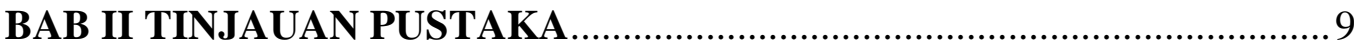

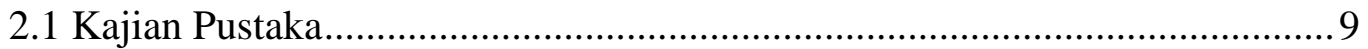

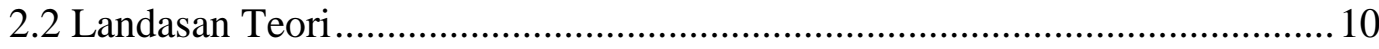

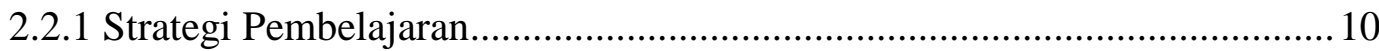




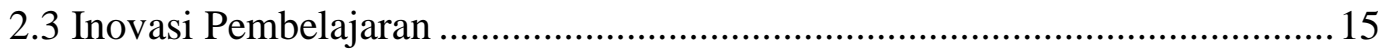

2.3.1 Model-model Inovasi Pembelajaran .................................................... 18

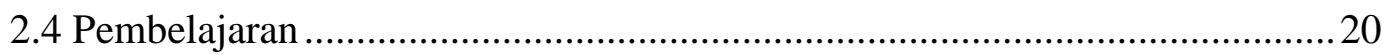

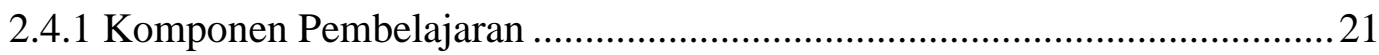

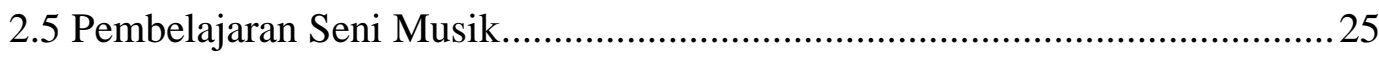

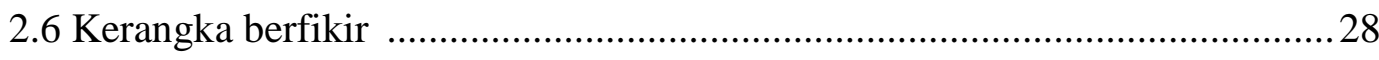

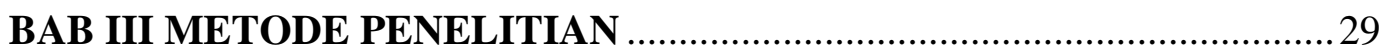

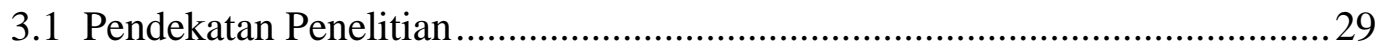

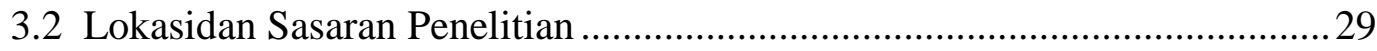

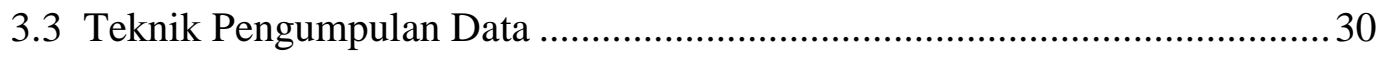

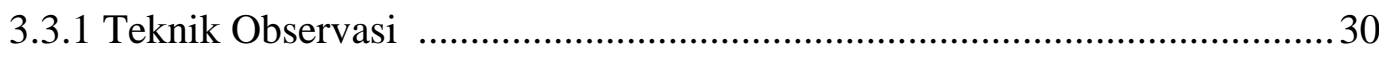

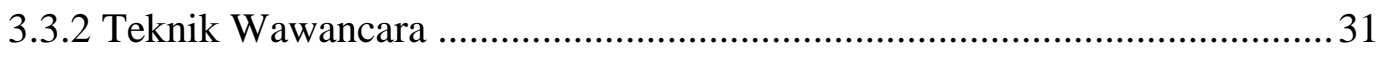

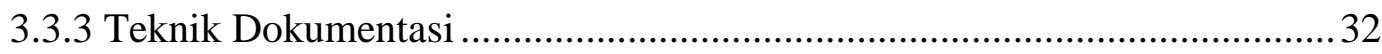

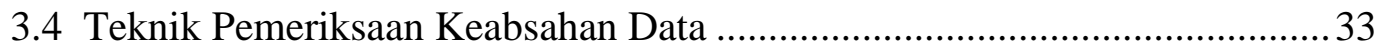

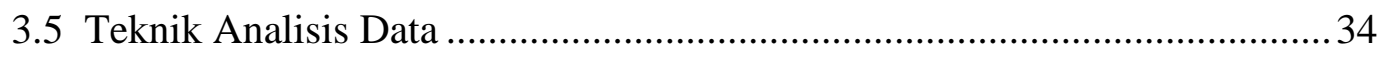

BAB IV HASIL PENELITIAN DAN PEMBAHASAN ............................... 36

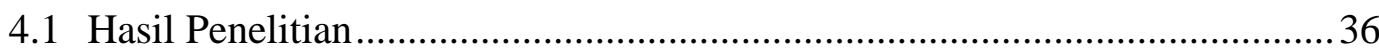

4.1.1 Gambaran Umum dan Sejarah Singkat SMP N 34 Semarang .................... 36

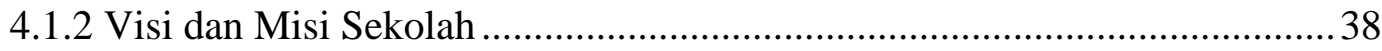

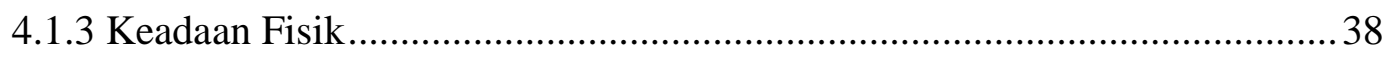

4.1.4 Tenaga Pengajar, Pendukung dan Siswa................................................ 41

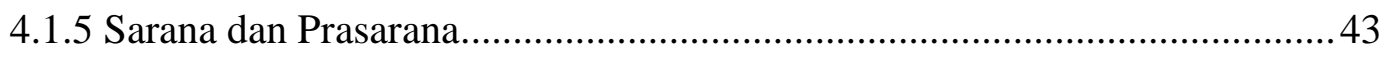




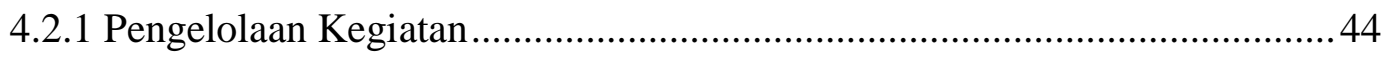

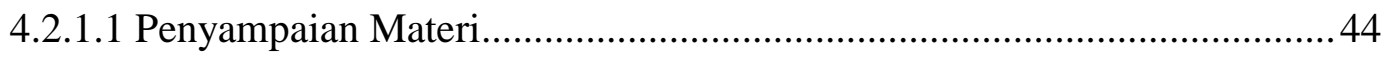

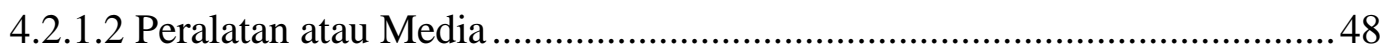

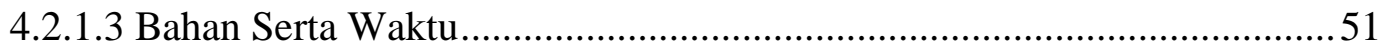

4.2.2 Komponen Pembelajaran Seni Musik di SMP Negeri 34 Semarang ............53

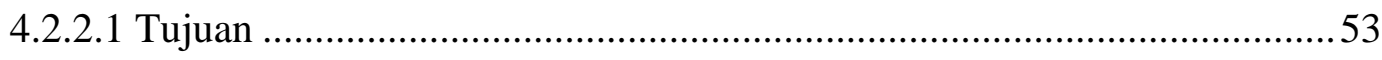

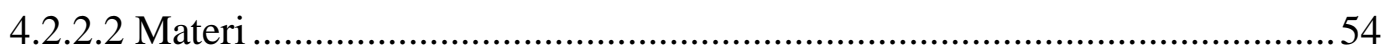

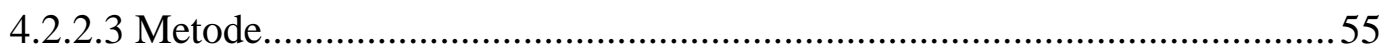

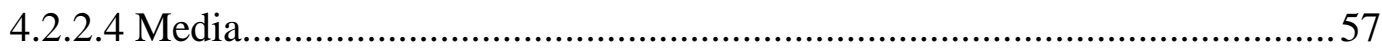

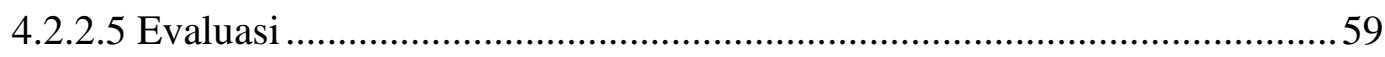

4.3 Inovasi Pembelajaran Seni Musik di SMP Negeri 34 Semarang .................. 60

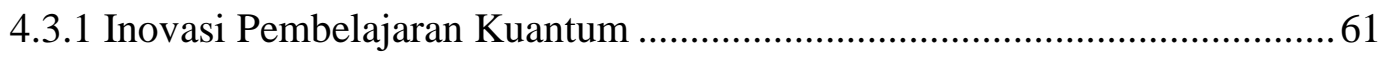

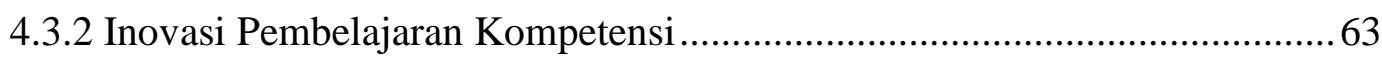

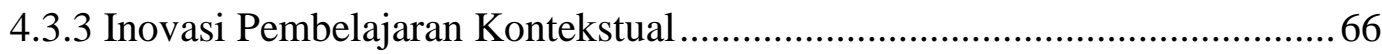

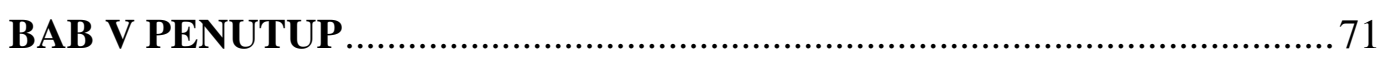

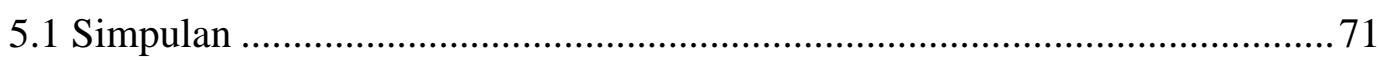

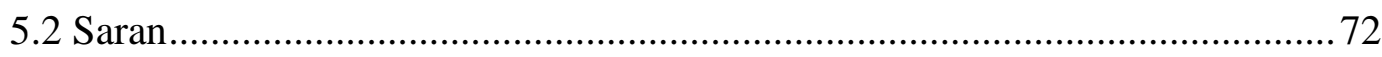

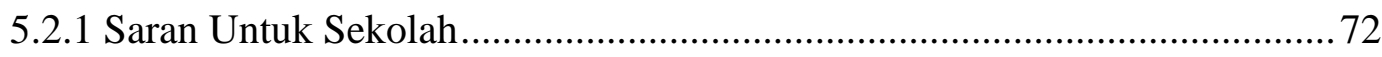

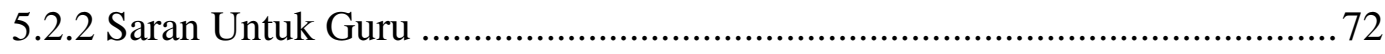

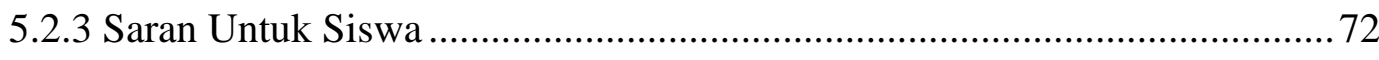

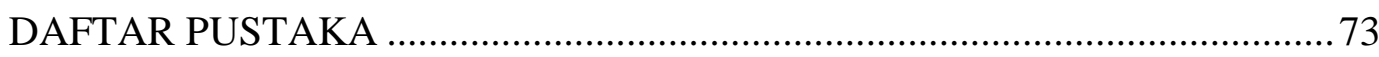

LAMPIRAN-LAMPIRAN 


\section{DAFTAR FOTO}

Halaman

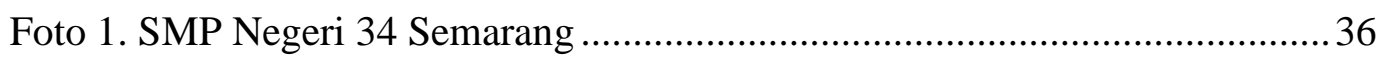

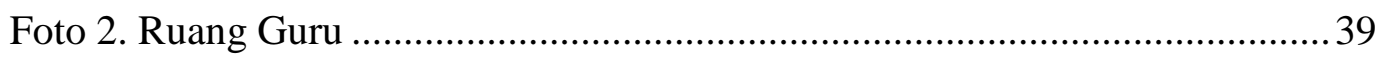

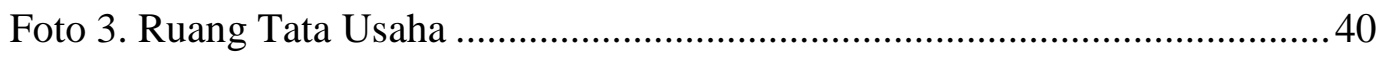

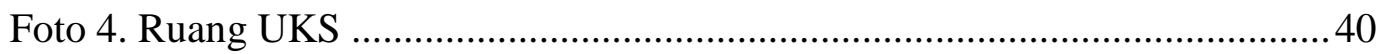

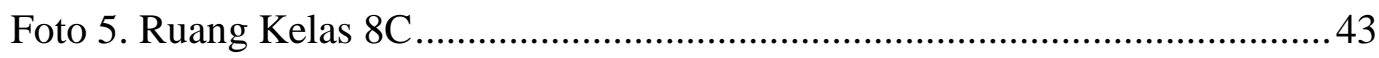

Foto 6. Observasi Awal Sebelum Memulai Penelitian......................................... 46

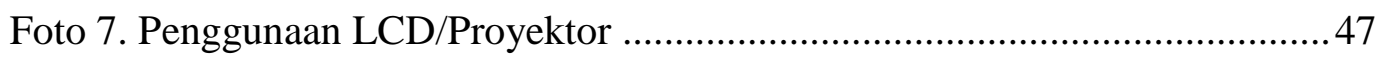

Foto 8. Kegiatan Siswa Praktek Bermain Alat Musik ........................................51

Foto 9. Penggunaan Media Pembelajaran ........................................................59

Foto 10. Kegiatan Siswa Saat Berdiskusi ....................................................... 


\section{DAFTAR TABEL}

Halaman

Tabel 1. Daftar Jumlah Bangunan SMP N 34 Semarang................................... 41

Tabel 2. Daftar Nama dan Jumlah Tenaga Pendidik dan Tenaga Pendukung ...... 41

Tabel 3. Jumlah dan Daftar Nama Siswa Kelas 8c ........................................... 42 


\section{DAFTAR LAMPIRAN}

Halaman

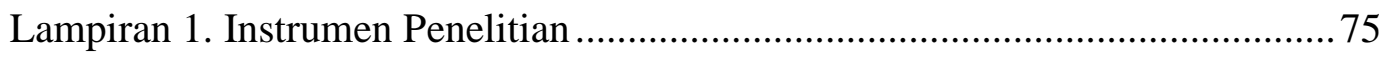

Lampiran 2. Surat Penetapan Dosen Pembimbing............................................ 78

Lampiran 3. Surat Permohonan Penelitian.............................................................. 80

Lampiran 4. Surat Keterangan Telah Melakukan Penelitian di SMP Negeri 34

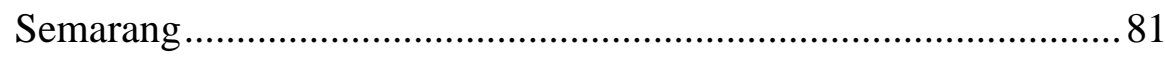

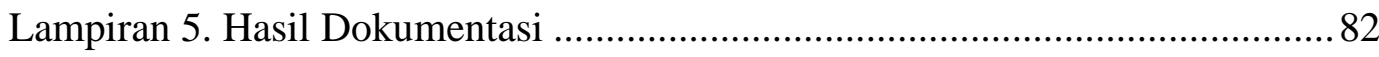

Lampiran 6. Daftar Nama Siswa-siswi Kelas 8C di SMP Negeri 34 Semarang .. 87

Lampiran 7. Partitur Lagu Materi Pembelajaran................................................ 88

Lampiran 8. Daftar Guru SMP Negeri 34 Semarang ......................................... 89

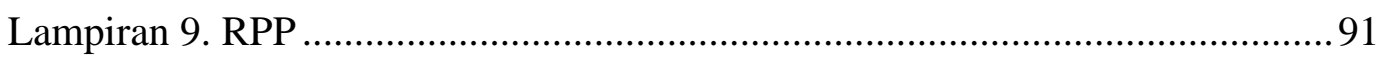

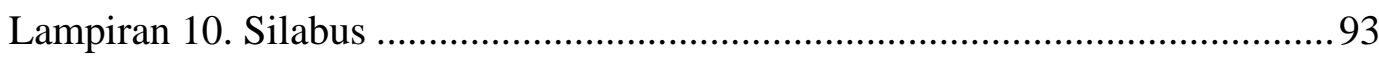




\section{BAB I}

\section{PENDAHULUAN}

\subsection{Latar Belakang Masalah}

Pendidikan seni meliputi semua bentuk kegiatan aktivitas dan cita rasa keindahan. Aktivitas fisik dan cita rasa keindahan itu tertuang dalam kegiatan berekspresi, bereksplorasi, berkreasi dan berapresiasi melalui bahasa rupa, bunyi, gerak dan peran, Balitbang Depdiknas (2001:7). Pendidikan seni juga bertautan dengan pendidikan pribadi, dalam berbagai tautannya sehingga pradigma pendidikan seni mengandung pula tujuan pendidikan keseluruhannya, demikian juga hal itu berlaku untuk pendidikan musik.

Seni musik atau seni suara adalah seni yang diterima melalui indera pendengaran. Rangkaian bunyi yang didengar dapat memberikan rasa indah manusia dalam bentuk konsep pemikiran yang bulat, dalam wujud nada-nada atau bunyi lainnya yang mengandung ritme dan harmoni, serta mempunyai bentuk dalam ruang waktu yang dikenal oleh diri sendiri dan manusia lain dalam lingkungan hidupnya, sehingga dapat dinikmati. Selain itu, musik juga dapat memberi rasa puas bagi yang mendengarkannya karena adanya keserasian susunan dari rangkaian tangga nada bunyi-bunyi tersebut, Bahari (2008: 55).

Menurut Jamalus (1998: 2) pemahaman unsur-unsur musik akan diperoleh melalui pengajaran yang dinamakan teori musik dasar. Pengajaran teori musik dasar ini dapat memberikan pemahaman yang bermakna bagi seseorang jika ia telah mengalami serta menghayati fungsi unsur-unsur musik itu dalam lagu yang 
dipelajarinya, untuk memperoleh pemahaman tersebut, unsur-unsur musik itu haruslah diberikan melalui pengalaman bermusik, yaitu penghayatan suatu lagu melalui kegiatan mendengarkan, bernyanyi, bermain musik, bergerak mengikuti musik, serta membaca musik, sehingga siswa mendapat gambaran menyeluruh tentang ungkapan lagu tersebut.

Undang-undang No. 20 Tahun 2003 tentang sistem pendidikan Nasional menyatakan bahwa pendidikan adalah usaha sadar dan terencana untuk mewujudkan suasana belajar dan proses pembelajaran agar peserta didik secara aktif mengembangkan potensi dirinya untuk memiliki kekuatana spiritual keagamaan, pengendalian diri, kepribadian, kecerdasan, akhlak mulia, serta keterampilan yang diperlukan dirinya, masyarakat, bangsa, dan Negara, (dalam Sanjaya, 2006:2).

Menurut Edgar Dale (dalam Sukarman, 2003:16) metode yang menarik untuk siswa adalah pengalaman langsung ( cone of experience ). Pengalaman dalam ruangan (Indoor) maupun luar ruangan (outdoor) dan tidak meninggalkan karakteristik mata pelajaran. Maka berdasarkan pernyataan tersebut, upaya mengemas proses pembelajaran yang mengajak siswa untuk berinteraksi aktif dalam mata pelajaran seni musik, menjadi tantangan bagi kalangan pendidik, khususnya guru musik itu sendiri. Guru sebagai mediator dalam proses pembelajaran musik dituntut mampu menguasai materi yang diajarkan, mampu menggunakan metode yang tepat, mampu menggunakan langkah-langkah yang tepat dalam pembelajaran musik, mampu menggunakan media atau alat peraga 
sesuai pokok bahasan, mampu mengelola kelas serta dapat menggunakan waktu yang tersedia dengan tepat.

Dalam sistem pembelajaran tujuan merupakan komponen yang utama. Segala aktivitas guru dan siswa, mestilah diupayakan untuk mencapai tujuan yang telah ditentukan. Penerapan strategi yang tepat dalam sebuah pembelajaran, akan menghasilkan tujuan dalam pembelajaran yang diinginkan. Tujuan pembelajaran adalah perilaku hasil belajar yang diharapkan terjadi, dimiliki atau dikuasai oleh peserta didik setelah mengikuti kegiatan pembelajaran tertentu. Penyusunan tujuan pembelajaran merupakan tahapan penting dalam rangkaian pengembangan desain pembelajaran. Dari tahap ini ditentukan apa dan bagaimana harus melakukan tahap lainnya, apa yang dirumuskan dalam tujuan pembelajaran menjadi acuan untuk menentukan jenis materi pembelajaran, strategi pembelajaran, metode pembelajaran, dan media pembelajaran yang akan digunakan dalam proses pembelajaran. Tanpa tujuan dan strategi yang jelas, pembelajaran akan menjadi kegiatan tanpa arah, tanpa fokus dan menjadi tidak efektif.

Inovasi pendidikan adalah suatu perubahan yang baru, dan kualitatif berada dari hal (yang ada sebelumnya), serta sengaja diusahakan untuk meningkatkan kemampuan guna mencapai tujuan tertentu dalam pendidikan, Syaefudin (2009:6). Inovasi pembelajaran menurut bahasa terdiri dari dua kata yakni kata inovasi dan kata pembelajaran. Inovasi memiliki arti pembaruan sedangkan pembelajaran memiliki arti sebuah kegiatan penyampaian ilmu pengetahuan dari seseorang tenaga pendidik kepada para peserta didiknya. 
Sehingga dapat diambil kesimpulan bahwa inovasi pembelajaran merupakan sebuah pembaharuan terhadap berbagai komponen yang diperlukan dalam penyampaian materi pembelajaran berupa ilmu pengetahuan dari tenaga pendidik kepada para peserta didik dengan tujuan untuk meningkatkan kualitas pendidikan yang berlangsung.

Inovasi pembelajaran diperlukan agar siswa dapat menguasai materi pelajaran seni musik dengan baik dan benar dan untuk memperoleh hal yang lebih baik dalam bidang pendidikan. Model pembelajaran yang inovative tentu tidak mengesampingkan trend pada masa tertentu, karena dimensi apresiasi seni anak cenderung berubah menurut usianya, Mack (2002:64). Semakin guru bisa memahami trend musik anak, perhatian dan motivasi anak juga semakin bertambah. Walaupun ini bukan utama, namun bisa menjadi daya tarik tersendiri di samping meletakkan dasar-dasar musik. Dengan demikian, guru harus mampu membimbing, memimpin dan menciptakan situasi yang baik bagi siswa, gurupun harus mampu memahami isi jiwa, sifat, mental setiap siswa dan juga harus mampu memanfaatkan media pembelajaran dengan baik agar dapat memberikan bimbingan dan pembelajaran yang sebaik-baiknya.

Pembelajaran musik di sekolah khususnya ditingkat SMP berdasarkan PERMEN 22 tahun 2006 tentang STANDAR ISI, dinyatakan bahwa :

Pendidikan seni musik merupakan bagian dari pendidikan mata pelajaran seni budaya, yang memiliki beberapa tujuan, antara lain sebagai berikut: (1) Memahami konsep dan pentingnya seni budaya ; (2) Menampilkan sikap apresiasi terhadap seni budaya; (3) Menampilkan kreatifitas melalui seni budaya; (4) 
Menampilkan peran serta dalam seni budaya dalam tingkat lokal, regional maupun global.

Selama ini kegiatan pembelajaran seni musik di SMP Negeri 34 Semarang belum begitu diminati siswa, hal ini dikarenakan materi yang disampaikan oleh guru kurang begitu menarik bagi siswa. Agar proses pembelajaran berlangsung dengan baik, maka hendaknya guru memberikan materi pelajaran secara bervariasi, dapat menggunakan strategi atau metode pembelajaran yang tepat. Menurut Sanjaya (2010:126). Berdasarkan observasi yang dilakukan penulis pada saat melakukan PPL pada tahun 2014, penulis melihat bahwa pada saat berlangsungnya kegiatan pembelajaran seni budaya di kelas masih banyak siswa yang perhatiannya kurang pada guru yang sedang mengajar di depan kelas, terdapat beberapa siswa yang berbicara dengan teman sebangkunya, ada juga yang asik sendiri dan tidak memeperhatikan guru pada saat menerangkan. Pada saat guru melempar beberapa pertanyaan kepada siswa, masih banyak siswa yang tidak aktif menjawab dan bahkan tidak paham dengan apa yang ditanyakan oleh guru.

Hal ini yang menyebabkan penulis ingin meneliti untuk mengetahui bagaimana strategi dan inovasi yang harusnya diterapkan agar dapat meningkatkan minat siswa terhadap pelajaran seni budaya khususnya seni musik. Jadi menurut siswa selama ini pembelajaran seni musik itu sendiri bukan pelajaran yang begitu harus diperhatikan. Padahal semua mata pelajaran haruslah sama pentingnya.

Dalam penelitian ini penulis melakukan penelitian pada kelas $8 \mathrm{C}$, karena pertimbangan kepala sekolah dan guru pengampu mengarahkan penulis untuk 
meneliti di kelas 8C, di dalam kelas tersebut menurut guru yang paling sulit untuk dikendalikan. Berdasarkan latar belakang tersebut, peneliti tertarik untuk melakukan penelitian dengan judul "Strategi dan inovasi pembelajaran seni musik di SMP Negeri 34 Semarang”

\subsection{Rumusan Masalah}

Berdasarkan latar belakang tersebut, dapat dirumuskan suatu permasalahan sebagai berikut

1.2.1 Bagaimana strategi pembelajaran seni musik di SMP N 34 Semarang ?

1.2.2 Bagaimana inovasi pembelajaran seni musik di SMP N 34 Semarang ?

\subsection{Tujuan Penelitian}

Berdasarkan rumusan masalah tersebut, tujuan penelitian ini secara khusus adalah untuk :

1.3.1 Mengetahui strategi pembelajaran seni musik di SMP N 34 Semarang.

1.3.2 Mengetahui inovasi pembelajaran seni musik di SMP N 34 Semarang.

\subsection{Manfaat Penelitian}

Berdasarkan tujuan penelitian tersebut, diharapkan penelitian ini dapat bermanfaat untuk :

\subsubsection{Manfaat Teoritis}

Hasil penelitian ini dapat dimanfaatkan untuk mengembangkan teori strategi dan inovasi pembelajaran yang telah ada, sehingga dapat dimanfaatkan pada pembelajaran di sekolah SMP N 34 Semarang.

\subsubsection{Manfaat Praktis}

\subsubsection{Bagi Siswa}


Bagi siswa, skripsi ini dapat memudahkan dalam pembelajaran seni musik yang diajarkan oleh guru.

\subsubsection{Bagi Guru}

Bagi guru, skripsi ini dapat menambah wawasan pengetahuan dalam bidang pendidikan untuk meningkatkan profesionalitas, terutama dalam memberikan strategi dan inovasi pembelajaran di kelas.

\subsubsection{Bagi Sekolah}

Bagi sekolah skripsi ini memberikan input kepada sekolah untuk dapat menyediakan sarana prasarana guna mencapai pembelajaran yang lebih baik.

\subsection{Sistematika Skripsi}

Untuk memahami jalan pikiran secara keseluruhan, penulisan skripsi ini terbagai menjadi 3 bagian yaitu:

1.5.1 Bagian awal skripsi yang berisi judul skripsi, halaman persetujuan halaman pengesahan, halaman motto, kata pengantar, daftar isi, dan sari.

\subsubsection{Bagian isi terdiri atas}

Bab 1 pendahuluan, Bab ini memuat tentang (a) Latar Belakang Masalah, (b) Rumusan Masalah, (c) Tujuan Penelitian, (d) Manfat Penelitian, (e) Sistematika Skripsi

Bab 2 tinjauan pustaka dan landasan teori, Bab ini berisikan landasan teori yang relevan dengan permasalahan peneliti dalam skripsi. Di dalam landasan teori ini akan diuraikan mengenai teori-teori tentang pengertian strategi pembelajaran, 
pengertian inovasi, pengertian inovasi pembelajaran, komponen-komponen pembelajaran, pengertian pembelajaran seni musik.

Bab 3 metode penelitian. Bab ini berisi tentang cara-cara yang dilakukan peneliti dalam melakukan research yakni : Pendekatan Penelitian, Lokasi dan Sasaran Penelitian, Teknik Pengumpulan Data, Teknik Dokumentasi, Teknik Pemeriksaan Keabsahan Data, Teknik Analisis Data.

Bab 4 hasil peneltian, dan pembahasan, Bab ini berisikan deskripsi gambaran umum, hasil penelitian, dan Pembahasan.

Bab 5 penutup, Bab ini berisikan Simpulan dan Saran.

1.5.3 Bagian akhir skripsi berisikan daftar pustaka dan lampiran-lampiran. 


\section{BAB II}

\section{TINJAUAN PUSTAKA}

\subsection{Kajian Pustaka}

Khaerul Zaelani (2014) dalam skripsinya yang berjudul "Strategi Pembelajaran Seni Musik Di SMP Negeri 12 Yogyakarta”, membahas tentang pengertian pembelajaran, pembelajaran seni musik strategi guru yang digunakan dalam pembelajaran di sekolah tersebut, komponen-komponen strategi. Dengan demikian obyek yang dibahas dalam penelitian Khaerul (2014), walaupun bertopik sama yaitu mengenai strategi pembelajaran seni musik di sekolah tetapi sedikit berbeda di obyek yang diteliti dan lokasi penelitian yaitu Strategi dan Inovasi Pembelajaran Seni Musik Di SMP Negrei 34 Semarang.

Ratna Luhung Strinariswari (2015) dalam skripsinya yang berjudul "Strategi Pembelajaran Ekstrakurikuler Paduan Suara Di SMP Negeri 2 Jepara" membahas tentang strategi guru/pelatih dalam mengajarkan ekstrakurikuler paduan suara di SMP Negeri 2 Jepara meskipun objek pembahasan dalam penelitian Ratna (2015) sama yaitu mengenai strategi pembelajaran, namun fokus yang dibahas berbeda dengan penelitian yang akan dilaksanakan yaitu tentang Strategi dan Inovasi Pembelajaran Seni Musik Di SMP Negrei 34 Semarang.

Nurul Arifah (2013) dalam skripsinya yang berjudul “ Implementasi Pembelajaran Aktif, Inovatif, Kreatif, Efektif dan Menyenangkan (PAIKEM) Dalam Pembelajaran Aqidah Akhlak Kelas IV A Di MI N Tempel Ngaglik Sleman" membahas tentang pengertian PAIKEM, Konsep PAIKEM, Prinsip Paikem dan strategi PAIKEM dalam pembelajaran Aqidah Akhlak. Walaupun 
topik dalam penelitian Nurul (2013) hampir memiliki tema yang sama dengan pokok pembahasan yang akan dilaksanakan dalam penelitian ini, tetapi fokus yang diteliti sangat berbeda dengan penelitian yang akan dilaksanakan dalam penelitian ini yaitu tentang Strategi dan Inovasi Pembelajaran Seni Musik Di SMP Negrei 34 Semarang.

Dari beberapa hasil penelitian di atas menunjukkan bahwa topik penelitian mengenai Strategi dan Inovasi Pembelajaran Seni Musik Di SMP Negrei 34 Semarang masih orisinil, atau tidak tumpang-tindih dengan hasil-hasil penelitian terdahulu.

\subsection{Landasan Teori}

\subsubsection{Strategi Pembelajaran}

Strategi pembelajaran merupakan suatu rencana, cara pandang dan pola pikir guru dalam mengorganisasikan isi pelajaran, penyampaian pelajaran, dan pengelolaan kegiatan belajar mengajar untuk mencapai tujuan pembelajaran. Dalam strategi pembelajaran, terkandung makna perencanaan. Artinya, strategi pada dasarnya masih bersifat konseptual tentang keputusan-keputusan yang akan diambil dalam suatu pelaksanaan pembelajaran. (Khanifatul, 2014:15)

Strategi merupakan pola umum rentetan kegiatan yang harus dilakukan untuk mencapai tujuan. Dalam pembelajaran perlu strategi agar tujuan tercapai dengan optimal. Cara yang ditetapkan sebagai hasil kajian strategi dalam proses pembelajaran dinamakan metode. Strategi adalah pendekatan secara keseluruhan yang berkaitan dengan pelaksanaan gagasan, perencanaan, dan eksekusi sebuah aktifitas dalam kurun waktu tertentu (Wikipedia, 2008:1). 
Strategi pembelajaran merupakan pendekatan dalam mengelola kegiatan, dengan mengintregasikan urutan kegiatan, cara mengorganisasikan materi pelajaran dan pembelajaran, peralatan dan bahan serta waktu yang digunakan dalam proses pembelajaran, untuk mencapai tujuan pembelajaran yang telah ditentukan, secara efektif dan efisien (Hamdani, 2011:24).Strategi di artikan sebagai keseluruhan keputusan kondisional yang menetapkan tindakan yang harus di jalankan guna menghadapi setiap keadaan yang mungkin terjadi di masa depan (Setiawan, 2006:2).

Dapat ditarik kesimpulan dari beberapa sumber seperti Khanifatul, Hamdani dan Setiawan bahwa strategi pembelajaran adalah perencanaan atau kebijakan yang dirancang di dalam mengelola pembelajaran untuk mencapai tujuan pembelajaran yang diinginkan.

\subsubsection{Macam-macam Strategi Pembelajaran yang dapat digunakan}

Menurut Sanjaya (2006:177-274) ada beberapa strategi pembelajaran yang dapat digunakan, adalah sebagai berikut :

\subsubsection{Strategi Pembelajaran Ekspositori (SPE)}

Strategi pembelajaran ekspositori adalah strategi pembelajaran yang menekankan kepada proses penyampaian materi secara verbal dari seorang guru kepada sekelompok siswa dengan maksud agar siswa dapat menguasai materi pelajaran secara optimal.

\subsubsection{Strategi Pembelajaran Inkuiri (SPI)}

Strategi pembelajaran inkuiri adalah rangkaian kegiatan pembelajaran yang menekankan pada proses berpikir secara kritis dan analitis untuk mencari 
dan menemukan sendiri jawaban dari suatu masalah yang dipertanyakan.

\subsubsection{Strategi Pembelajara Berbasis Masalah (SPBM)}

SPBM dapat diartikan sebagai rangkaian aktivitas pembelajaran yang menekankan kepada proses penyelesaian masalah yang dihadapi secara ilmiah. Ciri utama dari SPBM, merupakan rangkaian aktivitas pembelajaran, artinya dalam implementasi SPBM ada sejumlah kegiatan yang harus dilakukan siswa. SPBM tidak mengharapkan siswa hanya sekedar mendengarkan, mencatat, kemudian menghafal materi pelajaran, akan tetapi melalui SPMB siswa aktif berpikir, berkomunikasi, mencari dan mengolah data, dan akhirnya menyimpulkan.

\subsubsection{Strategi Pembelajaran Peningkatan Kemampuan Berfikir (SPPKB)}

Model strategi pembelajaran peningkatan kemampuan berfikir (SPPKB) adalah model pembelajaran yang bertumpu kepada pengembangan kemampuan berfikir siswa melalui telaah fakta-fakta atau pengalaman anak sebagai bahan untuk memecahkan masalah yang diajukan.

\subsubsection{Strategi Pembelajaran Kooperatif (SPK)}

Pembelajaran kooperatif merupakan model pembelajaran dengan menggunakan sistem pengelompokan/tim kecil, yaitu antara empat sampai enam orang yang mempunyai latar belakang kemampuan akademik, jenis kelamin, ras, atau suku yang berbeda (heterogen). Sistem penilaian dilakukan terhadap kelompok. Setiap kelompok akan memperoleh penghargaan, jika kelompok mampu menunjukan prestasi yang dipersyaratkan. 


\subsubsection{Strategi Pembelajaran Kontekstual (CTL)}

Contextual Teaching Learning (CTL) adalah suatu strategi pembelajaran yang menekankan kepada proses keterlibatan siswa secara penuh untuk menemukan materi yang dipelajari dan menghubungkannya dengan situasi kehidupan nyata sehingga mendorong siswa untuk dapat menerapkannya dalam kehidupan mereka.

\subsubsection{Strategi Pembelajaran Afektif}

Strategi pembelajaran afektif memamg berbeda dengan strategi pembelajaran kognitif dan keterampilan. Afektif berhubungan dengan nilai (value), yang sulit diukur, oleh karena menyangkut kesadaran seseorang yang tumbuh dari dalam. Dalam batas tertentu memang afeksi dapat muncul dalam kejadian behavioral, akan tetapi penilaiannya untuk sampai pada kesimpulan yang bisa dipertanggung jawabkan membutuhkan ketelitian dan observasi yang terus menerus, dan hal ini tidaklah mudah untuk dilakukan, apalagi menilai perubahan sikap sebagai akibat dari proses pembelajaran yang dilakukan guru di sekolah.

\subsubsection{Komponen-komponen Strategi Pembelajaran.}

Menurut Uno (2009:3), mengutip pandangan Dick and Carey menyebutkan bahwa terdapat lima komponen strategi pembelajaran, yaitu:

\subsubsection{Pendahuluan}

Menurut Uno (2009:9), Kegiatan pendahuluan yang disampaikan dengan menarik akan dapat meningkatkan motivasi belajar siswa. Pada bagian ini guru diharapkan dapat menarik minat siswa atas materi pelajaran yang akan disampaikan. Secara spesifik, kegiatan belajar pendahuluan menjelaskan tujuan 
pembelajaran khusus yang diharapkan dapat dicapai semua siswa diakhir kegiatan pembelajaran. Dengan demikian, siswa akan menyadari pengetahuan, keterampilan, sekaligus manfaat yang akan diperoleh setelah memelajari pokok bahasan tersebut.

\subsubsection{Penyampaian Materi}

Penyampaian informasi seringkali dianggap sebagai suatu kegiatan yang paling penting dalam proses pembelajaran, padahal bagian ini hanya merupakan salah satu komponen dari strategi pembelajaran. Artinya tanpa adanya kegiatan pendahuluan yang menarik atau dapat memotivasi siswa dalam belajar maka kegiatan penyampaian informasi ini menjadi tidak berarti.

Beberapa hal yang perlu diperhatikan dalam penyampaian informasi adalah urutan, ruang lingkup materi, dan jenis materi. Urutan penyampaian materi pelajaran harus menggunakan pola yang tepat. Urutan penyampaian informasi yang sistematis akan memudahkan siswa cepat memahami apa yang ingin disampaikan oleh gurunya (Uno, 2009: 5). Ruang lingkup materi atau besar kecilnya materi yang akan disampaikan, bergantung pada karakteristik siswa dan jenis materi yang dipelajari. Oleh karena itu, dalam menentukan strategi pembelajaran, guru harus terlebih dahulu memahami jenis materi pelajaran yang akan disampaikan agar diperoleh strategi pembelajaran yang sesuai. Sedangkan menurut Bandura dalam Muhibin (2011:112), dalam tahapan ini guru harus dapat memberikan informasi (materi pelajaran) dengan memberikan contoh sesuai materi pelajaran sehingga siswa dapat lebih baik dalam menangkap dan segala informasi yang disampaikan. 


\subsubsection{Partisipasi siswa}

Berdasarkan prinsip student centered, siswa merupakan pusat dari suatu kegiatan belajar. Hal ini dikenal dengan istilah CBSA (cara belajar siswa aktif) yang diterjemahkan dari SAL (student active training), yang maknanya adalah bahwa proses pembelajaran akan lebih berhasil apabila siswa secara aktif melakukan latian secara langsung dan relevan dengan tujuan pembelajaran yang sudah ditetapkan (Dick dan Carey dalam Uno, 2009:10). Dengan begitu, peran guru dituntut untuk dapat mengajak siswa dengan memberi motivasi agar para siswa dapat berpartisipasi dalam mengikuti suatu proses pembelajaran dengan baik.

\subsubsection{Evaluasi}

Evaluasi atau dikenal dengan istilah follow up adalah suatu hasil kegiatan yang telah dilakukan tetapi seringkali tidak dilaksanakan dengan baik oleh guru Uno, 2009:7). Hal tersebut dikarenakan pada kenyataannya, setiap kali setelah kegiatan pembelajaran dilakukan selalu saja terdapat siswa yang berhasil dangan baik atau di atas rata-rata dan siswa tersebut seharusnya menerima tindak lanjut yang berbeda sebagai konsekuensi dari hasil belajar yang bervariasi tersebut, tetapi guru seringkali melupakannya.

\subsection{Inovasi Pembelajaran}

Inovasi atau pembaharuan diperlukan bukan saja dalam bidang teknologi, tetapi juga di segala bidang pendidikan. Pembaharuan pendidikan diterapkan di dalam berbagai jenjang pendidikan juga dalam setiap komponen sistem 
pendidikan. Sebagai pendidik, kita harus mengetahui dan menerapkan inovasi agar dapat mengembangkan proses pembelajaran yang kondusif sehingga dapat diperoleh hasil yang maksimal.

Inovasi adalah suatu ide, barang, kejadian, metode yang dirasakan atau diamati sebagai suatu hal yang baru bagi seseorang atau sekelompok orang atau masyarakat. Dewasa ini menjadi perbincangan hangat diberbagai kalangan, mulai dari guru, praktisi pendidikan dan pemerintahan daerah. Inovatif yang berati pembaruan (Thompson dan Eveland ; 1967). Menurut Zalman dan Ducan (1977:12) dalam Ibrahim (1988:40) inovasi adalah perubahan sosial yang digunakan untuk mencapai tujuan tertentu dan diamati sebagai suatu yang baru bagi sekelompok orang. Tetapi perubahan sosial belum tentu inovasi.

Inovasi merupakan pemikiran cemerlang yang bercirikan hal baru ataupun berupa praktik-praktik tertentu ataupun berupa produk dari suatu hasil oleh piker dan olah teknologi yang diterapkan melalui tahapan tertentu yang diyakini dan dimaksudkan untuk memecahkan persoalan yang timbul dan memperbaiki suatu keadaan tertentu ataupun proses tertentu yang terjadi di masyarakat, Daryanto dan Mulyo Rahardjo (2012:178). Everett M. Rogers (1983:11) beliau mengemukakan inovasi adalah sebuah gagasan, ide, rencana, praktek atau benda yang diterima dan disadari sebagai sebuah hal yang baru dari seseorang atau kelompok untuk di implementasikan atau diadopsi. Pengertian Inovasi menurut UU No. 18 tahun 2002. Inovasi adalah kegiatan penelitian, pengembangan, dan/atau perekayasaan yang bertujuan mengembangkan penerapan praktis nilai dan konteks ilmu pengetahuan yang baru, atau cara baru untuk menerapkan ilmu pengetahuan dan 
teknologi yang telah ada ke dalam produk atau proses produksi. Dalam penelitian ini yang dimaksud inovasi adalah suatu penemuan baru yang berbeda dari yang sudah ada atau yang sudah dikenal sebelumnya.

Inovasi pendidikan adalah inovasi yang terjadi di bidang pendidikan atau inovasi yang terjadi untuk memecahkan masalah-masalah yang terjadi di bidang pendidikan. Jadi inovasi pendidikan adalah: suatu ide, barang metode, yang dirasakan atau diamati sebagai hal yang baru bagi seseorang atau sekelompok orang (masyarakat) baik berupa hasil invensi atau diskoveri, yang digunakan untuk tujuan pendidikan atau untuk memecahkan masalah pendidikan, Ibrahim $(1988: 51)$

Inovasi pengelolaan pendidikan sebagai kegiatan kreatif penyelenggaraan pendidikan berarti fungsi dan substansi wilayah memiliki unsur kebaharuan. Fungsi dalam pengelolaan misalnya seperti perencanaan kesiswaan memiliki unsur baru. Jika dulu perencanaan kesiswaan tidak melakukan pembentukan panitia penerimaan siswa baru, maka sekarang membentuk panitia yang terdiri atas guru dan komite sekolah serta hasilnya berkeadilan sesuai dengan prinsip manajemen yang baik. Jika dulu tidak ada pemeriksaan pengelolaan keuangan sekolah, sekarang melakukan pemeriksaan internal pengelolaan keungan dan hasilnya bagus. Jika dulu melakukan rapat guru tanpa memberi makanan ringan, sekarang rapat guru dengan memberikan makanan ringan dan menghasilkan keputusan yang diterima semua pihak. Antara fungsi dan substansi dilakukan kreasi, perubahan dari yang dulu, pembaharuan, dan menguntungkan stakeholders (pihak-pihak yang berkepentingan). Stakeholders di sekolah terdiri dari kepala 
sekolah, guru, staf tata usaha, siswa, orang tua siswa, tetangga sekolah, masyarakat sekitar, pemerintah daerah, badan usaha dan sebagainya.

\subsubsection{Model-model Inovasi Pembelajaran}

Menurut Syaefudin (2009: 123-175) ada beberapa model inovasi pembelajaran yang biasa digunakan, sebagai berikut :

\subsubsection{Inovasi Pembelajaran Kuantum}

Inovasi pembelajaran kuantum sebagai salah satu model, strategi, dan pendekatan pembelajaran yang mengkonsentrasikan pada ketrampilan guru dalam mengelola pembelajaran. Konsep, asas, prinsip, dan strategi dari pembelajaran kuantum merupakan aspek-aspek yang harus dipahami oleh guru dalam mengimplementasikan model pembelajaran di sekolah dasar agar konteks dan kontens pembelajaran yang bergairah, menyenangkan dan mempermudah belajar siswa.

\subsubsection{Inovasi Pembelajaran Kompetensi}

Inovasi pembelajaran kompetensi menunjukan pada usaha siswa mempelajari bahan pelajaran sebagai akibat perlakuan guru dalam mengelola pembelajaran yang menekankan pada kemampuan dasar yang dilakukan siswa pada tahap pengetahuan, ketrampilan, dan sikap. Pembelajaran kompetensi menekankan pencapaian standart kompetensi yang diuraikan menjadi kemampuan dasar yang diurai menjadi beberapa materi pelajaran yang cakupannya beberapa indikator. Pembelajaran kompetensi memiliki karakteristik khusus yang berbeda dengan pembelajaran lainnya, seperti apa yang dipelajari siswa bagaimana proses pembelajaran, waktu belajar, dan kemajuan belajar siswa secara individual. 


\subsubsection{Inovasi Pembelajaran Kontekstual}

Inovasi pembelajaran kontekstual merupakan suatu model pembelajaran yang menekankan keterlibatan siswa setiap tahapan pembelajaran dengan cara menghubungkannya dengan situasi kehidupan yang dialami siswa sehari-hari sehingga pemahaman materi diterapakan dalam kehidupan nyata. Karakteristik pembelajaran kontekstual adalah pembelajaran merupakan proses pengaktifan pengetahuan yang sudah ada, belajar dalam rangka memperoleh dan menambah pengetahuan baru, pengetahuan yang diperoleh bukan untuk dihafal tetapi untuk diyakini dan diterapkan, memperaktikan pengalaman dalam kehidupan nyata, dan melakukan refleksi terhadap strategi pengembangan pengetahuan.

Sehingga dapat diambil sebuah kesimpulan bahwa inovasi pembelajaran merupakan sebuah pembaharuan terhadap berbagai komponen yang diperlukan dalam penyampaian materi pembelajaran berupa ilmu pengetahuan dari tenaga pendidik kepada para peserta didik dengan tujuan untuk meningkatkan kualitas pendidikan yang berlangsung. Pembelajaran, merupakan terjemah dari learning yang artinya belajar, atau pembelajaran. Jadi inovasi pembelajaran adalah pembelajaran yang menggunakan ide atau teknik/metode yang baru untuk melakukan langkah-langkah belajar, sehingga memperoleh kemajuan hasil belajar yang diinginkan. Berdasarkan definisi secara harfiah pembelajaran inovatif, terkandung makna pembaruan. Inovasi pembelajaran muncul dari perubahan paradigma pembelajaran. Perubahan paradigm pembelajaran berawal dari hasil refleksi terhadap eksistensi paradigma lama yang mengalami perubahan menuju paradigma baru yang diharapkan mampu memecahkan masalah. Dalam proses 
pembelajaran, paradigma baru pembelajaran sebagai produk inovasi yang lebih menyediakan proses untuk mengembalikan hakikat siswa sebagai manusia yang memiliki segenap potensi untuk mengalami proses dalam mengembangkan kemanusiaannya.

\subsection{Pembelajaran}

Pembelajaran yang diidentikkan dengan kata "mengajar" berasal dari kata dasar "ajar" yang berarti petunjuk yang diberikan kepada orang supaya diketahui (diturut) ditambah dengan awalan "pe" dan akhiran "an" menjadi "pembelajaran", yang berarti proses, perbuatan, cara mengajar atau mengajarkan sehingga anak didik mau belajar.

Pembelajaran adalah suatu usaha untuk membuat peserta didik belajar atau suatu kegiatan untuk membelajarkan peserta didik. Warsita (2008:85) Istilah "pembelajaran" sama dengan "instruction atau "pengajaran". Pengajaran mempunyai arti cara mengajar atau mengerjakan.

UU No. 20 Tahun 2003 tentang sisdiknas Pasal 1 Ayat 20 "Pembelajaran adalah proses interaksi peserta didik dengan pendidik dan sumber belajar pada suatu lingkungan belajar". Pembelajaran adalah kegiatan guru secara terprogram dalam desain instruksional, untuk membuat siswa belajar aktif, yang menekankan pada penyediaan sumber belajar, Dimyati dan Mudjino (1999;297) Menurut Max Darsono dkk (2000 : 24), mendefinisikan pembelajaran sebagai kegiatan yang dilakukan oleh guru sedemikian rupa, sehingga tingkah laku siswa berubah kearah yang lebih baik. 
Pembelajaran merupakan aspek kegiatan manusia yang kompleks, yang tidak sepenuhnya dapat dijelaskan, Trianto $(2010 ; 17)$ Pembelajaran secara sederhana dapat diartikan sebagai produk interaksi berkelanjutan antara pengembang dan hidup. Pembelajaran dalam makna kompleks adalah usaha sadar dari seorang guru untuk membelajarkan siswanya ( mengarahkan interaksi siswa dengan sumber belajar lainnya) dalam rangka mencapai tujuan yang diharapkan.

Kesimpulannya, pembelajaran adalah usaha sadar dari guru untuk membuat siswa belajar, yaitu terjadinya perubahan tingkah laku pada diri siswa yang belajar, adanya perubahan itu maka, terdapat kemampuan baru yang berlaku dalam waktu relative lama dengan adanya usaha. Dengan demikian dapat diketahui bahwa kegiatan pembelajaran merupakan kegiatan yang melibatkan beberapa komponen.

\subsubsection{Komponen-komponen dalam pembelajaran yaitu:}

\subsubsection{Tujuan}

Tujuan pembelajaran merupakan komponen paling penting yang harus ditetapkan dalam proses pembelajaran yang mempunyai fungsi sebagai tolak ukur keberhasilan pembelajaran. Tujuan ini pada dasarnya merupakan rumusan tingkah laku dan kemampuan yang harus dicapai dan dimiliki peserta didik setelah menyelesaikan pengalaman dan kegiatan belajar dalam proses pembelajaran. Tujuan pembelajaran merupakan perangkat kegiatan belajar mengajar yang direncanakan untuk mencapai tujuan yang disebut tujuan instruksional. Menurut B. Suryo Subroto (2002 : 15) tujuan instruksional adalah rumusan secara 
terperinci tentang apa saja yang harus dikuasai oleh siswa sesudah mengakhiri kegiatan instruksional yang bersangkutan dengan keberhasilan.

\subsubsection{Materi}

Materi adalah bahan ajar yang ingin di sampaikan dalam pembelajaran, dalam penyampaian materi pembelajaran hendaknya guru perlu memperhatikan secara sistematis dengan mempertimbangkan urutan keluasan materi dan kedalaman materi, Ekosiwoyo (1996:49). Menurut Uzer Usman, dan Lilis S. (1993 : 39) analisis materi pelajaran merupakan penguraian dari pokok bahasan kedalam bagian-bagian atau mata pelajaran dengan penelaah serta menghubungkan antara bagian untuk memperoleh pengetahuan dan pemahaman secara keseluruhan. Bahan pelajaran pada hakekatnya adalah isi dari mata pelajaran atau bidang studi yang diberikan pada peserta didik sesuai dengan kurikulum yang digunakan.

\subsubsection{Metode}

Metode adalah suatu cara untuk melakukan tindakan Ramli (2008:8). Metode adalah suatu kerangka kerja untuk melakukan tindakan, atau suatu kerangka berfikir menyusun suatu gagasan, yang beraturan, terarah dan terkonteks, yang relevan dengan maksud dan tujuan, Sumaryanto (2007:9) Jadi metode adalah suatu kerangka kerja berupa proses, prinsip-prinsip dan prosedur untuk melakukan tindakan, atau suatu kerangka berfikir menyusun gagasan, yang beraturan, terarah dan terkonteks, yang relevan dengan maksud dan tujuan untuk mencari jawaban. 
Djramah (1997:48) menyatakan bahwa metode merupakan salah satu dari beberapa komponen pendidikan yang baku dalam system pembelajaran. Sedangkan menurut Hasibuan (1980:96) mendefinisikan metode sebagai alat yang merupakan bagian dari perangkat alat dan cara dalam pelaksanaan suatu strategi belajar mengajar.

Efektif tidaknya penggunaan metode pembelajaran untuk mencapai tujuan sangatlah bergantung pada kemampuan seorang guru dalam meningkatkan motovasi belajar siswa, dan penggunaan metode yang tidak tepat dapat menjadi penghambat paling besar dalam proses pembelajaran (Pasaribu \& Simanjutntak 1983:12). Metode dapat diartikan sebagai suatu cara atau teknik yang akan digunakan oleh pengajar dalam menyampaikan materi untuk mencapai tujuan pembelajaran (Daryanto dan Mulyo Raharjo, 2012:148)

\subsubsection{Media}

Media merupakan bahan pengajar dengan atau tanpa peralatan yang digunakan untuk menyajikan informasi kepada siswa. Fungsi media dalam pembelajaran yaitu: (1). Menangkap suatu objek atau peristiwa tertentu. Peristiwaperistiwa penting atau objek yang langka, dapat diabadikan dengan foto film atau direkam kemudian peristiwa itu dapat disampaikan dan digunakan manakala diperlukan. (2). Memanipulasi keadaan, peristiwa atau objek tertentu. Misalnya guru akan menjelaskan tentang candi Borobudur di dalam kelas maka guru dapat membuat miniature atau model candi tersebut dalam ukuran kecil. (3). Kesempatan belajar yang lebih merata. Dengan menggunakan berbagai video, audio, slide suara, dan sebagainya.Memungkinkan setiap orang dapat belajar 
dimana saja dan kapan saja. (4). Pengajaran lebih berdasarkan ilmu. Dengan menggunakan media proses belajar mengajar akan lebih terencana dengan baik sebab media dianggap sebagai bagian yang integral dari system belajar mengajar, oleh sebab itu sebelum pelaksanaannya guru dihadapkan kepada satu keharusan untuk mengidentifikasi dan karakteristik itu siswa sehubungan dengan menggunakan media.

\subsubsection{Evaluasi}

Evaluasi berasal dari kata evaluation. Fernandes (dalam Wardani, 2012: 5), mengatakan bahwa evaluasi merupakan proses pengajaran, pencarian dan pemberian informasi yang sangat bemanfaat bagi pengambil keputusan dalam menentukan alternatif keputusan.

Dalam proses pembelajaran evaluasi menempati kedudukan yang penting dan merupakan bagian utuh dari proses dan tahapan kegiatan pembelajaran. Dengan melakuan evaluasi, guru dapat mengukur tigkat keberhasilan proses pembelajaran yang dilakukannya, pada setiap kali pertemuan, setiap semester setiap tahun bahkan selama berada pada satuan pendidikan tertentu Aunrrohman, (2012: 203). Secara umum evaluasi bertujuan untuk melihat sejauh mana suatu program atau suatu kegiatan tertentu dapat mencapai tujuan yang telah ditentukan.

Evaluasi harus dilakukan oleh semua yang bersangkutan, bukan hanya guru, tapi juga siswa sendiri, evaluasi harus ditinjau secara keseluruhan. Berdasarkan hasil evaluasi, guru dapat mengetahui sampai mana dimana penguasaan bahan pelajaran atau kecakapan masing-masing siswa.Selain itu evaluasi juga dapat digunakan guru sebagai alat untuk memperbesar motivasi 
belajar siswa, sehingga dapat mencapai prestasi belajar yang lebih tinggi. (Riyana Cepy: 2011: komponen-komponen pembelajaran:11-53:www.file. UPI. Edu/directori.com). Evaluasi merupakan suatu proses untuk mengumpulkan informasi, mengadakan pertimbangan-pertimbangan mengenai informasi tadi, serta mengambil keputusan berdasarkan pertimbangan-pertimbangan yang telah dilakukan. (Asep Jihad \& Abdul Haris, 2012:149)

\subsection{Pembelajaran Seni Musik}

Musik merupakan ungkapan batin yang dinyatakan dengan irama nada yang melodis.Melodis seni musik adalah suara, karena itu pengamatan auditif (Bustomi, 1992).Pendidikan kesenian, sebagaimana yang dinyatakan Ki Hajar Dewantara, merupakan salah satu faktor penentu dalam membentuk kepribadian anak, karena pendidikan seni di sekolah dapat dijadikan sebagai dasar pendidikan dalam membentuk jiwa dan kepribadian.

Dalam rangka mencapai tujuan pendidikan nasional, pembelajaran seni musik sangat memberi kontribusi yang besar dalam pembentukan manusia Indonesia seutuhnya. Pembelajaran seni musik merupakan pembelajaran yang memberikan kemampuan mengekspresikan seni secara kreatif untuk pengembangan kepribadian siswa dan memberikan sikap-sikap atau emosonal yang seimbang. Seni musik membentuk disiplin, toleran, sosialisasi, sikap demokrasi yang meliputi kepekaan terhadap lingkungan Jamalus, (1998;91) dalam (Wicaksono, 2009). Menurut Jamalus (1988:3), Pembelajaran seni musik adalah pembelajaran tentang bunyi. 
Apapun yang dibahas dalam suatu pembelajaran musik haruslah bertitik tolak pada bunyi itu sendiri. Musik adalah suatu hasil karya seni bunyi dalam bentuk lagu atau komposisi musik, yaitu irama, melodi, harmoni, bentuk atau struktur lagu, dan ekspresi sebagai satu kesatuan, Jamalus (1988:1). Pembelajaran seni musik guru hendaknya tidak hanya menggunakan salah satu metode saja dalam mengajar.Agar pembelajaran tidak membosankan, guru harus dapat menggabungkan beberapa metode dalam pembelajaran seni musik,seperti metode ceramah, Tanya jawab, drill, demonstrasi, bermain peran, dan eksperimen. Adapun penggunaan metode pembelajaran musik tersebut menurut Jamalus dan Mahmud (1981: 37-38): Metode ceramah, Metode demonstrasi, Metode tanya jawab, Metode eksperimen.

Agar menarik dan mudah dimengerti siswa, dalam pembelajaran seni musik hendaknya guru juga menggunakan lagu model, yang dimaksud lagu model ialah lagu yang mengandung unsur-unsur musik yang akan diajarkan kepada siswa seperti irama, melodi dan bentuk komposisi,paduan nada, warna nada, dan unsur ekspresif Jamalus, (1981: 40). Penggunaan lagu model, diharapkan siswa akan lebih aktif dalam proses belajar mengajar. Sehingga materi yang diajarkanakan cepat diserap oleh siswa. Dalam penelitian lagu model pun guru diharapkan memilih lagu atau musik-musik yang berkualitas, lagu yang dipilih dapat berupa lagu-lagu pop yang sedang popular, lagu kebangsaan, dan dapat juga dengan lagu daerah yang sudah dikenal siswa atau pun lagu baru yang mudah, yang mengandung unsur-unsur musik untuk dijadikan bahan pembelajaran, karena 
tugas guru ialah membantu siswa siswinya untuk meningkatkan rasa keindahan musiknya dengan mendengarkan bermacam-macam jenis musik yang berkualitas.

Guru juga harus memberikan kepada siswa tentang unsur-unsur musik yang harus diamati dengan musik yang akan didengarkan. Jika tidak ada arahan atau bimbingan, siswa akan kebingungan mendengarkan musik, dan tidak tau apa yang harus diperhatikannya. Adapun unsur-unsur pokok meliputi: irama, melodi, harmoni dan bentuk atau struktur lagu. Unsur-unsur ekspresi meliputi: tempo, dinamik dan warna nada, Jamalus (1988:7).

\subsubsection{Melodi}

Melodi adalah rangkaian dari beberapa nada atau sejumlah nada yang berbunyi atau dibunyikan secara berurutan (Soeharto. 1992:1)

\subsubsection{Irama}

Irama (ritme) adalah urutan rangkaian gerak yang menjadi unsur dalam sebuah musik (Jamalus, 1988:7).

\subsubsection{Harmoni}

Harmoni atau paduan nada ialah bunyi gabungan dua atau lebih, yang berbeda tinggi rendahnya dan dibunyikan secara serentak. Dasar dari paduan nada tersebut ialah trinada (Jamalus, 1988:30)

Pencapaian tujuan dengan baik maka pembelajaran seni musik seharusnya menggunakan alat penunjang. Alat penunjang tersebut berupa alat musik, namun tidak harus alat musik yang modern, yang penting sesuai materi yang diajarakan dan mudah didapat, dan sesuaikan dengan situasi kondisi yang ada. Dengan alat penunjang siswa akan lebih tertarik, aktif, dan cepat menguasai materi yang di 
ajarkan. Misal alat musik yang masih dijangkau oleh para siswa yaitu pianika, recorder/suling dan gitar, dengan alat-alat musik yang sederhana tersebut para siswapun dapat mempelajari sendiri.

Dari uraian tersebut dapat dijelaskan bahwa pembelajaran seni musik adalah proses kegiatan belajar mengajar pengalaman musik, yaitu kegiatan mendengarkan musik, bernyanyi, bermain musik, bererak mengikuti musik, membaca musik, dan membangun kreatifitas siswa dalam bermusik. Kegiatan ini juga bertujuan untuk menjadikan siswa lebih kreatif dan aktif dan siswa dapat dapat meningkat sendiri pengetahuan dan kemampuan dalam bidang musik. Adapun tujuan lain ialah untuk mengembangkan fungsi jiwa, perkembangan pribadi dengan memperhatikan lingkungan sosial budaya siswa di sekolah dan dapat dilakukan kehidupan sehari-hari sesuai dengan kemampuan berpikir serta perkembangan mental dan fisik siwa.

\subsection{Kerangka berfikir}

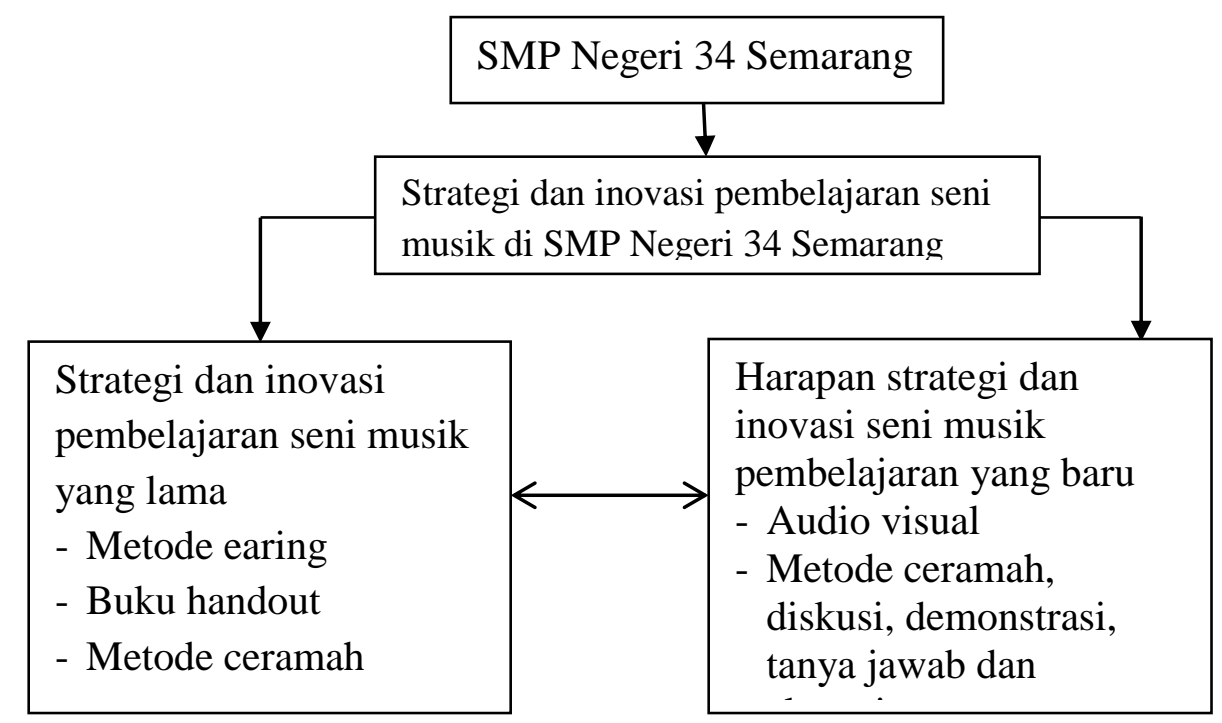

Bagan 1. Kerangka berfikir untuk melakukan penelitian di SMP Negeri 34 Semarang

(Sumber : Ahadiah Februari 2016) 


\section{BAB III \\ METODE PENELITIAN}

\subsection{Pendekatan Penelitian}

Pendekatan yang digunakan dalam penelitian ini adalah pendekatan kualitatif yang memiliki sifat deskriptif. Pendekatan ini dipilih karena permasalahan yang dibahas dalam penelitian ini bertujuan untuk menggambarkan atau menguraikan tentang hal-hal yang berhubungan dengan strategi dan inovasi pembelajaran seni musik di SMP N 34 Semarang. Perolehan data dengan pendekatan kualitatif merupakan sumber dari deskripsi yang luas dan memuat penjelasan tentang proses yang terjadi dalam lingkungan setempat, dengan data kualitatif kita dapat mengikuti dan memahami alur peristiwa secara kronologis, menilai sebab akibat dalam lingkup pikiran orang-orang setempat dan dapat memperoleh penjelasan yang banyak dan sangat bermanfaat (terjemah Miles dan Huberman dalam Rohedi, 1992:1-2)

Penelitian ini tidak menggunakan angka-angka, melainkan memberi penjelasan dan pemahaman secara menyeluruh dan sistematis terhadap kaitan hubungan permasalahan yang dikaji.

\subsection{Lokasi dan Sasaran Penelitian}

\subsubsection{Lokasi Penelitian}

Lokasi penelitian merupakan tempat dilakukan kegiatan penelitian. Sehubungan dengan permasalahan maka, penelitian ini mengambil lokasi di SMP N 34 Semarang. Penelitian ini merupakan penelitian di bidang pendidikan tentang 
dilakukannya strategi dan inovasi pembelajaran seni musik di SMP N 34 Semarang.

\subsubsection{Sasaran Penelitian}

Adanya sasaran penelitian ini adalah untuk mengetahu proses dilakukannya strategi dan inovasi pembelajaran, manfaat bagi guru itu sendiri dan respon para murid di SMP N 34 Semarang.

\subsection{Teknik Pengumpulan Data}

Untuk menjawab masalah penelitian, dibutuhkan suatu data. Data diperoleh melalui kegiatan pengumpulan data. Pengumpulan data dalam suatu penelitian dimaksudkan untuk memperoleh keterangan, kenyataan atau informasi yang bener dan dapat dipercaya. Data yang dimaksud adalah data yang ada hubungannya dengan tujuan penelitian.

Dalam penelitian ini teknik yang digunakan adalah:

\subsubsection{Teknik Observasi}

Observasi adalah pengamatan langsung para pembuat keputusan berikut lingkungan fisiknya dan pengamatan langsung suatu kegiatan yang sedang berjalan. Di dalam survey, di dalam eksperimen, maupun di dalam metode-metode penyelidikan yang lain, banyak dilakukan teknik observasi untuk mengumpulkan data. Dengan tujuan tertentu, misalnya dalam mengumpulkan bahan mengenai proses perubahan sesuatu hal yang nampak. Meliputi kegiatan pemusatan perhatian terhadap obyek penelitian dengan menggunakan seluruh indera atau pengamatan langsung. Kegiatan observasi yang dilakukan dalam penelitian ini adalah observasi yang berjenis non partisipan meliputi: 1) Kegiatan belajar 
mengajar dikelas yang menyangkut kegiatan murid dan guru. 2) Proses pelaksanaan strategi dan inovasi pembelajaran seni musik. 3) Situasi belajar mengajar. 4) Cara yang dilakukan pengajar untuk menyampaikan materi. 5) Ketertarikan siswa terhadap materi dan sejauh apa mereka mampu menyerap materi.

\subsubsection{Teknik Wawancara}

Teknik wawancara dalam suatu penelitian merupakan teknik pengumpulan data yang penting, sebab dengan wawancara akan didapatkan data secara langsung dari para informan, sehingga dapat mengetahui dan mendapatkan data yang dibutuhkan dari orang-orang yang terlibat dalam proses wawancara. Berdasarkan pengertian tersebut, wawancara yang digunakan dalam penelitian ini adalah interview bebas terpimpin yaitu pewawancara membawa pedoman yang merupakan garis besar tentang hal yang akan di teliti. Wawancara tersebut di tujukan kepada guru mata pelajaran seni musik mendapat informasi tentang bagaimana keadaan kelas saat waktu jam pelajaran seni musik, pengalaman selama mengajar seni budaya khususnya seni musik, cara menghadapi siswa saat mengajar, materi yang diajarkan, metode yang digunakan sebelumnya, kendala saat mengajar, respon para siswa dengan pelajaran seni musik. Wawancara tersebut ditujukan kepada Kepala sekolah, Guru pengampu dan siswa-siswi kelas $8 \mathrm{c}$.

Moleong (1994:135) wawancara adalah percakapan dengan maksud tertentu. Percakapan itu dilakukan oleh dua pihak yaitu pewawancara (interviewer) yang mengajukan pertanyaan dan yang diwawancarai (interviewee) 
yang memberikan jawaban atas pertanyaan itu. Maksud dari pengertian tersebut adalah bahwa, seorang pewawancara menyampaikan pertanyaan kepada orang lain atau informan, kemudian jawaban informan digali dan di catat sebagai bukti data hasil wawancara untuk mendapatkan data tentang peneliti ini, penelitian menggunakan teknik wawancara terbuka, artinya wawancara dilakukan tidak terstruktur dan bersifat informal, hal ini dilakukan dengan tujuan untuk menciptakan kondisi yang wajar, alamiah, dan komunikasi yang akrab antara pewancara dan yang diwawancarai. Bahkan wawancara dilakukan secara spontan tanpa ada perjanjian resmi terlebih dahulu, serta tidak terkait terhadap lokasi atau tempat terjadinya wawancara sedangkan, bentuk pertanyaan diusahakan lebih banyak memberikan kesempatan kepada informan untuk mengeluarkan pendapat atau keterangan.

\subsubsection{Teknik Dokumentasi}

Dokumentasi dalam suatu penelitian merupakan suatu keharusan berkenaan dengan penelitian dengan pendekatan deskriptif kualitatif, karena dengan menggunakan teknik dokumentasi, hasil dokumentasi akan dapat mewakili penjelasan, sehingga memberikan data lebih jelas dan lebih komplek. Dokumen yang dimaksud dapat berupa foto, buku atau dokumen lain. Arikunto (1991:135) berpendapat teknik dokumentasi adalah mencari data mengenai halhal atau variable yang berasal dari catatan buku, surat kabar, majalah, prasasti, notulen, agenda foto dan lain sebagainya dengan demikian, teknik dokumentasi dilakukan bertujuan untuk mencari, dan melengkapi data yang belum diperoleh dari hasil observasi dan wawancara. Dokumen yang disertakan dalam penelitian 
ini antara lain: (1) perangkat pembelajaran yang dibuat oleh guru seni musik seperti satuan pelajaran dan rencana pembelajaran. (2) foto lokasi penelitian, foto saat pembelajaran di kelas secara teori dan praktik, dan foto hasil pembelajaran seni musik.

\subsection{Teknik Pemeriksaan Keabsahan Data}

Data atau dokumen yang diperoleh dalam penelitian kualitatif itu perlu diperiksa keabsahannya. Teknik yang dipakai dalam penelitian ini memakai derajat kepercayaan, yaitu pelaksanaan dengan pembuktian oleh peneliti pada kenyataan ganda yang sedang diteliti sehingga tigkat kepercayaan penemuan dalam kriterium ini dapat dipakai. Dalam teknik pengumpulan data, triangulasi diartikan sebagai teknik pengumpulan data yang bersifat menggabungkan dari berbagai teknik pengumpulan data dan sumber yang telah ada (Sugiyono, 2010: 330). Menurut Susan Stainback (dalam Sugiyono, 2010: 330) mengatakan tujuan dari trianggulasi bukan untuk mencari kebenaran tentang bebrapa fenomena, tetapi lebih pada peningkatan pemahaman peneliti terhadap apa yang telah ditemukan.

Ada dua jenis triangulasi yang pertama triangulasi teknik, yaitu penelitian mengunakan tenik pengumpulan data yang berbeda-beda untuk mendapatkan data dari sumber yang sama. Yang kedua triangulasi sumber yaitu mendapatkan data dari sumber yang berbeda-beda dengan tenik yang sama. Dalam penelitian ini digunakan triangulasi sumber penulis melakukan perbandingan dan pengecekan baik derajat kepercayan suatu informasi yang diperoleh pada waktu dan alat yang berbeda. Artinya mengecek kebenaran data tertentu dan membandingkan dengan 
data yang diperoleh dari sumber lain pada berbagai fase penelitian lapangan pada waktu yang berlainan dengan menggunakan metode yang berlainan. Teknik trangulasi yang digunakan adalah menggunakan sumber data informasi dari kepala sekolah, guru, siswa saat dilaksanakannya kegiatan belajar mengajar.

\subsection{Teknik Analisis Data}

Analisis Data Kualitatif (Bodgan \& Biklen, 1982) adalah upaya yang dilakukan dengan jalan bekerja dengan data, mengorganisasikan data, memilahmilahnya menjadi satuan yang dapat dikelola, mensintesiskannya, mencari dan menemukan pola, menemukan apa yang penting dan apa yang dipelajari, dan memutuskan apa yang dapat diceritakan kepada orang lain.

Di pihak lain, Analisis Data Kualitatif (Seiddel, 1998), prosesnya berjalan seperti berikut yaitu : 1) Mencatat yang menghasilkan catatan lapangan, dengan hal itu diberikan. 2) kode agar sumber datanya tetap dapat ditelusuri. 3) Mengumpulkan, memilah-milah, mengklasifikasikan, mensintesiskan, membuat ikhtisar, dan membuat indeksnya. 4) Berpikir, dengan jelas membuat agar kategori data itu mempunyai makna, mencari dan menemukan pola dan hubungan-hubungan, dan membuat temuan-temuan umum.

Analisis data, menurut Patton (1980:268), adalah proses mengatur urutan data, mengorganisasikannya kedalam suatu pola, kategori, dan satuan uraian dasar. Dengan demikian definisi tersebut bias disimpulkan menjadi: Analisi data adalah proses mengorganisasikan dan mengurutkan data kedalam pola, kategori, dan satuan uraian dasar sehingga dapat ditemukan tema dan dapat dirumuskan hipotesis kerja seperti yang disarankan oleh data. Analisis data terbagi menjadi 
tiga, yaitu:1). Reduksi data merupakan menajamkan, menggolongkan, mengarahkan, membuang yang tidak perlu dan mengorganisasikan data sedemikian rupa sehingga dapat ditarik simpulan dan verifikasinya.2). Penyajian data berarti menemukan makna dari data, disusun secara sistematis. 3). Penarikan kesimpulan merupakan upaya mencari makna terhadap data dengan mencari pola, tema, hubungan, persamaan dan hal-hal yang sering timbul.

Berikut adalah skema analisis data kualitatif menurut Miles dan Huberman (dalam Sugiono, 2010: 338).

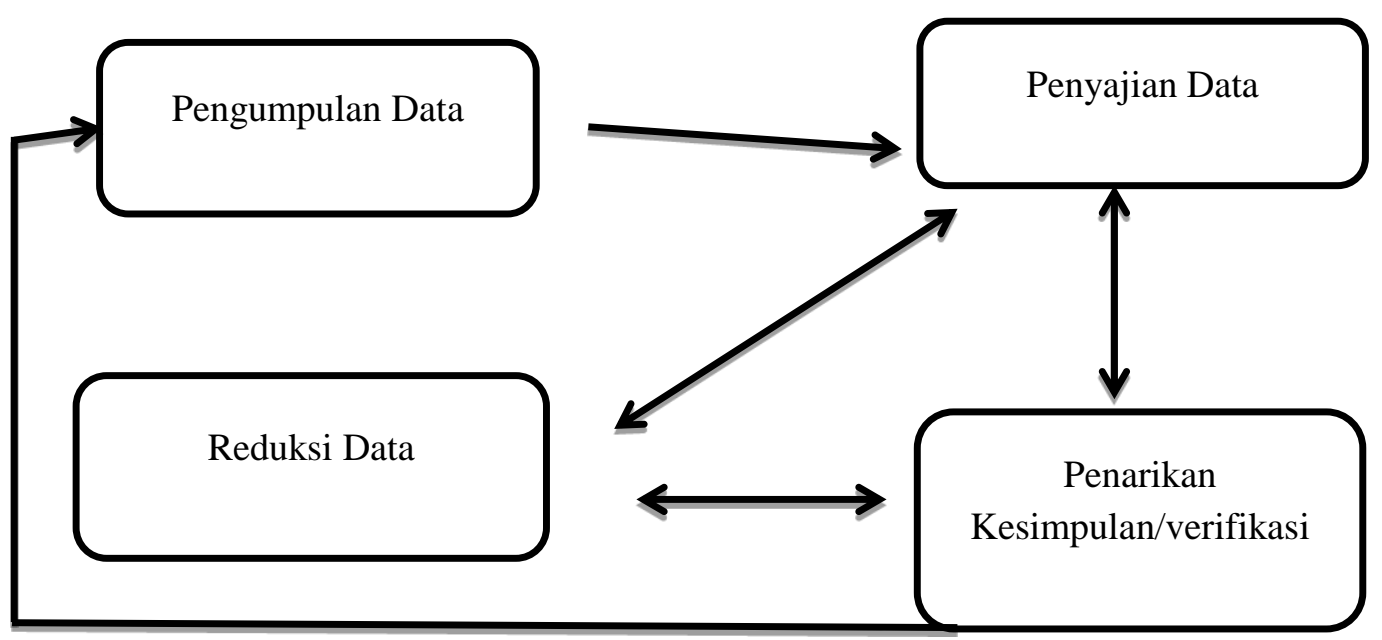

Sumber : Analisis Data Kualitatif Miles dan Huberman (dalam Sugiyono, 2010 : 338). 


\section{BAB IV}

\section{HASIL PENELITIAN DAN PEMBAHASAN}

\subsection{Hasil Penelitian}

Pemaparan hasil penelitian dan pembahasan pada bab ini terdiri atas tiga sub bab yaitu (1) Gambaran umum dan sejarah singkat SMP N 34 Semarang, (2) Strategi pembelajaran seni musik di SMP N 34 Semarang, (3) Inovasi pembelajaran seni musik di SMP N 34 Semarang.

\subsubsection{Gambaran Umum dan Sejarah Singkat SMP N 34 Semarang}

SMP N 34 Semarang adalah salah satu SMP Negeri di Semarang, tepatnya berada di J1 Tlogomulyo Kecamatan Pedurungan kota Semarang, Jawa Tengah. Letak sekolah ini berada di tengah-tengah desa dan dikelilingi oleh kebun pisang. Sebelah kiri SMP N 34 Semarang adalah kantor kelurahan Tlogomulyo dan sebelah kanannya adalah SD Pedurungan Tengah 01 dan menghadap ke utara serta sekeliling sekolah merupakan daerah pemukiman perumahan BPD.

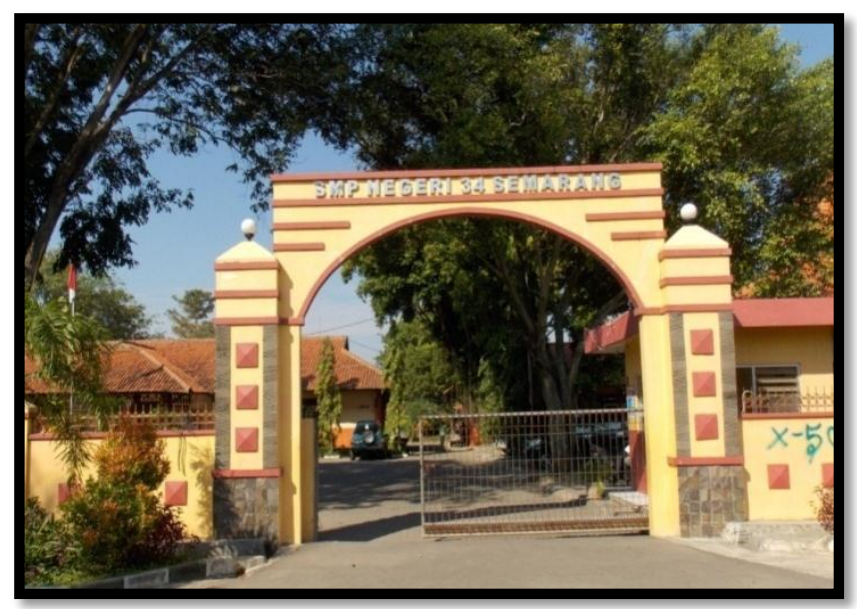

Foto. 1 Gerbang utama SMP N 34 Semarang

(Sumber: Ahadiah Februari 2016) 
Masyarakat sekitar yang bermukim di lingkungan SMP Negeri 34 Semarang merupakan pekerja karir sebagai karyawan swasta dan PNS. SMP Negeri 34 Semarang merupakan sekolah yang terletak di tengah-tengah perumahan dan jauh dari jalan raya sehingga jumlah kendaraan yang lewat permenitnya sangat sedikit sehingga tingkat kebisingan sangat minim yang membuat proses KBM menjadi nyaman. Lingkungan sekolah SMP N 34 Semarang ketika musim hujan datang sering terkena banjir dari dulu dan bahkan sekarangpun terkadang banjir masih menjadi langganan ketika hujan turun begitu deras.

SMP N 34 Semarang berdiri sejak tahun 1991/1992 tepatnya 18 Juli 1991. Selama sekolah dibangun siswa menginduk di SMP Negeri 15 Semarang, dan setelah tahun 1993 siswa sudah menempati gedung sekolah sendiri di SMP Negeri 34 Semarang. Sepanjang karirnya SMP N 34 Semarang mengalami banyak kemajuan dan perubahan demi perubahan sehingga kini menjadi sekolah standar nasional.

SMP N 34 Semarang juga memiliki satu buah mushola dengan luas 120 $\mathrm{m}^{2}$, digunakan sebagai tempat ibadah juga sebagai sarana belajar baik kurikuler maupun ekstrakurikuler seperti rebana, uji praktek agama islam, sholat berjamaah dan kegiaatan baca tulis Al-qur'an. SMP N 34 Semarang memiliki 7 kantin dengan luas masing-masing $8 \mathrm{~m}^{2}$ yang berfungsi sebagai tempat untuk melayani para guru dan siswa yang membutuhkan makanan dan minuman. 


\subsubsection{Visi dan Misi Sekolah}

\subsubsection{Visi SMP N 34 Semarang}

Visi yang diterapkan oleh SMP N 34 Semarang adalah :

"Unggul dalam prestasi dengan berlandaskan iman dan takwa"

\subsubsection{Misi SMP N 34 Semarang}

Misi yang ingin dicapai SMP N 34 Semarang adalah sebagai berikut :

1) melaksanakan pembelajaran dan bimbingan secara efektif untuk mengoptimalkan potensi yang dimiliki siswa. 2) menumbuh kembangkan penghayatan dan pengamalan terhadap agama yang dianut untuk membentuk budi pekerti yang baik. 3) menciptakan suasana yang kondusif untuk keefektifan seluruh kegiatan di lingkungan sekolah. 4) mengembangkan budaya kompetitif bagi siswa dalam upaya peningkatan prestasi di segala bidang. 5) mengutamakan kerja sama (teamwork) dalam menyelesaikan tugas kependidikan dan keguruan. 6) melestarikan dan mengembangkan olah raga, seni dan budaya

\subsubsection{Keadaan Fisik Sekolah}

Kondisi fisik sekolah merupakan salah satu faktor yang sangat mempengaruhi siswa-siswi dalam kegiatan belajar mengajar. Jika kondisi fisik tidak mendukung dalam kegiatan belajar siswa-siswi akan tidak nyaman untuk melakukan kegiatan belajar. SMP N 34 Semarang berada di Jalan Tlogomulyo, Kecamatan Pedurungan Semarang dengan luas $15.925 \mathrm{~m}^{2}$ dan luas bangunan sekolah $3.416 \mathrm{~m}^{2}$. Ruang kelas terdiri dari 24 ruang yang telah ditentukan penggunaanya, yaitu 8 ruang untuk kelas VII, 8 ruang untuk kelas VIII dan 8 
ruang untuk kelas IX. Selain ruang kelas yang berjumlah 24 ruang kelas, SMP N 34 Semarang juga memiliki bangunan lain yaitu :

\section{1) Ruang Kepala Sekolah}

Ruang kepala sekolah SMP N 34 Semarang memiliki luas $14 \mathrm{~m}^{2}$.Ruang ini merupakan tempat kerja bagi kepala sekolah sekaligus untuk menerima tamu yang berkepentingan langsung dengan kepala sekolah.

2) Ruang Guru

Jumlah guru di SMP N 34 Semarang adalah 42 guru dan kesemuanya telah mendapat meja dan kursi pribadi di ruang guru.Meja dan kursi pribadi tersebut difasilitasi agar guru-guru dapat melakukan tugas-tugas tata tulis sekolah, melakukan koreksi dan penilaian serta dapat menyimpan peralatan mengajarnya.

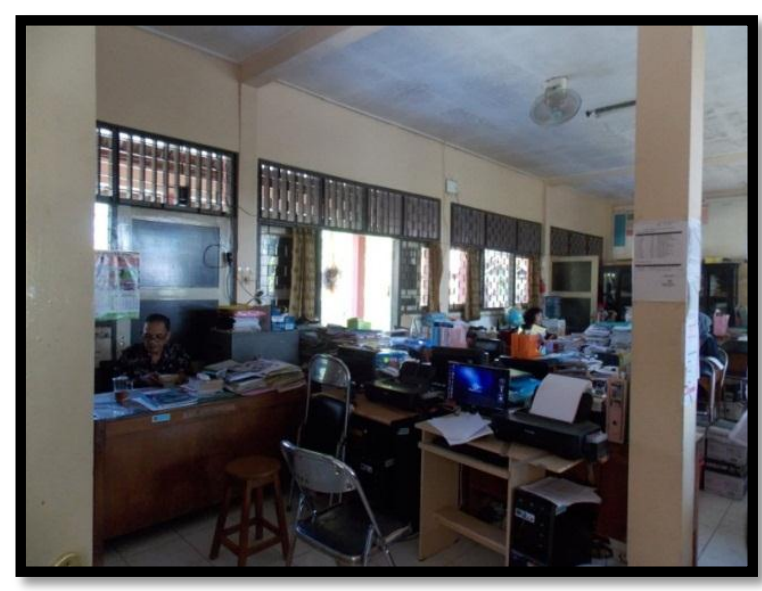

\section{Foto 2 Ruang Guru SMP N 34 Semarang}

( Sumber: Ahadiah Februari 2016)

3) Ruang Tata Usaha

Ruang tata usaha SMP N 34 Semarang memiliki luas $45 \mathrm{~m}^{2}$. Bagian tata usaha memiliki karyawan berjumlah 8 orang. Masing-masing karyawan memiliki tugas yang berhubungan dengan administrasi sekolah serta penyimpanan surat arsip sekolah. 


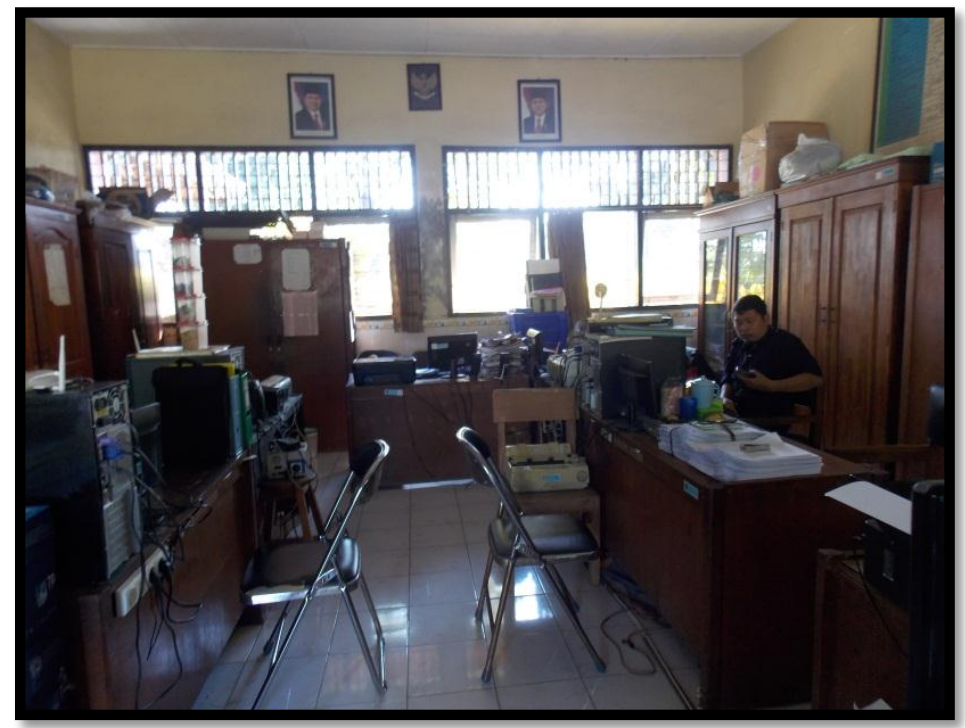

Foto 3 Ruang Tata Usaha SMP N 34 Semarang

( Sumber: Ahadiah Februari 2016 )

4) Ruang UKS

Ruang UKS SMP N 34 Semarang memiliki luas $15 \mathrm{~m}^{2}$.UKS digunakan sebagai tempat istirahat sementara bagi siswa yang sedang sakit. Selain itu juga sebagai tempat untuk menyimpan obat-obatan. Di UKS jadwal juga dilakukan oleh siswa.

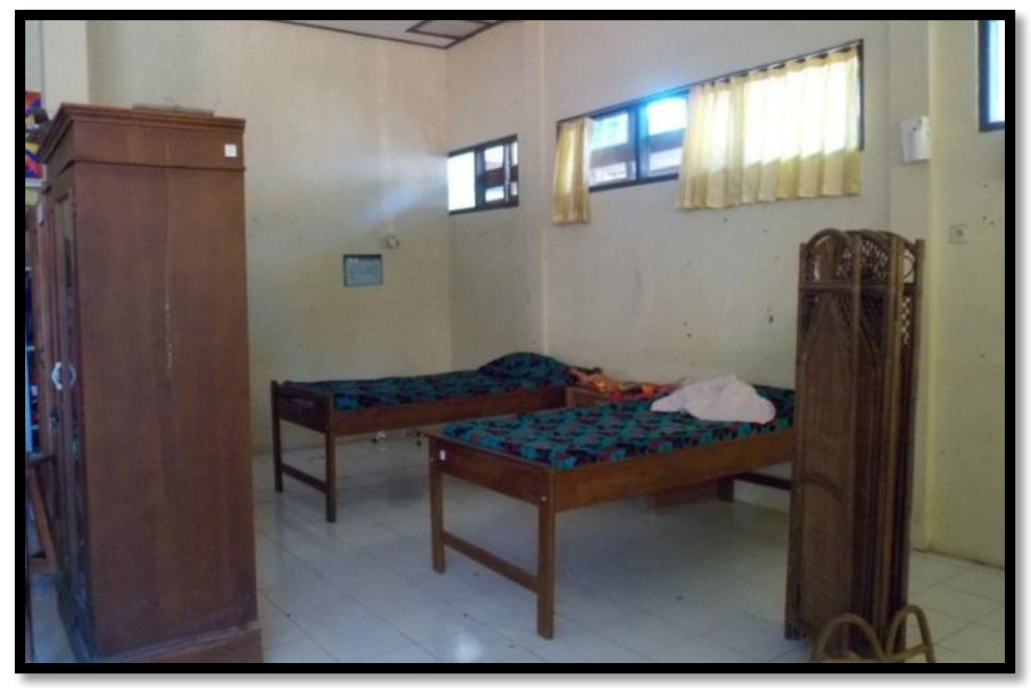

Foto 4 Ruang UKS SMP N 34 Semarang

( Sumber: Ahadiah Februari 2016 ) 
Daftar ruang dan bangunan di SMP N 34 Semarang :

\begin{tabular}{|c|l|c|}
\hline No & \multicolumn{1}{|c|}{ Nama Bangunan } & Jumlah Bangunan \\
\hline 1 & Ruang Kelas & 24 Bangunan \\
2 & Ruang Guru & 2 Bangunan \\
3 & Ruang Kepala Sekolah & 1 Bangunan \\
4 & Ruang Perpustakaan & 1 Bangunan \\
5 & Ruang TU & 1 Bangunan \\
6 & Ruang UKS & 1 Bangunan \\
7 & Ruang BK & 1 Bangunan \\
8 & Mushola & 1 Bangunan \\
9 & Toilet Guru & 2 Bangunan \\
10 & Toilet Siswa & 4 Bangunan \\
11 & Laboratorium Bahasa & 1 Bangunan \\
12 & Laboratorium IPA & 2 Bangunan \\
13 & Gudang & 1 Bangunan \\
14 & Ruang Serba Guna & 1 Bangunan \\
\hline
\end{tabular}

(Tabel 1, Jumlah Bangunan SMP N 34 Semarang)

(Sumber : Dokumentasi SMP N 34 Semarang, 2016)

\subsubsection{Tenaga Pengajar, Tenaga Pendukung, dan Data Siswa Kelas 8C}

Jumlah guru yang mengajar di SMP N 34 Semarang ada 39 dan tenaga pendukung seperti staf TU staf kebersihan dan penjaga sekolah secara keseluruhan ada 15. Berikut ini merupakan tabel jumlah tenaga pengajar, tenaga pendukung dan siswa.

Tenaga pengajar dan tenaga pendukung SMP N 34 Semarang

\begin{tabular}{|c|l|c|}
\hline No & \multicolumn{1}{|c|}{ Tenaga Kependidikan } & Jumlah \\
\hline 1. & Seni Budaya & 2 \\
\hline 2. & Matematika & 4 \\
\hline 3. & Agama Islam & 2 \\
\hline 4. & Penjaskes & 1 \\
\hline 5. & IPA & 5 \\
\hline 6. & IPS & 4 \\
\hline 7. & TIK \& Prakarya & 2 \\
\hline 8. & Bahasa Jawa & 3 \\
\hline 9. & Bahasa Indonesia & 5 \\
\hline 10. & Bahasa Inggris & 4 \\
\hline 11. & PPKN & 2 \\
\hline 12. & Agama Kristen & 1 \\
\hline
\end{tabular}




\begin{tabular}{|c|l|c|}
\hline 13. & BK & 4 \\
\hline 14. & Staf TU & 8 \\
\hline 15. & Tenaga Kebersihan & 5 \\
\hline 16. & Tenaga Keamanan & 2 \\
\hline
\end{tabular}

( Tabel 2, Tenaga pendidik dan tenaga pendukung )

( Sumber : Dokumentasi SMP N 34 Semarang 2016)

Jumlah Siswa 8C di SMP N 34 Semarang ada 29 yang terdiri dari 15 lakilaki dan 16 perempuan. Berikut tabel nama siswa yang berada di kelas 8C.

\begin{tabular}{|c|c|c|c|}
\hline \multirow{2}{*}{ NO } & \multirow{2}{*}{ NAMA SISWA } & \multicolumn{2}{|c|}{ JENIS KELAMIN } \\
\hline & & $\mathbf{L}$ & $\mathbf{P}$ \\
\hline 1. & ADHISTY ZAHRA SAPUTRI & $\mathrm{L}$ & \\
\hline 2. & ARLIA RAHMA HARIANTO & & $\mathrm{P}$ \\
\hline 3. & ARUM WULAN SAPUTRI & & $\mathrm{P}$ \\
\hline 4. & CALVIN FAISAL NUR RIZKI & $\mathrm{L}$ & \\
\hline 5. & CINTANIA SALSABELLA & & $\mathrm{P}$ \\
\hline 6. & DENY CAHYO WIBISONO & $\mathrm{L}$ & \\
\hline 7. & DIVA MEDINA HAPSARI M & & $\mathrm{P}$ \\
\hline 8. & IKKE RATNA SARI & & $\mathrm{P}$ \\
\hline 9. & JANUAR USSAC FAKHRI & $\mathrm{L}$ & \\
\hline 10. & JESSENIA MAYSUN & & $\mathrm{P}$ \\
\hline 11. & LIA LESTARI & & $\mathrm{P}$ \\
\hline 12. & M. DAFFA NAIL NASHIF & $\mathrm{L}$ & \\
\hline 13. & MANDA FATMASARI & & $\mathrm{P}$ \\
\hline 14. & MENTARI PUTRI ATMALIA & & $\mathrm{P}$ \\
\hline 15. & MUCHAMAD HASAN BASRI & $\mathrm{L}$ & \\
\hline 16. & MUHAMAD FARHADUL ASAD & $\mathrm{L}$ & \\
\hline 17. & MUHAMAD KRISNA A & $\mathrm{L}$ & \\
\hline 18. & NOVI MUTIASARI & & $\mathrm{P}$ \\
\hline 19. & NUGROHO PRASETYO & $\mathrm{L}$ & \\
\hline 20. & NUR ADIB AFIUDIN HIDAYAT & $\mathrm{L}$ & \\
\hline 21. & PUDI AJI CAKRA ATMAJA & & $\mathrm{P}$ \\
\hline 22. & PUTRI RAHMAWATI & & $\mathrm{P}$ \\
\hline 23. & ROYHAN ALMAS ZULFIKAR & & $\mathrm{P}$ \\
\hline 24. & SALSABIIL MEIRANI PRIMASTI & & $\mathrm{P}$ \\
\hline 25. & SHERLY OLIVIANI PUTRI & & $\mathrm{P}$ \\
\hline 26. & SUPRIYANTO & $\mathrm{L}$ & \\
\hline 27. & WAHYU DWI UTOMO & $\mathrm{L}$ & \\
\hline 28. & MUHAMMAD MALIK FAHAD & $\mathrm{L}$ & \\
\hline 29. & BELA ANANDA & & $\mathrm{P}$ \\
\hline
\end{tabular}

( Tabel 3, jumlah dan daftar nama siswa kelas 8C)

( Sumber : Dokumentasi SMP N 34 Semarang 2016 ) 


\subsubsection{Sarana dan Prasarana Sekolah}

Fasilitas yang tersedia di SMP N 34 Semarang cukup memadai. Sekolah ini mempunyai 24 ruang kelas. Setiap kelas terbagi menjadi 8 kelas, dan kebetulan gedung SMP N 34 Semarang tidak bertingkat jadi semua ruangan berada di lantai 1. Di setiap ruang kelas tersedia 1 white board, 1 meja dan kursi guru, 4 kipas angin, 1 LCD, 30 meja dan kursi siswa. Disediakan pula papan absensi siswa serta terdapat lambang negara Republik Indonesia, gambar presiden dan wakil presiden Indonesia. Selain itu disediakan pula papan informasi yang dipergunakan untuk kepentingan kelas dan sekolah sebagai petunjuk jika ada informasi yang ada di dalam kelas maupun di sekolah. Saat ini sekolah sudah dilengkapi dengan wifi yang mencakup ke seluruh lingkungan sekolah.

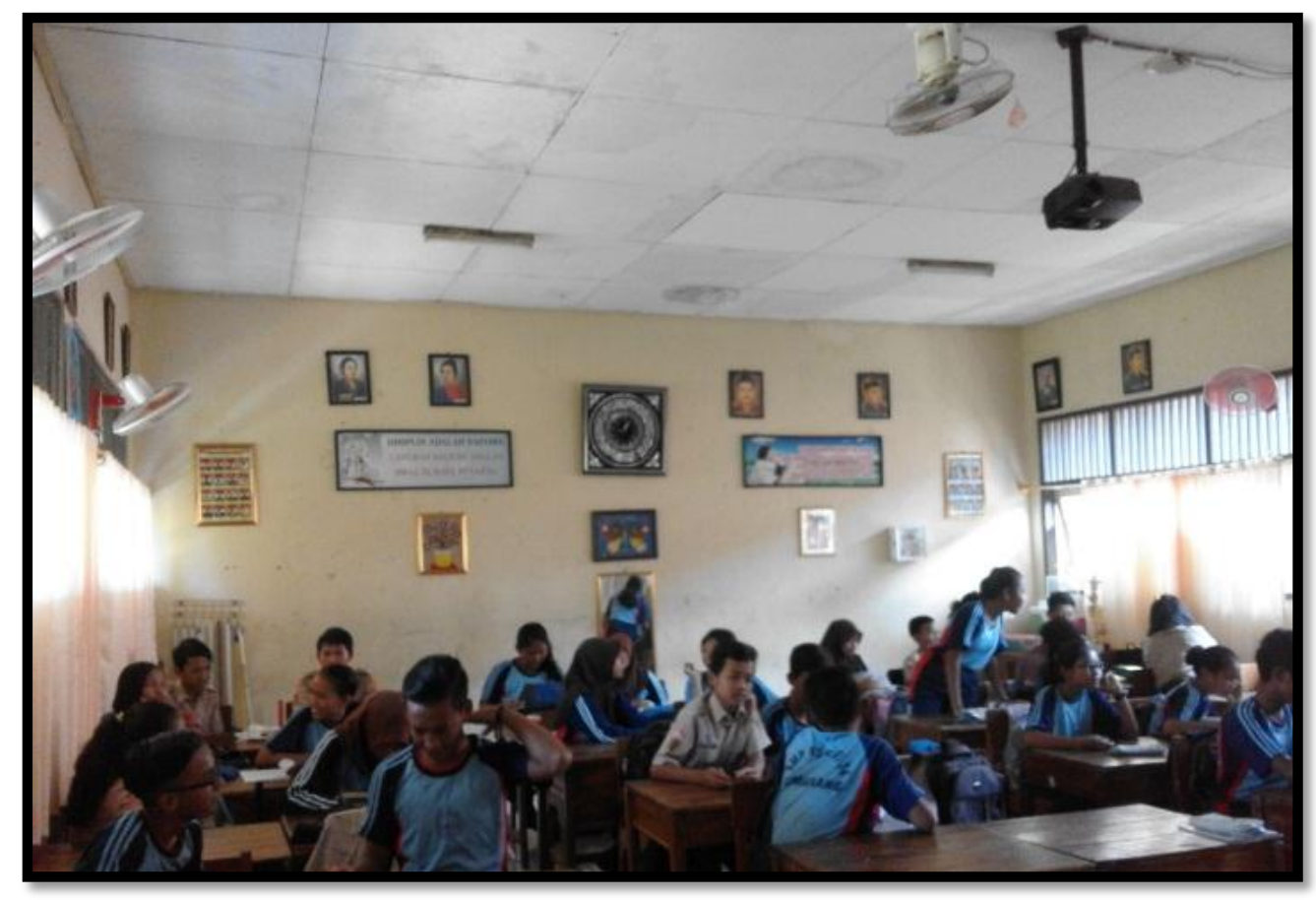

Foto 5, Keadaan ruang kelas 8C dan sarana prasarananya

( Sumber: Ahadiah Februari 2016 ) 


\subsection{Strategi Pembelajaran Seni Musik di SMP Negeri 34 Semarang}

Strategi pembelajaran dalam penelitian ini berkait dengan usaha menjawab masalah peneliti yang diangkat mengenai strategi pembelajaran di SMP Negeri 34 Semarang. Konsep strategi pembelajaran yang diterapkan ialah menganalisis masalah ini secara pokok menggunakan konsep strategi pembelajaran yang dikemukakan oleh (Khanifatul, 2014:15 dan Hamdani, 2011:24).

Khanifatul mengatakan strategi pembelajaran berkaitan dengan perencanaan pembelajaran untuk mencapai sebuah tujuan. Sedangkan Hamdani melihat strategi pembelajaran berkaitan dengan pengelolaan kegiatan, cara mengorganisasikan materi pelajaran, peralatan dan bahan serta waktu yang digunakan dalam proses pembelajaran. Apa yang dikemukakan oleh Khanifatul dan Hamdani nantinya yang akan digunakan oleh peneliti untuk melihat fenomena lapangan.

\subsubsection{Pengelolaan Kegiatan}

Pengelolaan kegiatan oleh guru telah direncanakan jauh sebelum kegiatan pembelajaran dilaksanakan. Apa yang dilihat di lapangan, praktek pengelolaan kegiatan oleh guru dalam proses belajar mengajar berhubungan dengan penyampaian materi, peralatan atau media yang digunakan dalam kegiatan pembelajaran, bahan serta waktu yang diterapkan dalam proses pembelajaran.

\subsubsection{Penyampaian Materi}

Dalam penelitian ini peneliti mengambil semple kelas 8C untuk dijadikan objek penelitian untuk memperoleh data yang relevan dari keadaan yang sebenarnaya di lapangan. Penyampaian informasi atau penyampaian materi 
dilakukan dengan menggunakan beberapa metode pembelajaran, yaitu metode ceramah, metode demonstrasi dan metode latihan.

Metode ceramah dapat diartikan sebagai cara menyajikan pelajaran melalui penuturan secara lisan atau penjelasan langsung kepada sekelompok siswa. Metode ini dapat menyajikan materi pelajaran yang lebih luas. Artinya, materi yang banyak dapat dirangkum atau dijelaskan pokok-pokoknya oleh guru dalam waktu yang singkat. Melalui metode ceramah guru seni musik di SMP Negeri 34 Semarang terlebih dahulu mempersiapkan pokok-pokok materi yang akan disampaikan atau diceramahkan sesuai dengan tujuan pembelajaran yang harus dicapai.

Setelah itu materi yang sudah dipersiapkan tersebut disampaikan pada saat pembelajaran berlangsung. Namun demikian, metode ceramah mempunyai kelemahan yaitu menimbulkan rasa bosan/jenuh kepada siswa, oleh karena itu guru memberikan selingan seperti candaan pada saat pembelajaran. Usaha tersebut dilakukan guru supaya dapat menciptakan suasana kelas/pembelajaran seni musik menjadi nyaman, peserta juga merasakan santai dan dapat lebih mudah menerima pelajaran yang disampaikan oleh guru.

Metode demonstrasi yaitu metode dengan memperagakan, memperaktekkan/ mencontohkan materi pembelajaran kepada siswa. Walaupun demikian, metode demonstrasi tersebut juga memperlukan penjelasan secara lisan oleh guru supaya peserta lebih memahami materi yang disampaikan. Dalam metode demonstrasi para siswa hanya perlu memeperhatikan guru yang sedang menyampaikan materi. Dalam strategi pembelajaran menggunakan metode 
demonstrasi tersebut, dapat digunakan untuk mendukung keberhasilan strategi pembelajaran.

Pembelajaran dengan menggunakan metode demonstrasi lebih menarik para siswa, karena di dalam metode ini siswa tidak hanya mendengarkan/memperhatikan guru, tetapai juga melihat peristiwa yang terjadi. Dengan cara mengamati secara langsung siswa akan memiliki kesempatan untuk membandingkan antara teori dengan kenyataan yang ada di lingkungan. Dalam penyampaian materi menggunakan metode demonstrasi, guru mempersiapkan dahulu segala materi/bahan yang akan diajarkan kepada siswa supaya pada saat pembelajaran dimulai, guru dapat langsung menyampaikan materi tersebut dengan metode yang menarik.

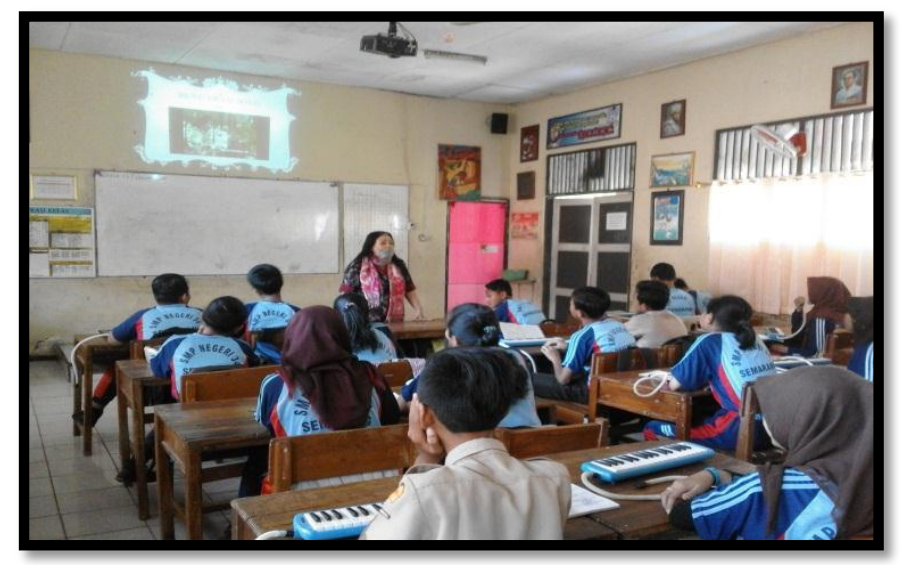

Foto 6, Observasi awal di kelas sebelum memulai penelitian ( Sumber : Ahadiah Februari, 2016 )

Berdasarkan hasil penelitian yang dilakukan pada hari jumat 19,26 Februari 2016 dan 4 Maret 2016, peneliti melihat bahwa guru memperdengarkan lagu keroncong melalui video yang di download melalui internet, dan video tersebut telah di buatnya kedalam powerpoint beserta materi-materi yang telah ditentukan dalam buku elektronik sekolah (BSE). Hal ini memang tidak sesuai 
dengan apa yang telah tercantum dalam RPP, maka peneliti menanyakan tentang alasan guru memilih menggunakan slide/powerponit dibandingkan $\mathrm{CD} / \mathrm{VCD} / \mathrm{kaset} / \mathrm{guru}$. Berikut petikan wawancara yang dilakukan peneliti dengan guru.

"Ya karena kemajuan teknologi mau tidak mau juga harus menuntut kita para guru untuk bisa menggunakan komputer, salah satu media yang menunjang pembelajaran sekarang ini ya ini menggunakan powerpoint, karena kebanyakan sekolah saat ini juga menyediakan proyektor/LCD bukan "tipe recorder atau televisi” yang dapat untuk memutar kaset atau VCD, bahkan para siswa lebih senang jika guru menggunakan media powerpoint seperti ini, dinilai lebih modern dan siswa lebih antusias mengikuti pelajaran, nah informasi yang didapat siswa dari vidio yang sudah diputar barusan lebih jelas, diantaranya melodi dari lagu itu sendiri, irama yang jelas dan lebih enak didengar tentunya, siswa jadi lebih paham untuk menganalisis sebuah lagu. Antara dinamika dan tempo lagu tentunya yang saya perdengarkan dan perlihatkan adalah lagu yang original dari penyanyi aslinya, agar siswa nantinya dapat mengetahui kwalitas musik-musik asli indonesia"

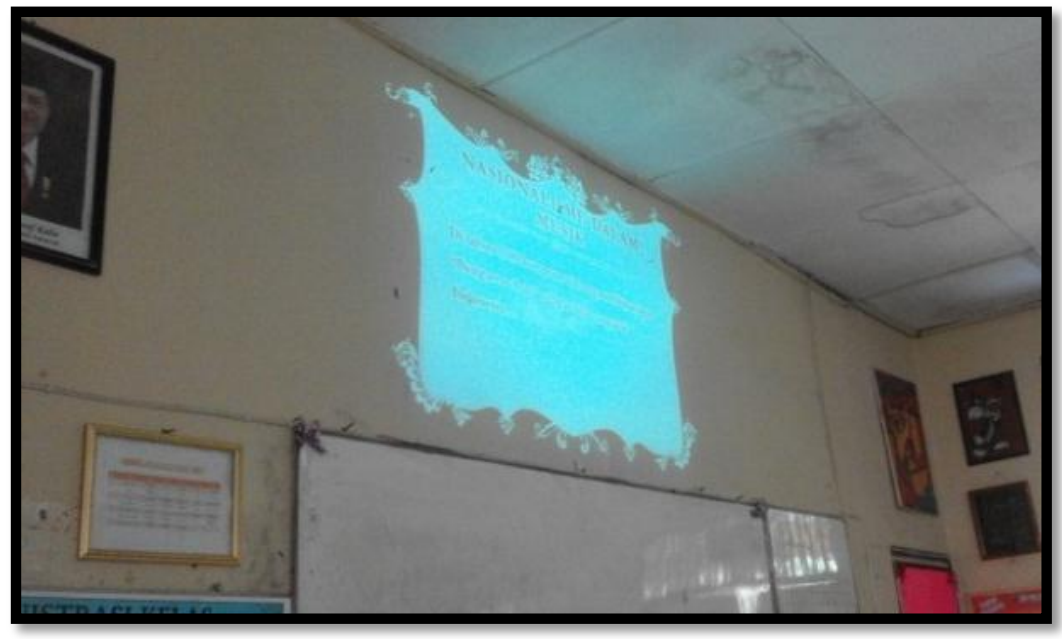

Foto 7, Penggunaan powerpoint sebagai media pembelajaran modern

( Sumber: Ahadiah Februari 2016 )

Setelah guru memperlihatkan/memperdengarkan materi yang dituangkan dalam bentuk audio visual guru melakukan tanya jawab tentang lagu yang sudah 
diperdengarkan, sesuai dengan apa yang sudah tertulis di RPP. Guru menanyakan kepada siswa tentang lagu yang telah diperdengarkan dan diperlihatkan sebelumnya melalui media audio visual yaitu powerpoint. Tentang judul lagu, dari mana asal lagu, siapa pencipta lagu, bagaimana irama dan melodinya. Dengan begitu guru melibatkan siswa secara penuh untuk dapat menemukan materi yang dipelajari dan mendorong siswa aktif di dalam kelas, dengan menjawab pertanyaan guru atau bertanya jika ada materi yang belum dipahami. Dalam kegiatan tanya jawab, guru cenderung lebih fleksible, tidak terlalu formal seperti pembelajaran pada umumnya. Kegiatan tanya jawab dilakukan seakan-akan guru seperti berbicara sehari-hari dengan seorang teman dan disela-sela kegiatan ini tidak selalu serius dan tidak membosankan.

Selain untuk menyenangkan siswa dengan cara seperti itu, diharapkan siswa tidak merasa takut, dapat mengikuti pembelajaran dengan hati yang senang, tenang, nyaman dan dapat menaruh rasa hormat guru seperti datang tepat waktu pada saat jam pelajaran hampir dimulai, disiplin dalam segala hal terutama pada saat pembelajaran seni musik walaupun guru tersebut santai dalam menyampaikan materi dikelas.

\subsubsection{Peralatan atau Media}

Peralatan atau media merupakan bahan pengajaran yang digunakan untuk menyajikan informasi kepada siswa. Dalam penelitian yang telah dilaksanakan 19 Februari 2016 peneliti dapat menjelaskan bahwa media yang digunakan guru saat melakukan kegiatan pembelajaran adalah laptop, LCD/proyektor dan speaker aktif karena sesuai dengan kemajuan jaman siswa tidak puas jika guru hanya 
menerangkan dengan berceramah atau bercerita saja, siswa butuh ada contoh konkrit yang bisa dilihatnya. Sebelumnya guru telah mempersiapkan materi dalam bentuk powerpointdi laptop lalu disambungkan ke LCD/proyektordan speaker aktif dengan begini para siswa lebih tertarik dengan pembelajaran yang disampaikan guru. Pada saat pelajaran praktek karena sekolah tidak cukup menyediakan alat-alat musik yang dibutuhkan banyak siswa, maka guru meminta siswa untuk membawa pianika, suling/recorder dan gitar jika diperlukan. Mediamedia tersebut yang biasa digunakan dalam menunjang pelajaran di kelas. Saat kegiatan praktek memainkan alat musik pianika, terlebih dahulu guru menayangkan sebuah vidio lagu kroncong Bengawan Solo karena sesuai dengan materi yang sedang berlangsung adalah musik nusantara maka guru memilih lagu keroncong Bengawan Solo sebagai materi.

Setelah siswa menonton vidio yang telah guru putarkan selanjutnya guru meminta siswa untuk memainkan ulang dengan menggunakan pianika dan recorder secara bersama-sama, peneliti melihat secara seksama cara guru menggunakan strateginya pada saat mengajarkan siswa dalam pelajaran seni musik. Siswa diharapkan dapat memainkan dengan benar lagu keroncong Bengawan Solo sesuai dengan partitur yang telah ada di buku paket yang sudah disediakan oleh sekolah, cara guru mengajarkan para siswa begitu telaten ketika ada siswa yang belum memahami tempo lagu antara not satu dan not berikutnya guru tidak akan lepas tangan melihat masalah tersebut, dengan cekatannya guru langsung mencontohkan lagu Bengawan Solo dengan tempo yang benar juga menggunakan pianiaka, setelah guru mencontohkan lalu para siswa mengikuti dan 
begitu seterusnya. Lalu guru akan dapat melihat dan menilai siswa mana yang cepat menangkap pelajaran dan mana yang masih kurang dalam merespon.

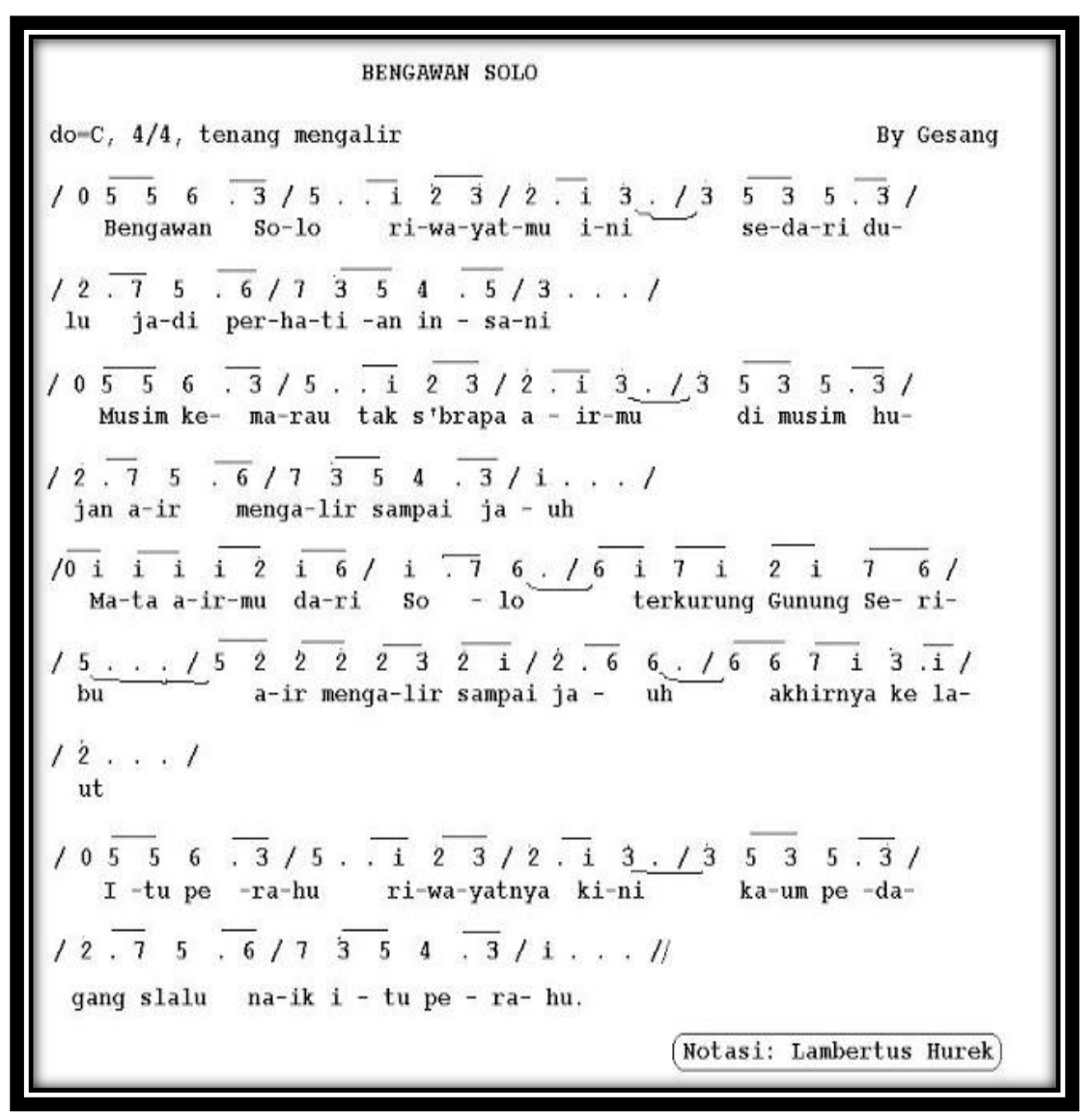

Peneliti menyimpulkan kegiatan ini sesuai dengan apa yang dikemukakan Sanjaya (2006:177-274) dalam bukunya yang membahas tentang beberapa strategi pembelajaran yang biasa digunakan guru dalam kegiatan belajar mengajar, yaitu secara tidak langsung guru telah menggunakan salah satu strategi dari Sanjaya yaitu strategi pembelajaran berbasis masalah (SPMB) yang artinya sebagai rangkaian aktivitas pembelajaran yang menekankan kepada proses penyelesaian masalah yang dihadapi secara ilmiah. Ciri utama dari SPMB, merupakan rangkaian aktivitas pembelajaran, artinya dalam implementasi SPMB ada sejumlah kegiatan yang harus dilakukan siswa. SPMB tidak mengharapkan siswa 
hanya sekedar mendengarkan, mencatat, kemudian menghafal materi pelajaran, akan tetapi melalui SPMB siswa aktif berfikir, berkomunikasi, mencari dan mengelola data, dan akhirnya menyimpulkan.

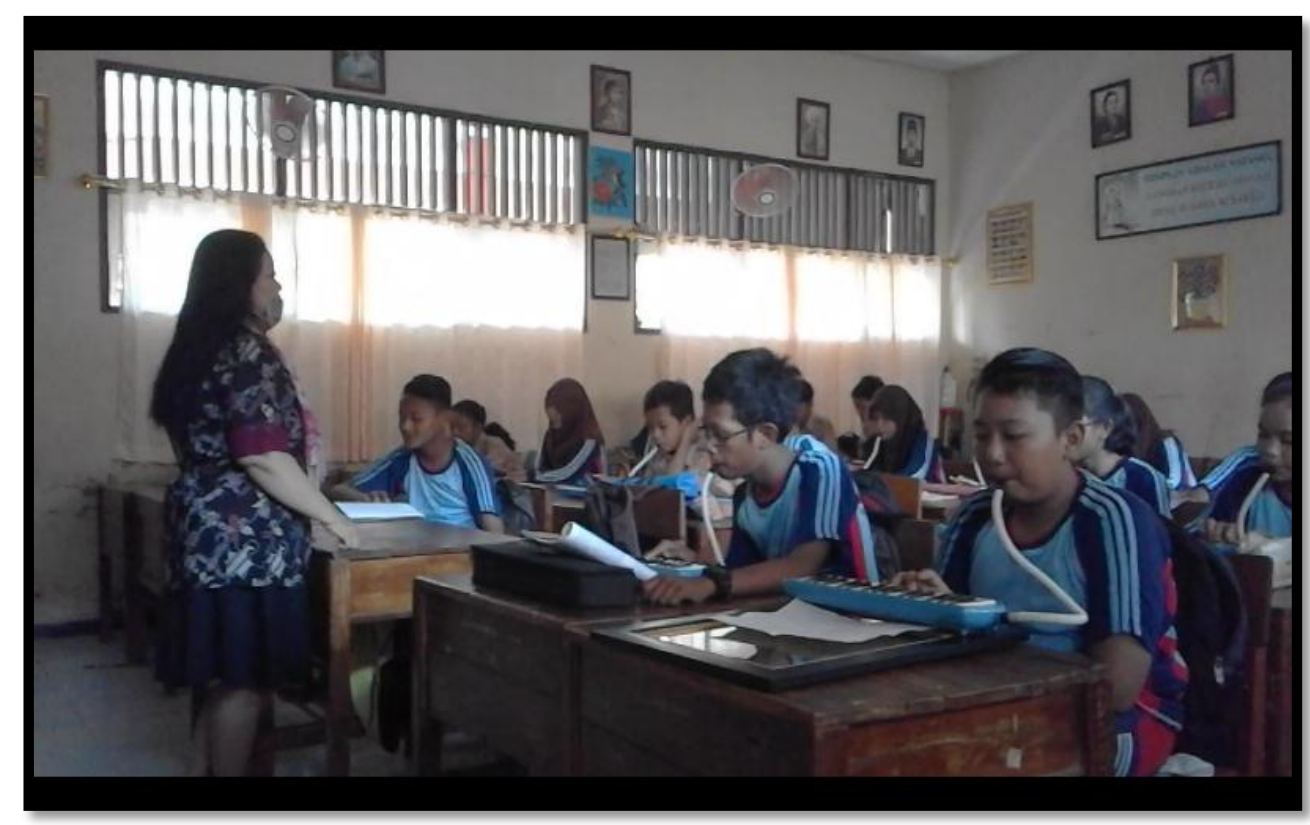

Foto 8, Kegiatan saat para siswa memainkan lagu menggunakan pianika

( Sumber: Ahadiah Februari 2016 )

\subsubsection{Bahan Serta Waktu}

Bahan ajar memiliki posisi yang sangat penting dalam kegiatan belajar mengajar, sebab bahan ajar adalah segala bentuk bahan yang digunakan untuk membantu guru dalam melaksanakan kegiatan belajar mengajar. Bahan yang dimaksud bisa berupa bahan tertulis maupun bahan tidak tertulis. Setelah dilaksanakan penelitian, diketahui kegiatan intrakurikuler seni musik di SMP N 34 Semarang hanya menggunakan buku paket sebagai pendamping pembelajaran atau bahan ajar oleh guru. Sedangkan siswa diwajibkan membawa instrument musik dalam bentuk recorder, pianika dan gitar jika diperlukan untuk dimainkan 
secara bersamaan dan dipandu oleh guru di dalam kelas. Model pembelajaran tersebut telah lama diterapkan oleh guru pengampu mata pelajaran seni budaya di SMP N 34 Semarang. Untuk rincian waktu yang tertera di RPP adalah 2x40 menit yang artinya 2 jam pelajaran dan masing-masing 1 jam pelajaran dihitung per 40 menit, dan gurupun sudah menerapkan waktu yang sesuai dengan RPP. Contoh RPP dapat dilihat dilampiran 10.

Hal tersebut dikarenakan bahwa pada RPP telah mencakup seluruh komponen-komponen strategi pembelajaran yang akan digunakan, sehingga guru mudah dalam melaksanakan strategi pembelajaran yang akan digunakan di dalam kelas. Adapula komponen-komponen yang tercantum di dalam RPP yaitu alokasi waktu, standar kompetensi, kompetensi dasar materi pembelajaran, tujuan pembelajaran, metode yang digunakan, susunan kegiatan pembelajaran yang harus dijalankan, sumber belajar, media serta alat atau bahan, dan cara evaluasi pembelajaran. Pada alokasi waktu, guru harus dapat memperhitungkan benarbenar pada saat menyampaikan materi pembelajaran dan di dalam RPP harus tercantum jelas alokasi waktu yang akan digunakan untuk setiap kegiatan dalam proses pembelajaran, sehingga materi pembelajaran dapat disampaikan guru dengan jelas dan terarah, contoh RPP dapat dilihat dilampiran 10.

Pada standar kompetensi dan kompetensi dasar materi pembelajaran, guru menuliskan sesuai dengan kurikulum yang terdapat pada silabus. Materi pembelajaran harus ditulis dengan jelas sesuai dengan tujuan yang ingin dicapai dalam proses pembelajaran tersebut. Media dan sumber belajar yang akan digunakan dalam proses mengajar juga harus tercantum dalam RPP. Pada 
komponen-komponen yang telah dipersiapkan guru seni musik tersebut juga diharapkan dapat mencantumkan komponen mengenai langkah-langkah yang akan dilakukan pada proses pembelajaran dengan menyertakan waktu untuk tiap-tiap kegiatan yang akan dilaksanakan pada pembelajaran tersebut. Untuk komponen terakhir yang harus tercantum dalam RPP yaitu evaluasi. Teknik instrumen dan contoh soal yang digunakan dalam pembelajaran juga harus tertulis dengan jelas pada komponen penilaian atau evaluasi ini. Dengan demikian RPP merupakan salah satu acuan bagi guru untuk memudahkan dalam menyiapkan strategi pembelajaran dengan baik.

\subsubsection{Komponen Pembelajaran Seni Musik di SMP Negeri 34 Semarang}

Pembelajaran Seni Musik di SMP Negeri 34 Semarang memiliki 5 komponen yang terdapat di dalamnya, komponen tersebut adalah sebagai berikut :

\subsubsection{Tujuan}

Tujuan pembelajaran merupakan perangkat kegiatan belajar mengajar yang direncanakan untuk mencapai tujuan yang disebut tujuan instruksional. Menurut B. Suryo Subroto (2002 : 15) tujuan instruksional adalah rumusan secara terperinci tentang apa saja yang harus dikuasai oleh siswa sesudah mengakhiri kegiatan instruksional yang bersangkutan dengan keberhasilan.

Berdasarkan materi di atas tujuan pembelajaran seni musik adalah untuk pengembangan bakat atau daya kreatif, sikap dan memberikan pengarahan atau pemahaman tentang teknik atau cara bernyanyi dan bermain musik yang harus diperhatikan. Mata pelajaran seni musik bertujuan pula untuk mengajarkan siswa saling bekerja sama antar individu dan tidak saling kuat antar individu karena di 
dalam bermain musik atau materi bernyanyi dibutuhkan kekompakan supaya nada atau suara yang dihasilkan dapat seimbang antara satu dengan yang lainnya.

Siswa lebih cepat paham atau mengenal karena setiap hari mereka melihat televisi maupun internet yang menampilkan berbagai macam kegiatan bermusik dan bernyanyi beserta informasinya dan penjelasannya. Selain mengajarkan kekompakan dan menumbuhkan rasa percaya diri dalam diri siswa pelajaran seni musik juga mengajarkan betapa nikmat keindahan musik, menghargai musikmusik nasional atau daerah, sehingga siswa memiliki rasa nasionalisme tinggi, dan dapat menerapkan pada kehidupan mereka sehari-hari dilingkungan masyarakan dengan cara saling menghargai satu sama lain.

\subsubsection{Materi}

Materi yang diberikan di dalam pelajaran seni musik di SMP Negeri 34 Semarang ditentukan oleh guru dan sekolah sesuai kebutuhan dan tingkat kemampuan siswa. Materi yang diberikan oleh guru pada saat jam pelajaran berlangsung di antaranya adalah lagu-lagu nusantara dan nasional yang sudah ditentukan di buku pegangan siswa atau bahkan lagu-lagu yang mudah dan sering didengar oleh para siswa. Setelah mereka menguasainya dan dirasa cukup, guru memberikan materi lagu satu tingkat lebih sulit dibanding dengan lagu sebelumnya. Guru selalu memberikan motivasi dan mengajari sampai siswa paham dan benar-benar menguasai. Materi adalah bahan ajar yang ingin di sampaikan dalam pembelajaran, dalam penyampaian materi pembelajaran hendaknya guru perlu memperhatikan secara sistematis dengan mempertimbangkan urutan keluasan materi dan kedalaman materi (Ekosiwoyo, 
1996:49). Menurut Uzer Usman, dan Lilis S. (1993 : 39) analisis materi pelajaran merupakan penguraian dari pokok bahasan kedalam bagian-bagian atau mata pelajaran dengan penelaah serta menghubungkan antara bagian untuk memperoleh pengetahuan dan pemahaman secara keseluruhan. Bahan pelajaran pada hakekatnya adalah isi dari mata pelajaran atau bidang studi yang diberikan pada peserta didik sesuai dengan kurikulum yang digunakan.

Guru mencari materi sebanyak-banyaknya. Hal tersebut juga bertujuan untuk mengembangkan kemampuan siswa dan menarik siswa agar senang mempelajari seni musik.

\subsubsection{Metode}

Metode adalah suatu cara untuk melakukan tindakan, Ramli (2008:8). Metode adalah suatu kerangka kerja untuk melakukan tindakan, atau suatu kerangka berfikir menyusun suatu gagasan, yang beraturan, terarah dan terkonteks, yang relevan dengan maksud dan tujuan, Sumaryanto (2007:9) Jadi metode adalah suatu kerangka kerja berupa proses, prinsip-prinsip dan prosedur untuk melakukan tindakan, atau suatu kerangka berfikir menyusun gagasan, yang beraturan, terarah dan terkonteks, yang relevan dengan maksud dan tujuan untuk mencari jawaban. Djramah (1997:48) menyatakan bahwa metode merupakan salah satu dari beberapa komponen pendidikan yang baku dalam sistem pembelajaran. Sedangkan menurut Hasibuan (1980:96) mendefinisikan metode sebagai alat yang merupakan bagian dari perangkat alat dan cara dalam pelaksanaan suatu strategi belajar mengajar. Efektif tidaknya penggunaan metode pembelajaran untuk mencapai tujuan sangatlah bergantung pada kemampuan 
seorang guru dalam meningkatkan motovasi belajar siswa, dan penggunaan metode yang tidak tepat dapat menjadi penghambat paling besar dalam proses pembelajaran, Pasaribu \& Simanjutntak, (1983:12). Metode dapat diartikan sebagai suatu cara atau teknik yang akan digunakan oleh pengajar dalam menyampaikan materi untuk mencapai tujuan pembelajaran, Daryanto dan Mulyo Raharjo, (2012:148). Dalam pembelajaran seni musik dikelas guru menggunakan beberapa metode yaitu antara lain metode ceramah, demonstrasi dan diskusi.

Dalam pelaksanaan metode ceramah guru sangat memperhatikan materi yang disampaikannya, langkah awal guru dalam menggunakan metode ini ialah merumuskan tujuan yang ingin dicapai apa yang dilakukan guru sesuai dengan yang dikatakan Sumaryanto, (2007:9). Guru mempersiapkan rumusan materi mana yang harus dikuasai siswa setelah proses pembelajaran dengan ceramah berakhir. Setelah merumuskan tujuan yang dilakukan guru selanjutnya ialah menentukan pokok-pokok materi yang ingin disampaikan guru kepada siswa, tidak lupa juga guru mempersiapkan ilustrasi-ilustrasi yang relevan untuk memperjelas informasi yang disampaikan.

Setelah metode ceramah dirasa cukup guru juga menggunakan metode demonstrasi, yang dilakukan guru dalam metode ini adalah guru mencontohkan bagaimana cara menyanyi dan bagaimana irama dan dinamik lagu Bengawan Solo yang memang dirasa perlu untuk dicontohkan tujuannya agar siswa tidak hanya mendengar dan membayangkan tetapi juga dapat melihat dan dapat dipraktekkan sendiri. Metode diskusi yang dimaksud disini adalah setelah guru menjelaskan dan memberi contoh materi dengan cara guru terlebih dahulu menyanyikan lagu 
Bengawan Solo dihadapan siwa, selanjutnya guru akan memberi tugas kepada siswa dan di sinilah metode diskusi digunakan, kegiatan tersebut sesuai dengan apa yang dikatakan, Daryanto dan Mulyo Raharjo, (2012:148) yang mengatakan bahwa metode adalah suatu cara atau teknik yang akan digunakan oleh pengajar dalam menyampaikan materi untuk mencapai tujuan pembelajaran.

Guru tidak hanya membiarkan siswa untuk melakukan diskusi hanya pada teman sekelasnya tetapi guru sangat terbuka jika ada siswa yang ingin menanyakan atau melakukan diskusi kepada guru tentang materi yang belum dipahaminya ataupun menyampaikan pendapatnya jika ada siswa yang kurang setuju dengan materi yang disampaikan oleh guru. Guru tidak membatasi ruang gerak siswa didalam kelas dengan begitu siswa tidak akan meras tertekan dalam mengikuti pelajaran seni musik.

\subsubsection{Media}

Media merupakan bahan pengajar dengan atau tanpa peralatan yang digunakan untuk menyajikan informasi kepada siswa. Fungsi media dalam pembelajaran yaitu: (1) Menangkap suatu objek atau peristiwa tertentu. Peristiwaperistiwa penting atau objek yang langka, dapat diabadikan dengan foto film atau direkam kemudian peristiwa itu dapat disampaikan dan digunakan manakala diperlukan. (2) Memanipulasi keadaan, peristiwa atau objek tertentu. Misalnya guru akan menjelaskan tentang candi Borobudur di dalam kelas maka guru dapat membuat miniature atau model candi tersebut dalam ukuran kecil. (3) Kesempatan belajar yang lebih merata. Dengan menggunakan berbagai video, audio, slide suara, dan sebagainya. Memungkinkan setiap orang dapat belajar dimana saja dan 
kapan saja. (4) Pengajaran lebih berdasarkan ilmu. Dengan menggunakan media proses belajar mengajar akan lebih terencana dengan baik sebab media dianggap sebagai bagian yang integral dari system belajar mengajar, oleh sebab itu sebelum pelaksanaannya guru dihadapkan kepada satu keharusan untuk mengidentifikasi dan karakteristik itu siswa sehubungan dengan menggunakan media.

Kemajuan ilmu pengetahuan dan teknologi, khususnya teknologi informasi, sangat berpengaruh terhadap penyusunan dan implementasi strategi pembelajaran. Melalui kemajuan tersebut para guru dapat menggunakan berbagai media sesuai dengan kebutuhan dan tujuan pembelajaran. Saat menjelaskan materi di dalam kelas media yang digunakan guru adalah laptop dan LCD/proyektor dan speaker aktif karena sesuai dengan kemajuan jaman siswa tidak puas kalo hanya diterangkan dengan ceramah saja, siswa butuh ada contoh konkrit yang bisa dilihatnya.

Sebelumnya guru sudah mempersiapkan materi dalam bentuk powerpoint lalu laptop disambungkan ke $L C D$ dengan begini para siswa lebih tertarik dengan pembelajaran yang disampaikan guru. Pada saat pelajaran praktek karena sekolah tidak cukup menyediakan alat-alat musik yang dibutuhkan, maka guru meminta siswa untuk membawa pianika, suling (recorder) dan gitar jika diperlukan. Media-media tersebut yang biasa digunakan guru dalam menunjang pelajaran dikelas, nantinya instrument-instrument musik tersebut yang akan digunakan para siswa untuk praktek bermain musik atau memainkan lagu. 


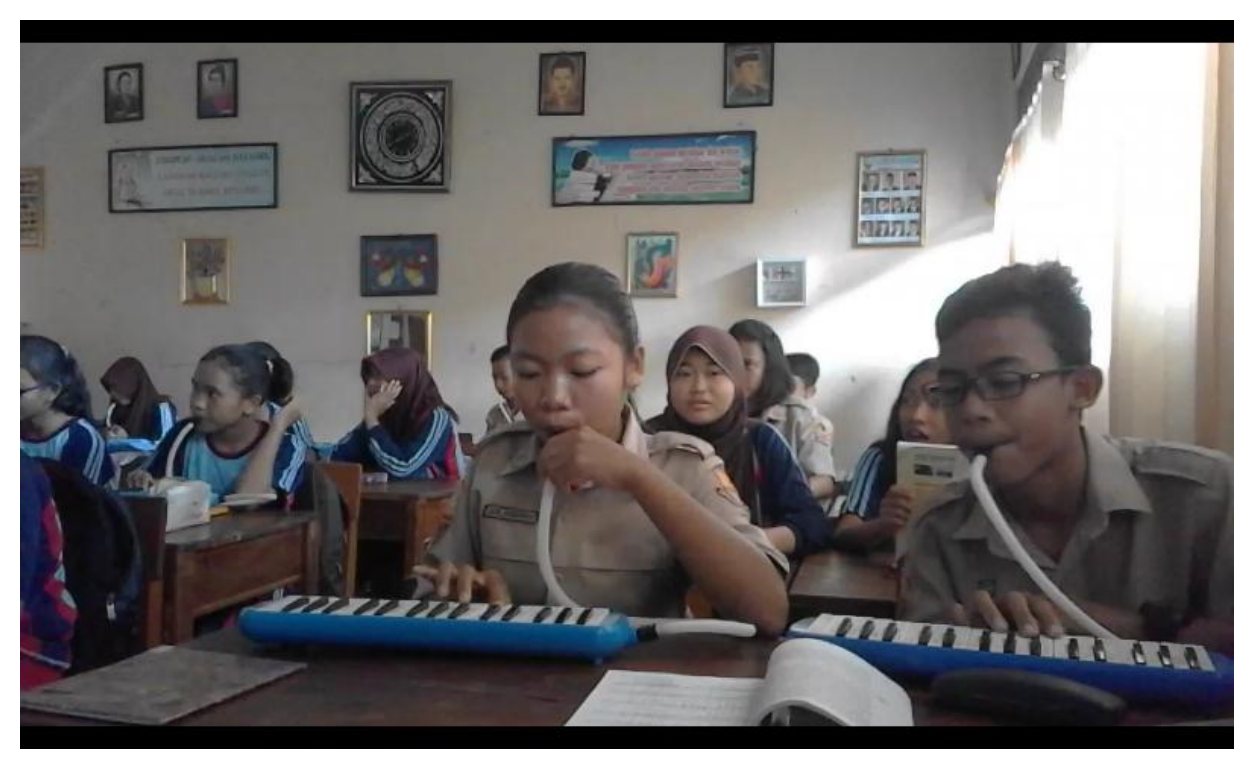

Foto 9, Kegiatan saat para siswa memainkan lagu menggunakan pianika

( Sumber : Ahadiah Februari 2016)

\subsubsection{Evaluasi}

Berdasarkan hasil evaluasi pada akhir kegiatan pembelajaran seni musik di kelas $8 \mathrm{C}$, guru dapat mengetahui tingkat penguasaan bahan pelajaran atau kecakapan masing-masing siswa. Selain itu evaluasi juga dapat digunakan guru sebagai alat untuk memperbesar motivasi belajar siswa, sehingga dapat mencapai prestasi belajar yang lebih tinggi. (Riyana Cepy: 2011: komponen-komponen pembelajaran:11-53:www.file. UPI. Edu/directori.com)

Guru melihat antusias dan keseriusan siswa dalam mengikuti pelajaran di kelas, apakah siswa rajin memperhatikan atau tidak, bagaimana semangat siswa dalam mempelajari materi yang diberikan oleh guru kepada siswa. Guru melakukan evaluasi kepada para siswa dengan cara tes wujud kerja/perbuatan yaitu dengan menyanyikan kembali lagu materi yang telah dipelajari sebelumnya. 
Guru melihat satu persatu kemampuan siswa dengan kegiatan ini guru dapat mengukur siswa mana yang serius dan tidak serius dalam mengikuti pelajaran, sama halnya materi yang dikatakan Aunrrohman (2012: 203).

Bahwa guru dapat mengukur kemampuan siswa pada setiap pertemuan, sedangkan yang dikatakan (Riyana Cepy: 2011: komponen-komponen pembelajaran:11-53:www.file. UPI. Edu/directori.com) ialah melalui evaluasi guru dapat mengetahui tingkat penguasaan bahan pelajaran atau kecakapan masing-masing siswa. Selain itu evaluasi juga dapat digunakan guru sebagai alat untuk memperbesar motivasi belajar siswa, sehingga dapat mencapai prestasi belajar yang lebih tinggi. Jika masih ada yang kesulitan dalam memahami materi guru tidak keberatan untuk melakukan bimbingan khusus kepada siswa yang belum paham. Evaluasi pula dapat memberikan motivasi dari pengampu kepada siswa sehingga bisa meningkatkan kemampuannya dalam proses pembelajaran akhir.

Setelah peneliti amati ternyata guru menggunakan beberapa metode menurut beberapa ahli, jadi dapat dikatakan guru juga sangat memperhatikan sekali materi dan pendapat-pendapat dari beberapa ahli.

\subsection{Inovasi Pembelajaran Seni Musik di SMP Negeri 34 Semarang}

Inovasi yang ingin dibahas peneliti dalam skripsi ini adalah inovasi pembelajaran yang digunakan guru dalam melaksanakan kegiatan belajar mengajar di dalam kelas. Inovasi pembelajaran yang diterapkan adalah dari model-model inovasi pembelajaran yang sudah ada sebelumnya. Inovasi 
pembelajaran yang dilakukan guru seni budaya SMP Negeri 34 Semarang bertujuan agar siswa aktif dan tertarik dengan materi yang diajarkan. Dalam pembahasan ini peneliti menggunakan beberapa model inovasi yang secara umum telah digunakan oleh para guru dalam melakukan kegiatan belajar mengajar di sekolah, antara lain : (1) Inovasi pembelajaran kuantum, (2) Inovasi pembelajaran kompetensi, (3) Inovasi pembelajaran kontekstual.

\subsubsection{Inovasi Pembelajaran Kuantum}

Inovasi pembelajaran kuantum sebagai salah satu model strategi dan pendekatan pembelajaran yang mengkonsentrasikan pada ketrampilan guru dalam mengelola pembelajaran merupakan buah karya dari Bobby DePorter (1999) dalam Udin Syaefudin (2009 : 125). Konsep, asas, dan strategi dari pembelajaran kuantum merupakan aspek-aspek yang harus dipahami oleh guru dalam mengimplementasikan model pembelajaran di sekolah agar konteks dan kontens pembelajaran yang bergairah, landasan yang kukuh, lingkungan yang mendukung, dan rancangan belajar yang dinamis. Prinsip menggunakan model pembelajaran kuantum terdiri dari : segalanya berbicara, segalanya bertujuan, pengalaman sebelum pemberian nama, akui setiap usaha, dan rayakan merupakan konsep utama pembelajaran kuantum untuk mewujudkan energi guru dan siswa dalam belajar.

\subsubsection{Suasana Yang Menggairahkan}

Penelitian menunjukkan, bahwa suasana kelas adalah penentu psikologis utama yang mempengaruhi kegiatan belajar. Pada dasarnya kelas adalah arena belajar yang dipengaruhi oleh emosi, itu sebabnya sangat disarankan guru 
berupaya menciptakan suasana kelas yang nyaman serta menyenangkan bagi siswa. Menurut peneliti tentang suasana kelas yang dibangun guru saat melakukan kegiatan pembelajaran sudah cukup baik karena cara pembawaan guru pada saat mengajar tidaklah terlalu menegangkan bagi para siswa, karena guru dapat memperlakukan siswa sebagai manusia sedrajat, guru juga dapat mengetahui pikiran, perasaan dan mengenal apa yang menjadi kesuakaan para siswa dalam kehidupannya.

Sebelum memulai pelajaran guru terlebih dahulu memberikan motivasi dan pengetahuan pendidikan karakter kepada siswa dengan cara mengobrol santai seakan-akan guru bertindak sebagai teman sebayanya, akan tetapi guru tetap memperhatikan posisinya. Pada saat sesi tersebut siswa bebas untuk bertanya apa saja yang ingin mereka ketahui, tujuannya untuk membuat rileks dan tidak membuat siswa berasumsi bahwa karakter guru itu tegas dan menyeramkan.

\subsubsection{Landasan Yang Kukuh}

Landasan yang kukuh adalah keyakinan terhadap kemampuan diri dan kemampuan siswa. Keyakinan atas kemampuan mengajar dan kemampuan siswa belajar akan menimbulkan hal-hal yang menakjubkan. Setiap kesepakatan, kebijakan, prosedur dan peraturan harus dilaksanakan bersama untuk memenuhi kebutuhan otak tentang struktur positif yang terarah. Pada intinya guru diharapkan dapat menjaga kestabilan siswa belajar dan membantu siswa mengaitkan pelajaran dengan gambaran masa depan mereka.

\subsubsection{Lingkungan Yang Mendukung}

Lingkungan kelas akan berpengaruh terhadap kemampuan siswa dalam 
memusatkan perhatian dan menyerap informasi sebanyak-banyaknya. Dengan demikian, dalam pembelajaran kuantum guru memiliki kewajiban menata lingkungan yang dapat mendukung situasi belajar dengan cara mengorganisasikan dan memanfaatkan lingkungan sekitar menggunakan alat bantu yang mewakili satu gagasan, pengaturan formasi siswa, pemutaran musik yang sesuai dengan kondisi belajar. Pengorkestrasian unsur-unsur dalam lingkungan sangat berpengaruh pada kemampuan guru untuk belajar lebih baik.

\subsubsection{Perencanaan Pengajaran Yang Dinamis}

Melalui perencanaan pengajaran guru dapat memasuki dunia siswa dalam proses pembelajaran. Disini diperlukan kemampuan guru memasuki dunia siswa baik sebelum maupun saat berlangsungnya pembelajaran dapat membawa sukses pembelajaran, karena membantu guru menyelesaikan pembelajaran dengan hasil belajar yang memuaskan. Pembelajaran kuantum memberikan strategi dan kiat tentang cara menjalin mitra dengan siswa sehingga guru merancang pembelajaran bermula kelompok besar, dilanjutkan dengan belajar dalam kelompok kecil, diakhiri dengan belajar secara perorangan.

\subsubsection{Inovasi Pembelajaran Kompetensi}

Inovasi pembelajaran kompetensi menunjukan pada usaha siswa mempelajari bahan pelajaran sebagai akibat perlakuan guru dalam mengelola pembelajaran yang menekankan pada kemampuan dasar yang dilakukan siswa pada tahap pengetahuan, ketrampilan, dan sikap.Pembelajaran kompetensi menekankan pencapaian standart kompetensi yang diuraikan menjadi kemampuan dasar yang diurai menjadi beberapa materi pelajaran yang cakupannya beberapa 
indikator. Pembelajaran kompetensi memiliki karakteristik khusus yang berbeda dengan pembelajaran lainnya, seperti apa yang dipelajari siswa bagaimana proses pembelajaran, waktu belajar, dan kemajuan belajar siswa secara individual.

Ketika siswa datang ke sekolah, maka guru harus beranggapan bahwa pengetahuan dalam kepala siswa tidaklah kososng. Mereka dari kebiasaan berbagai interaksi dengan anggota keluarganya, pergaulan dengan sesama temannya, dan dengan lingkungan hidupnya serta berbagai sumber bahan ajar seperti tontonan dari televise, radio, internet dan banyak pengetahuan dan informasi yang diperoleh.

Berbagai pengetahuan yang ada dalam kepala siswa itulah yang menjadi modal baginya untuk menerima, menyerap pengetahuan dan informasi baru yang disampaikan oleh para guru. Adapun prinsip yang diterapkan adalah mengajar atau membelajarkan siswa bukan pekerjaan sampingan, tetapi membutuhkan keahlian, kesungguhan, pengetahuan, keterampilan dan seni. Membelajar siswa bersifat unik sebab siswa individu manusia yang memiliki karakteristik yang kompleks.Setiap siswa memiliki potensi dan kecakapan berpikir dan ketrampilan yang berada, semua itu membentuk kepribadian yang khas dan unik, berbeda antara yang satu dengan lainnya. Guru dalam menerapkan model pembelajaran inovasi kompetensi ini ialah dengan memanfaatkan jam pelajaran yang sudah ditentukan oleh sekolah yaitu 2 jam pelajaran, dengan alokasi waktu $2 \times 40$ menit di setiap minggunya, dengan waktu yang sedemikian setiap siswa diharapkan dapat menguasai kompetensi standar, dan tidak hanya waktu yang perlu 
diperhatikan guru, secara garis besar aspek-aspek lain yang perlu diperhatikan guru dalam merancang dan melaksanakan kegiatan pembelajaran meliputi :

\subsubsection{Pengelolaan Ruang Belajar}

Ruang belajar merupakan tempat berlangsungnya kegiatan pembelajaran berbentuk ruang kelas. Selama berjam-jam siswa berada diruang kelas, selama itu pula terjadi interaksi guru dan siswa. Ruang tersebut harus tertata sedemikian rupa sehingga secara layak dapat melangsungkan kegiatan pembelajaran yang nyaman dan menyenangkan.

\subsubsection{Pengelolaan Siswa}

Siswa dalam suatu kelompok kelas biasanya memiliki kemampuan yang beragam, terutama dalam menerima sejumlah pengalaman belajar termasuk didalamnya materi yang harus dikuasai, karena itu guru hendaknya memahami tentang karakteristik siswa dalam kemampuan belajar.

\subsubsection{Pengelolaan Kegiatan Pembelajaran Kompetensi}

Kegiatan belajar siswa perlu dirancang sedemikian rupa sehingga sesuai dengan tingkatan kemampuannya. Seorang guru dituntut untuk menciptakan berbagai bentuk kegiatan pembelajaran, sehingga secara optimal mengembangkan kemampuan dirinya dengan berbagai pengalaman belajar.

\subsubsection{Pendekatan Kegiatan Pembelajaran Kompetensi}

Pendekatan merupakan langkah-langkah pembelajaran yang dapat dilakukan untuk mencapai tujuan secara efektif dan efisien, demi mencapi tujuan tersebut guru melakukan beberapa cara salah satunya yaitu memilih dan 
menetapkan sejumlah prosedur, metode, dan teknik kegiatan pembelajaran yang relevan dengan kebutuhan pengalaman belajar yang mesti ditempuh siswa.

\subsubsection{Sarana dan Sumber Belajar}

Sarana merupakan fasilitas yang mempengaruhi secara langsung terhadap keberhasilan siswa dalam kegiatan mencapai tujuan belajar. Sara yang paling membantu adalah sarana berupa media atau alat peraga. Media yang digunakan guru saat didalam kelas adalah buku BSE atau buku pegangan dari sekolah yang sudah ditentukan oleh pemerintah, media lainnya adalah laptop dan $L C D$, alat peraga yang digunakan adalah pianika dan recorder/seruling.

\subsubsection{Model Pendekatan Pembelajaran Kompetensi}

Proses pembelajaran berbasis kompetensi merupakan program pembelajaran yang dirancang untuk menggali potensi dan pengalaman belajar siswa agar mampu memenuhi pencapaian kompetensi yang telah ditetapkan. Maka dari itu guru diharuskan untuk memilih materi yang tepat untuk diberikan kepada siswa agar dapat untuk memecahkan permasalahan dalam kehidupan sehari-hari dengan menggunakan pengetahuan, sikap dan keterampilan.

\subsubsection{Inovasi Pembelajaran Kontekstual}

Inovasi pembelajaran kontekstual merupakan suatu model pembelajaran yang menekankan keterlibatan siswa setiap tahapan pembelajaran dengan cara menghubungkannya dengan situasi kehidupan yang dialami siswa sehari-hari sehingga pemahaman materi diterapakan dalam kehidupan nyata. Karakteristik pembelajaran kontekstual adalah pembelajaran merupakan proses pengaktifan pengetahuan yang sudah ada, belajar dalam rangka memperoleh dan menambah 
pengetahuan baru, pengetahuan yang diperoleh bukan untuk dihafal tetapi untuk diyakini dan diterapkan, memperaktikan pengalaman dalam kehidupan nyata, dan melakukan refleksi terhadap strategi pengembangan pengetahuan, Syaefudin (2009:162)

Pendekatan melalui model ini berkenaan dengan aspek kehidupan dan lingkungan, maka pendekatan pembelajaran ada keterlibatan pada siswa, makna, aktivitas, pengalaman dan kemandirian, serta konteks kehidupan dan lingkungan. Pembelajaran dengan fokus-fokus tersebut secara konprehensif tercantum dalam pembelajaran kontekstual.Siswa dalam pembelajaran kontekstual dipandang sebagai individu yang berkembang. Anak bukanlah orang dewasa kecil, melainkan organisme yang sedang berada pada tahap-tahap perkembangan.

Kemampuan belajar akan sangat ditentukan oleh tingkat perkembangan dan pengalaman mereka. Dengan demikian peran guru tidak lagi sebagai instruktur atau penguasa yang memaksakan kehendak, melainkan sebagai pembimbing siswa agar mereka dapat belajar sesuai dengan kemampuannya.

Setiap anak memiliki kecenderungan untuk belajar hal-hal yang baru dan penuh tantangan.Kegemaran anak adalah mencoba hal-hal yang bersifat aneh dan baru. Oleh karena itu, belajar bagi mereka mencoba memecahkan persoalan yang menantang. Guru berperan sebagai pemilih bahan-bahan belajar yang dianggap penting untuk dipelajari oleh anak. Guru membantu agar setiap siswa mampu mengaitkan antara pengalaman baru dengan sebelumnya, memfasilitasi atau mempermudah agar siswa mampu melakukan proses asimilasi dan akomodasi. 
Didalam inovasi pembelajaran kontekstual terdapat beberapa aspek atau point yang ingin dituju :

\subsubsection{Inovasi Perencanaan Pembelajaran Seni Musik}

Inovasi penyusunan perencanaan pada pembelajaran seni musik yang dilaksanakan di kelas 8C SMP N 34 Semarang sudah dilakukan dengan baik. Dalam melakukan inovasi perencanaan pembelajaran seni musik, guru sudah membuat perencanaan pembelajaran baik penyusunan silabus, tujuan pembelajaran, materi ajar, metode pembelajaran, kegiatan belajar mengajar, media pembelajaran serta evaluasi pembelajaran sudah disusun sesuai Permendiknas No.41 tahun 2007 tentang standar proses serta disesuaikan dengan kondisi sarana dan prasarana di sekolah dalam pelaksanaannya.

\subsubsection{Inovasi Strategi Pembelajaran Seni Musik}

Inovasi dalam strategi pembelajaran seni musik di SMP Negeri 34 Semarang yang dilakukan oleh guru sudah baik. Dalam menyampaikan materi, guru menggunakan metode pembelajaran yang inovatif yang bisa menumbuhkan minat dan kemauan siswa dalam mempelajari materi yang dianggap sulit.Strategi pembelajaran yang digunakan guru bervariasi diantaranya menggunakan metode ceramah dan diskusi. Metode yang digunakan saat mengajar berbeda-beda karena disesuaikan dengan materi ajar yang akan disampaikan. Penggunaan metode yang bervariasi selama proses pembelajaran ditujukan agar dapat menarik minat dan perhatian siswa terhadap pembelajaran seni musik serta siswa dapat mudah memahami materi yang disampaikan oleh guru, dengan begitu siswa akan menyukai pelajaran seni musik dengan sendirinya. 


\subsubsection{Inovasi Media Pembelajaran Seni Musik}

Inovasi media pembelajaran seni musik yang digunakan di SMP N 34 Semarang telah mengalami kemajuan. Hal ini terlihat dari cara guru menyampaikan materi seni musik kepada siswa. Siswa merasa tertarik dengan materi yang disampaikan karena guru menggunakan media pembelajaran seperti powerpointuntuk mempresentasikan materi kepada siswa. Media powerpoint terbukti dapat menarik perhatian siswa dan membuat siswa aktif bertanya jawab mengenai materi yang disampaikan oleh guru.

Selain itu guru tidak hanya terpaku menggunakan buku sebagai bahan ajar. Namun, guru juga memberi kebebasan siswa untuk mengakses materi pelajaran melalui internet, untuk menambah wawasan dan materi pelajaran untuk siswa pelajari, sehingga siswa semakin antusias mengikuti pembelajaran seni musik di kelas, tetapi guru akan selalu mengawasi dan memantau para siswa dalam penggunaan internet di dalam kelas agar para siswa tidak menggunakan internet secara berlebihan, metode ini dirasa lebih menarik dibanding guru selalu berbicara dan menerangkan didepan kelas.

\subsubsection{Inovasi Pengelolaan Kelas Pada Pembelajaran Seni Musik}

Inovasi pengelolaan kelas pada pembelajaran seni musik di SMP Negeri 34 Semarang sudah berjalan walaupun dalam bentuk yang masih sederhana dan disesuaikan dengan sarana dan prasarana yang ada di kelas. Inovasi tersebut di antaranya guru pada saat menyampaikan materi yang diajarkan menggunakan metode diskusi, maka bentuk susunan meja dan kursi yang ada di kelas diubah dalam bentuk kelompok-kelompok belajar, yaitu dengan cara siswa memilih 
kelompok sendiri atau ditentukan guru lalu mereka duduk secara berkelompok dengan menyusun meja kursi secara berhadap-hadapan. Dengan cara tersebut siswa akan secara mudah untuk berdiskusi dengan teman sekelompoknya.

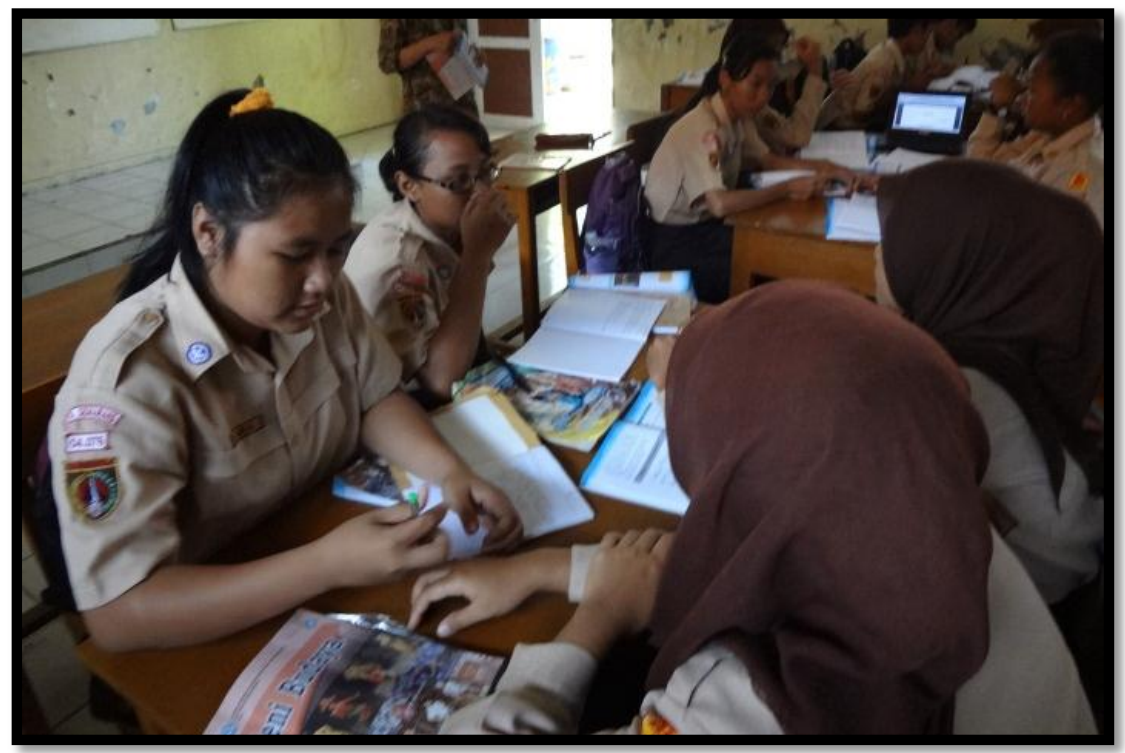

Foto 10, Kegiatan siswa saat berdiskusi

( Sumber : Ahadiah Februari, 2016 )

Guru akan memberikan pengarahan dan bimbingan kepada siswa jika masih ada yang belum bisa dan belum menguasai materi, dalam kegiatan diskusi tidak hanya guru yang selalu menjawab permasalahan siswa, tetapi guru akan melempar pertanyaan kepada siswa, jadi pertanyaan dari siswa akan dijawab oleh siswa lain atau temannya dan begitu seterusnya. Hal ini dilakukan supaya siswa memiliki pengalaman belajar bersama. 


\section{BAB V \\ PENUTUP}

\subsection{Simpulan}

Berdasarkan hasil penelitian dan pembahasan yang telah dipaparkan bab IV, dapat disimpulkan bahwa Strategi pembelajaran seni musik yang digunakan di SMP Negeri 34 Semarang adalah strategi pengelolaan kegiatan yang meliputi : (1) penyampain materi, (2) peralatan atau media, dan (3) bahan serta waktu. Selain beberapa strategi yang telah digunakan sebelumnya guru juga menggunakan strategi berbasis masalah (SPMB) sebagai metode pembelajaran didalam kelas.

Strategi yang digunakan dalam kegiatan belajar mengajar di SMP Negeri 34 Semarang dilaksanakan dengan seimbang, semua strategi dilakukan dengan cara mengalir begitu saja pada saat guru mengajar dikelas, apapun strategi yang digunakan di dalam kelas tujuannya adalah sama, para siswa diharapkan memahami dan menguasai materi yang sudah disampaikan.

Sedangkan model inovasi yang digunakan guru dalam menciptakan suasana pembelajaran baru dikelas ialah model inovasi pembelajaran kontekstual, tetapi juga tidak menutup kemungkinan bahwa guru juga menggunakan model inovasi lain seperti model inovasi pembelajaran kompetensi dan model inovasi pembelajaran kuantum. Inovasi pembelajaran kontekstual merupakan suatu model pembelajaran yang menekankan keterlibatan siswa setiap tahapan pembelajaran dengan cara menghubungkannya dengan situasi kehidupan yang dialami siswa sehari-hari sehingga pemahaman materi diterapakan dalam kehidupan nyata. 
Maka yang diharapkan guru setelah siswa keluar dari lingkungan sekolah adalah mereka dapat menerapkan sikap dan nilai-nilai baik dilingkungannya sehari-hari.

Inovasi yang digunakan guru di kelas adalah sesuai dengan apa yang sudah ada dan dikemukakan oleh para ahli, jadi guru hanya memahami isi materi lalu menyampaikannya di dalam kelas.

\subsection{Saran}

Berdasarkan hasil penelitian yang diperoleh dari uraian sebelumnya agar kegiatan belajar mengajar menjadi lebih baik dan semakin membuat siswa semakin meminati pelajaran seni musik, maka ada beberapa hal yang perlu ditingkatkan :

5.2.1. Sekolah lebih memperhatikan untuk pengadaan alat-alat musik yang dapat menunjang mata pelajaran seni musik, seperti pianika dan recorder/seruling alatalat musik sederhana yang sekiranya sering digunakan pada saat jam pelajaran seni musik, dan sekiranya sekolah mengadakan workshop tentang penggunaan strategi dan inovasi untuk pembelajaran di kelas, agar guru juga dapat menambah variasi dalam mengajar.

5.2.2. Agar dipertahankan strategi pembelajaran yang dipakai atau bahkan dapat dikembangkan lagi dan semoga dapat menciptakan inovasi-inovasi baru yang lebih menarik dan menyenangkan bagi para siswa.

5.2.3. Antara masing-masing individu lebih perlu bekerjasama, menghargai satu sama lain dan lebih percaya diri supaya hasil lebih maksimal dan dapat mencapai tujuan yang memperoleh prestasi. 


\section{DAFTAR PUSTAKA}

Anurrahman. 2012. Belajar dan Pembelajaran. Bandung : Alfabeta.

Asep Jihad, Abdul Haris. 2009. Evaluasi Pembelajaran. Yogyakarta. Multi Press.

B. Suryosubroto, (2002), Proses Belajar Mengajar Di Sekolah, Jakarta : Rineka Cipta

Bahari, Nooryan. 2008. Kritik Seni. Yogyakarta, Pustaka Pelajar

Bustomi, Suwaji.1992. Seni dan Budaya Jawa. Semarang: IKIP Semarang press.

Darsono, Max, dkk. 2000. Belajar dan Pembelajaran.Semarang: IKIP Semarang press.

Daryanto, Mulyo Rahardjo. 2012. Model Pembelajaran Inovatif. Yogyakarta: Gava Media

Dimyati, Mudjiono. 1999. Belajar dan Pembelajaran. Jakarta: Rineka Cipta.

Djamarah, Syaiful Bachri. 1997. Strategi Belajar Mengajar, Jakarta :Rineka Cipta.

Ekosiswoyo, R. 1996. Belajar dan Pembelajaran. Semarang: FIP Semarang.

Purnaningtyas, A., \& Suharto, S. (2011). PENGARUH KECERDASAN EMOSI TERHADAP PRESTASI BELAJAR SISWA MATA PELAJARAN SENI BUDAYA SMP. Harmonia: Journal Of Arts Research And Education, 10(1). doi:http://dx.doi.org/10.15294/harmonia.v10i1.56

Suharto, S. (2011). PENGEMBANGAN MATERI DAN KEGIATAN PEMBELAJARANNYA DALAM KURIKULUM TINGKAT 
SATUAN PENDIDIKAN BIDANG SENI MUSIK. Harmonia:

Journal Of Arts Research And Education, 8(3). doi:http://dx.doi.org/10.15294/harmonia.v8i3.780

Hamdani. 2011. Strategi Belajar Mengajar. Bandung: CV. Pustaka Setia.

Jamalus. 1998. Musik Dan Praktik Perkembangan Buku Sekolah Pendidikan Guru. Jakarta: CV. Titik Terang.

. 1998. Pengajaran Musik Melalui Pengalaman Musik. Jakarta: Proyek penyediaan Buku-buku Pelajaran Sekolah Guru, Departemen Pendidikan dan Kebudayaan.

Khanifatul. 2014. Pembelajaran Inovatif. Jogjakarta: Ar-ruzz Media.

Mack, Dieter. 2002. Komposisi Di Sekolah Sebagai Jalur Keluar Dari Dilema Pendidikan Musik, Semiloka Pendidikan Seni, Semarang, Pasca Sarjana UNNES

Moleong, Lexy. 1994. Metode Penelitian Kualitatif. Bandung: PT. Remaja Rosdakarya.

Moh.Uzer Usman dan Lilis Setiawati. 1993. Upaya Optimalisasi Kegiatan Belajar Mengajar. Bandung: Remaja Rosdakarya.

Pasaribuan, Simanjuntak. 1983. Proses Belajar Mengajar. Bandung: Tarsito.

Riyana Cepy: 2011: komponen-komponen pembelajaran :11-53: www.file.UPI. Edu/directori.com

Sa’ud, Udin Syaefudin. 2009. Inovasi Pendidikan. Bandung : Alfabeta

Sanjaya, Wina. 2006. Strategi Pembelajaran Berorientasi Standar Proses Pendidikan. Jakarta : Kencana Prenada Media Grup.

Setiawan. 2006. Pengertian Strategi. (http://globalisasi.wordpres.com)

Suharsimi, Arikunto. 1991. Prosedur Penelitian. Jakarta : Rineka Cipta.

Sukarman, Herry. 2003. Dasar-dasar dikdaktik \& Pembelajaran .Jakarta : Direktorat kependidikan. 
Sumaryanto, Totok F. 2007. Pendekatan Kuantitatif dan Kualitatif Dalam Penelitian Pendidikan Seni. Semarang: UNNES PRESS.

Wikipedia, 2008. Strategi. (hhtp://id.wikipedia.org) 
Lampiran 1

INSTRUMEN PENELITIAN

\author{
STRATEGI DAN INOVASI PEMBELAJARAN PADA KELAS \\ INTRKURIKULER SENI MUSIK DI SMP NEGERI 34 SEMARANG
}

Pedoman Observasi, Wawancara, dan Studi Dokumentasi

\title{
1. Pedoman Observasi
}

\subsection{Setting}

1. Dimana letak lokasi SMP N 34 Semarang?

2. Apa sarana dan prasarana yang dimiliki SMP N 34 Semarang untuk mendukung kegiatan belajar mengajar ?

3. Bagaimana keadaan guru dan karyawan di SMP N 34 Semarang ?

4. Bagaimana bentuk denah dan kondisi lingkungan SMP N 34 Semarang ?

\subsection{Pelaku}

Peneliti mengobservasi siapa sajakah yang terlibat dalam kegiatan belajar mengajar di SMP N 34 Semarang.

\subsection{Tindakan}

Peneliti mengobservasi tentang tindakan atau strategi dan inovasi apa saja yang digunakan guru dalam kegiatan belajar mengajar dikelas.

\section{Pedoman Wawancara Kepada Kepala Sekolah, Guru Pengampu}

\section{Pelajaran Seni Musik dan Para Siswa Kelas 8C}

\subsection{Pedoman Wawancara Kepada Kepala Sekolah SMP N 34 Semarang ?} Narasumber :Kepala Sekolah SMP N 34 Semarang 
1. Sejak kapan Bapak menjadi kepala sekolah si SMP N 34 Semarang ?

2. Sejak sekolah ini didirikan, ada berapa dan siapa saja kepala sekolah yang pernah menjabat di SMP N 34 Semarang ini?

3. Berapa jumlah guru yang mengajar di SMP N 34 Semarang ?

\subsection{Pedoman Wawancara Kepada Guru Pengampu Mata Pelajaran Seni}

\section{Musik}

Narasumber : Guru Pengampu Mata Pelajaran Seni Musik di SMP N 34 semarang

1. Sejak kapan Ibu menjadi guru Seni Musik di SMP N 34 Semarang ?

2. Bagaiman proses kegiatan belajar mengajar seni musik saat dikelas ?

3. Selama ini strategi apa yang Ibu gunakan saat mengajar seni musik dikelas ?

4. Mengapa diperlukan strategi pembelajaran saat mengajar didalam kelas ?

5. Perencanaan apa yang Ibu buat sebelum memulai kegiatan belajar mengajar dikelas ?

6. Bagaimana cara penyampaian materi ke para siswa di kelas ?

7. Saat ini sampai manakah materi seni musik yang sedang diajarkan ?

8. Metode apa yang Ibu gunakan dikelas agar siswa tertarik mengikuti kegiatan belajar mengajar saat mata pelajaran seni musik?

9. Inovasi apa saja yang Ibu ciptakan untuk kegiatan belajar mengajar dikelas?

10. Mengapa perlu di adakannya inovasi dalam pembelajaran dikelas ?

11. Bagaimana cara Ibu mengkomunikasikan inovasi pembelajaran ke siswa saat didalam kelas ?

12. Faktor apa sajakah yang menurut Ibu mempengaruhi hasil belajar siswa?

13. Bagaimana respon siswa terhadap mata pelajaran seni musik? 
14. Berapa jumlah siswa di kelas $8 \mathrm{C}$ ini?

15. Selama ini bagaimana nilai-nilai tugas yang Ibu berikan kepada siswa?

\subsection{Pedoman Wawancara Kepada Para Siswa kelas 8C di SMP N 34}

\section{Semarang}

1. Apakah pendapatmu tentang mata pelajaran seni musik di sekolah ?

2. Apakah kamu menyukai pelajaran seni musik ?

3. Mengapa kamu menyukai pelajaran seni musik ?

4. Pelajaran seni musik yang manakah yang paling kamu sukai ?

5. Selama ini adakah kesulitan yang kamu hadapi saat mengikuti mata pelajaran seni musik ?

6. Bagaimana perasaanmu saat mengikuti mata pelajaran seni musik di kelas ?

7. Selama ini bagaimana pendapatmu tentang cara guru mengajar dikelas saat mata pelajaran seni musik berlangsung ?

8. Apakah manfaat yang kamu dapatkan selama ini setelah mendapat pelajaran seni musik di sekolah?

\section{Pedoman Studi Dokumentasi}

1. Bagaimana gambaran kondisi gedung sekolah SMP Negeri 34 Semarang ?

2. Siapa sajakah tenaga pengajar dan staf karyawan yang ada di SMP Negeri 34 Semarang ?

3. Bagaimana gambaran kondisi kelas 8C di SMP N 34 Semarang?

4. Apakah sarana prasarana yang ada di kelas $8 \mathrm{C}$ sudah memadai ?

5. Bagaimana keadaan siswa di dalam kelas saat jam pelajaran seni musik ?

6. Siapa yang bertanggung jawab atas keadaan di kelas ? 
Lampiran 2

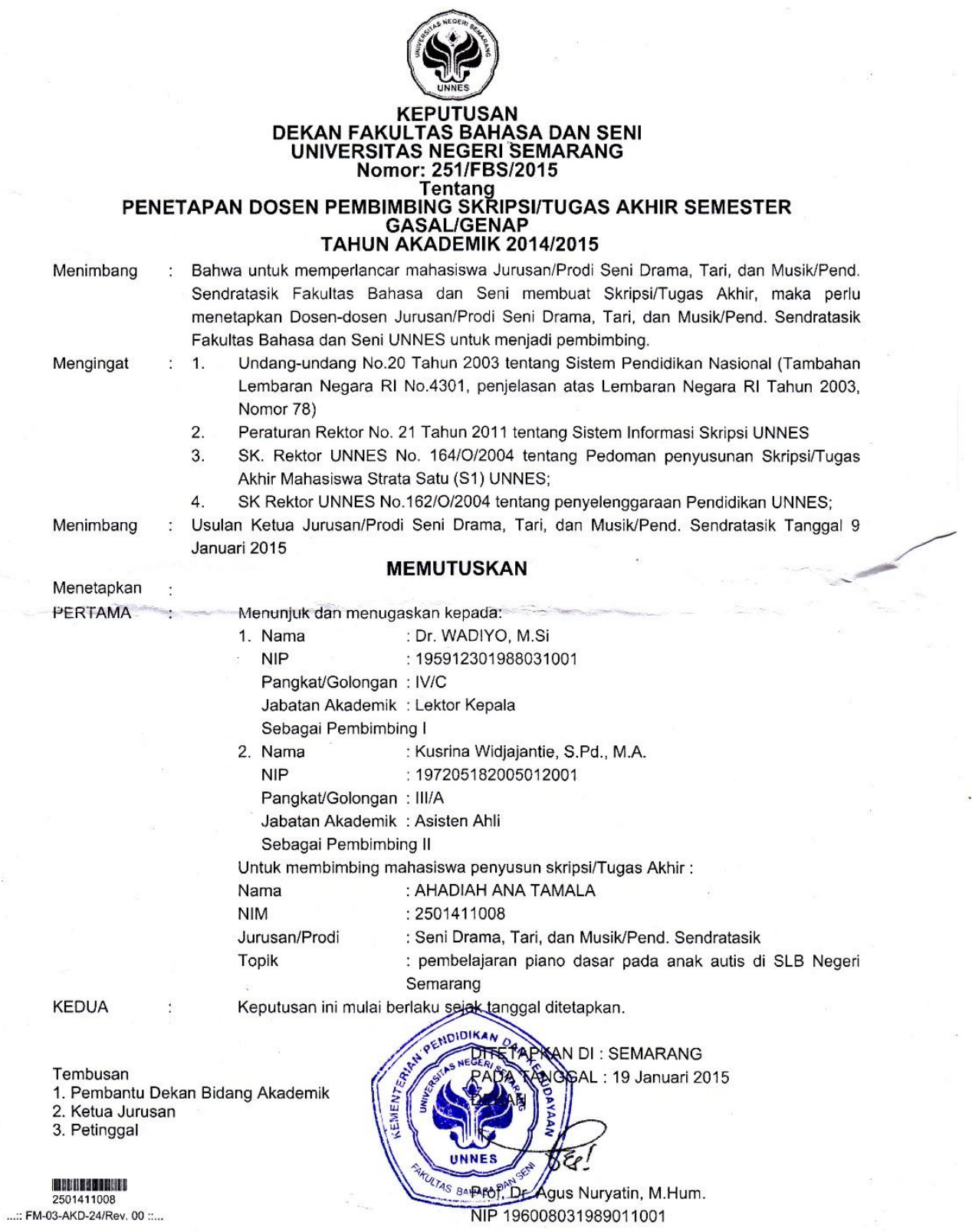




\section{Lampiran 3}

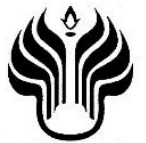

KEMENTERIAN RISET, TEKNOLOGI, DAN PENDIDIKAN TINGGI UNIVERSITAS NEGERI SEMARANG

FAKULTAS BAHASA DAN SENI

UNNES

Gedung B, Kampus Sekaran, Gunungpati, Semarang 50229

Telepon +62248508010 , Faksimile +62248508010 Laman: http://fbs.unnes.ac.id, Email: fbs@unnes.ac.id

Nomor : 277/UN37.1.2/LT/2016

Lamp. : :

Hal. : Permohonan Izin Penelitian

Yth. Kepala SMP Negeri 34 Semarang

di tempat

Dengan hormat kami beritahukan bahwa dalam rangka penyusunan skripsi mahasiswa kami,

nama : AHADIAH ANA TAMALA

nim : 2501411008

jurusan : SENDRATASIK

program studi : PENDIDIKAN SENI MUSIK

jenjang : S1

tahun akademik $\quad$ :2015/2016

judul : STRATEGI DAN INOVASI PEMBELAJARAN PADA KELAS INTRAKURIKULER SENI MUSIK KELAS 8C DI SMP NEGERI 34 SEMARANG.

akan mengadakan penelitian di SMP Negeri 34 Semarang, waktu pelaksanaan Januari 2016 s.d. Selesai. Untuk itu kami mohon Saudara berkenan memberikan izin kepada mahasiswa di atas untuk keperluan tersebut.

Atas perhatian dan kerja sama Saudara, kami sampaikan terima kasih.

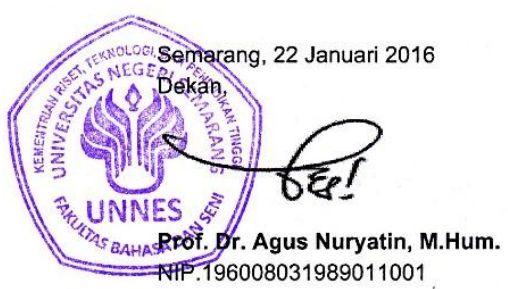

Tembusan:

1. Pembantu Dekan Bidang Akademik

2. Ketua Jurusan

3. Pertinggal

FM-05-AKD-24 
Lampiran 4

PEMERINTAH KOTA SEMARANG
DINAS PENDIDIKAN
SMP NEGERI 34 SEMARANG
Alamat $:$ Jl. Tlogomulyo Pedurungan Semarang, 军 6710576

SURAT KETERANGAN

No. 107 / 420 / 34.III / 2016

Yang bertanda tangan di bawah ini, Kepala SMP Negeri 34 Semarang menerangkan bahwa :

$\begin{array}{ll}\text { Nama } & : \text { AHADIAH ANA TAMALA } \\ \text { NIM } & : 2501411008 \\ \text { Progdi } & : \text { Pend. Sendratasik / Seni Musik / S1 } \\ \text { Fakultas } & : \text { Bahasa dan Seni } \\ \text { Perguruan Tinggi } & : \text { UNNES }\end{array}$

Yang bersangkutan benar-benar telah melaksanakan penelitian di SMP Negeri 34 Semarang dengan baik pada tanggal 12 Februari 2016 s.d. 4 Maret 2016 untuk memenuhi kebutuhan data penulisan skripsi yang berjudul "Strategi dan Inovasi Pembelajaran Intrakurikuler Seni Musik Kelas 8C di SMP N 34 Semarang".

Demikian Surat Keterangan ini dibuat untuk dapat dipergunakan sebagaimana mestinya.

Semarang, 4 Maret 2016

4.

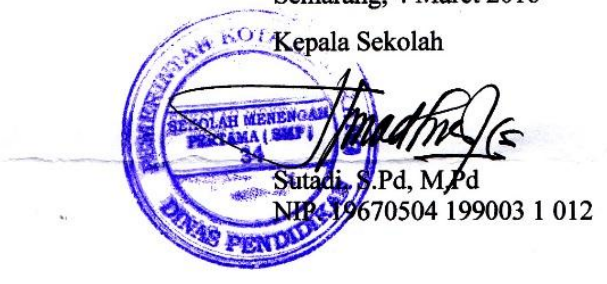




\section{Lampiran 5}

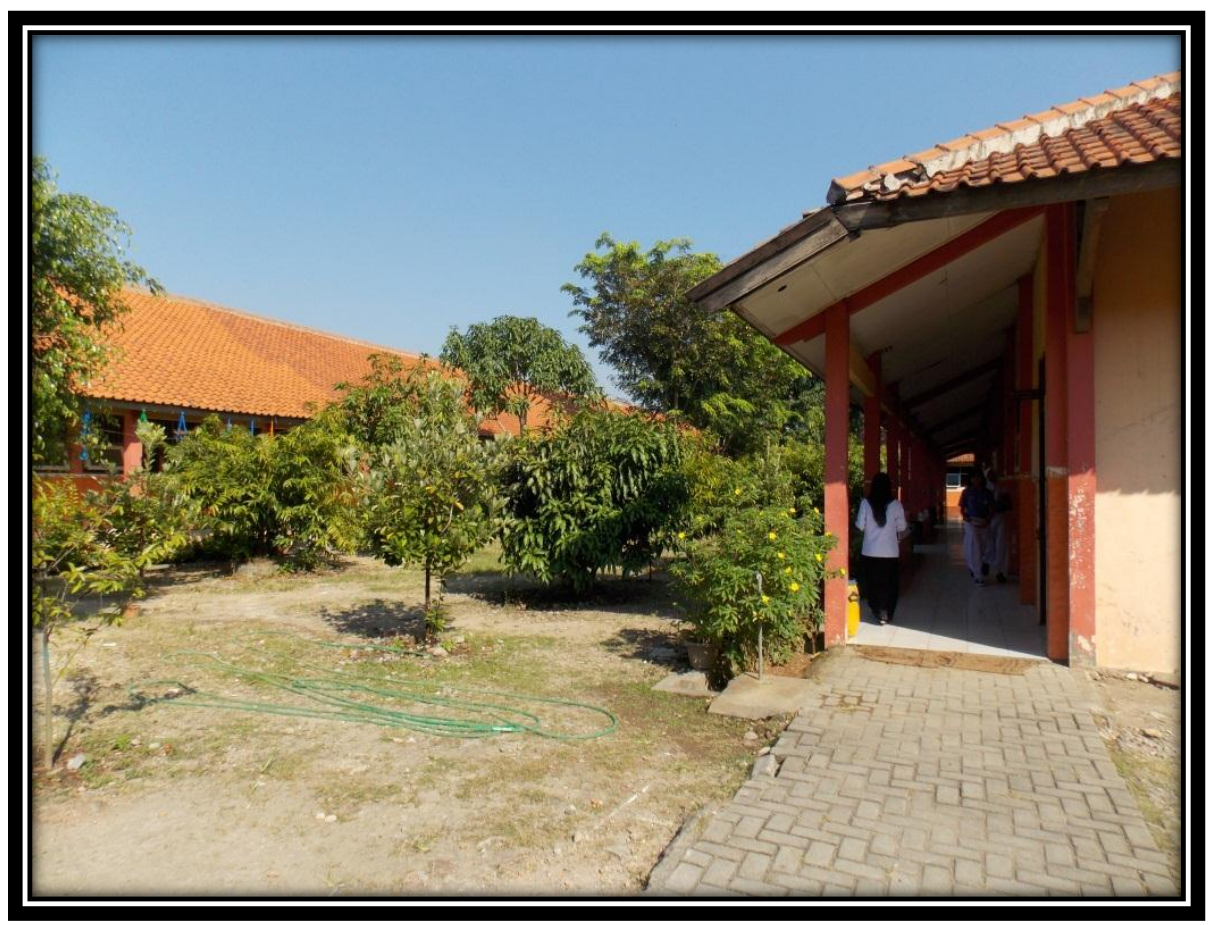

1. Area Halaman Depan Ruang Kelas 8

( Sumber : Ahadiah Ana Tamala, Februari 2016)

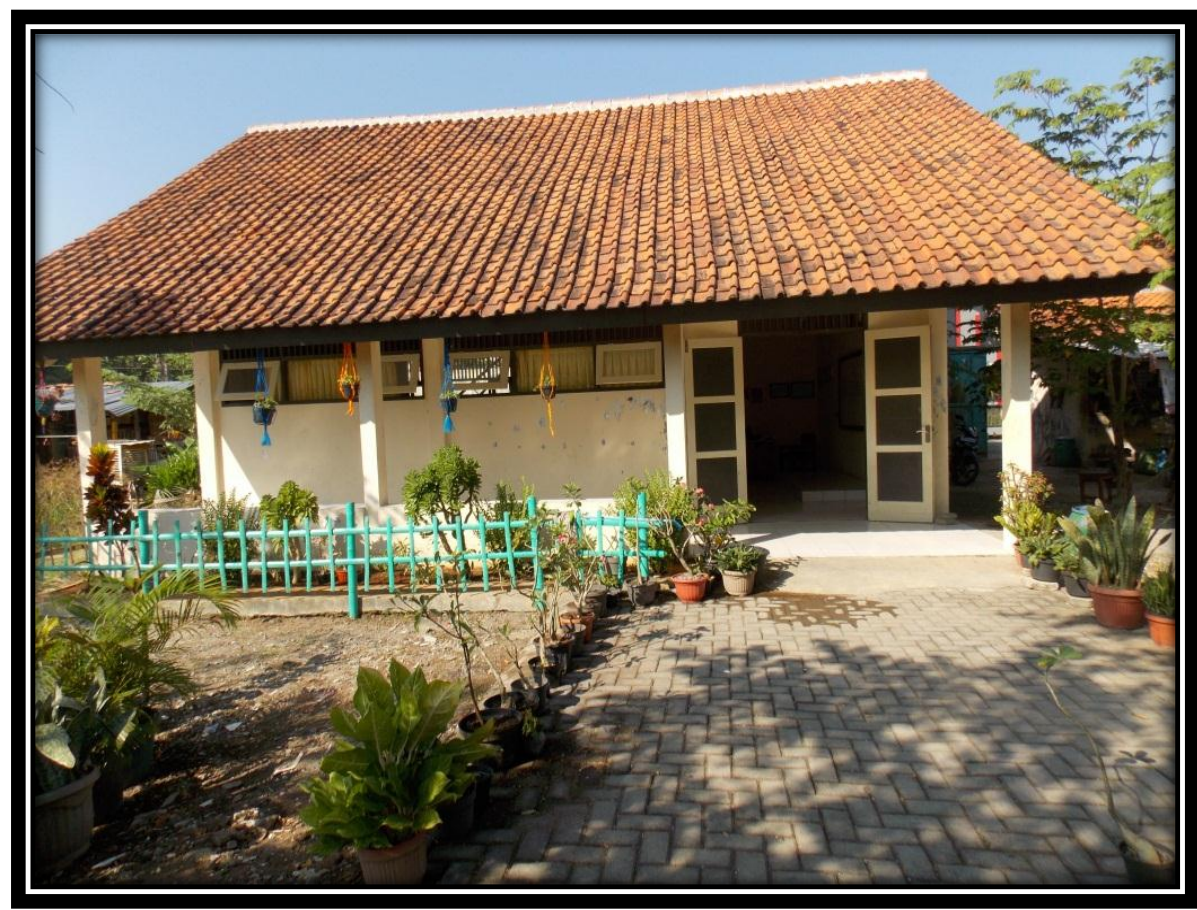

2. Kelas 7C Tampak Depan

( Sumber : Ahadiah Ana Tamala, Februari 2016) 


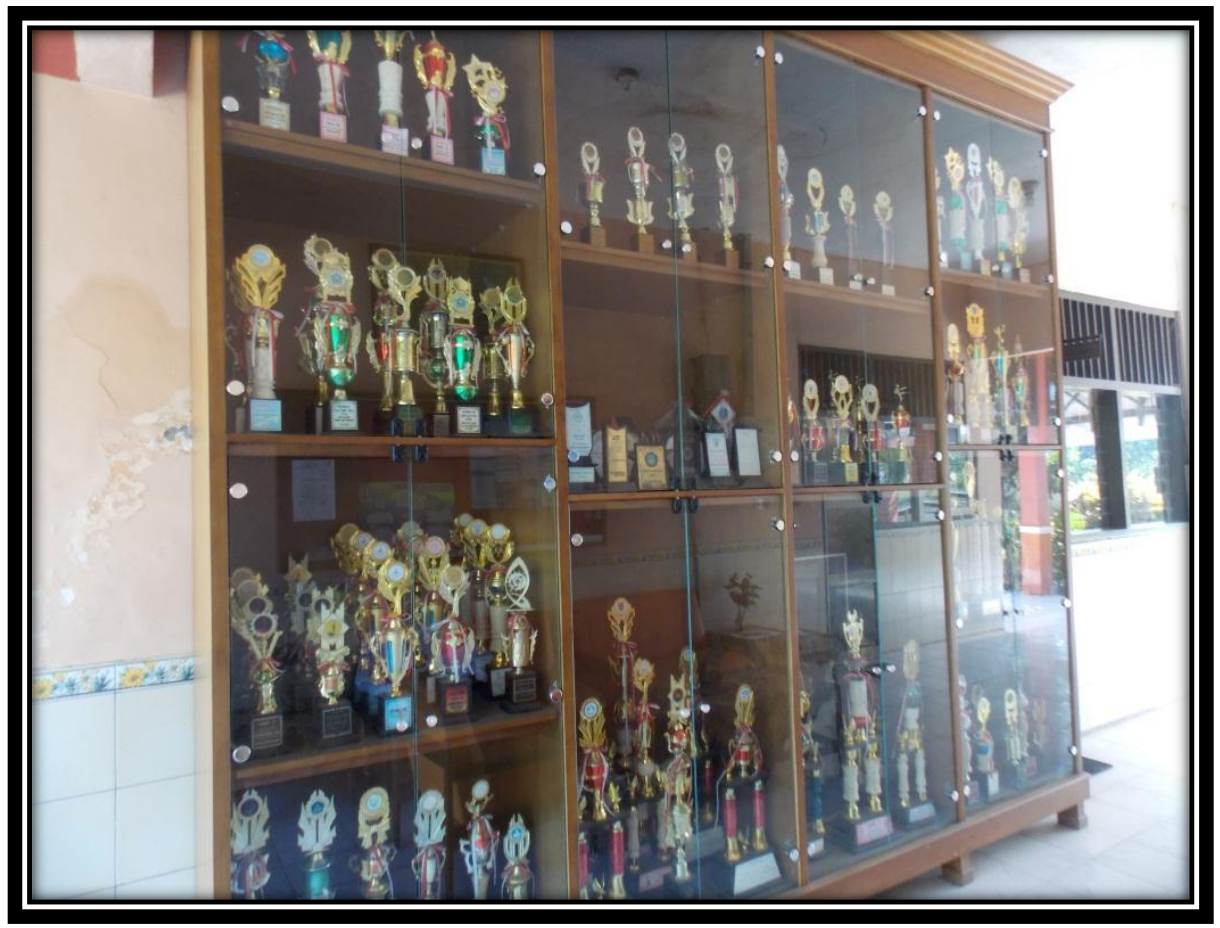

3. Almari Tempat Piala Penghargaan SMP N 34 Semarang ( Sumber : Ahadiah Ana Tamala, Februari 2016)

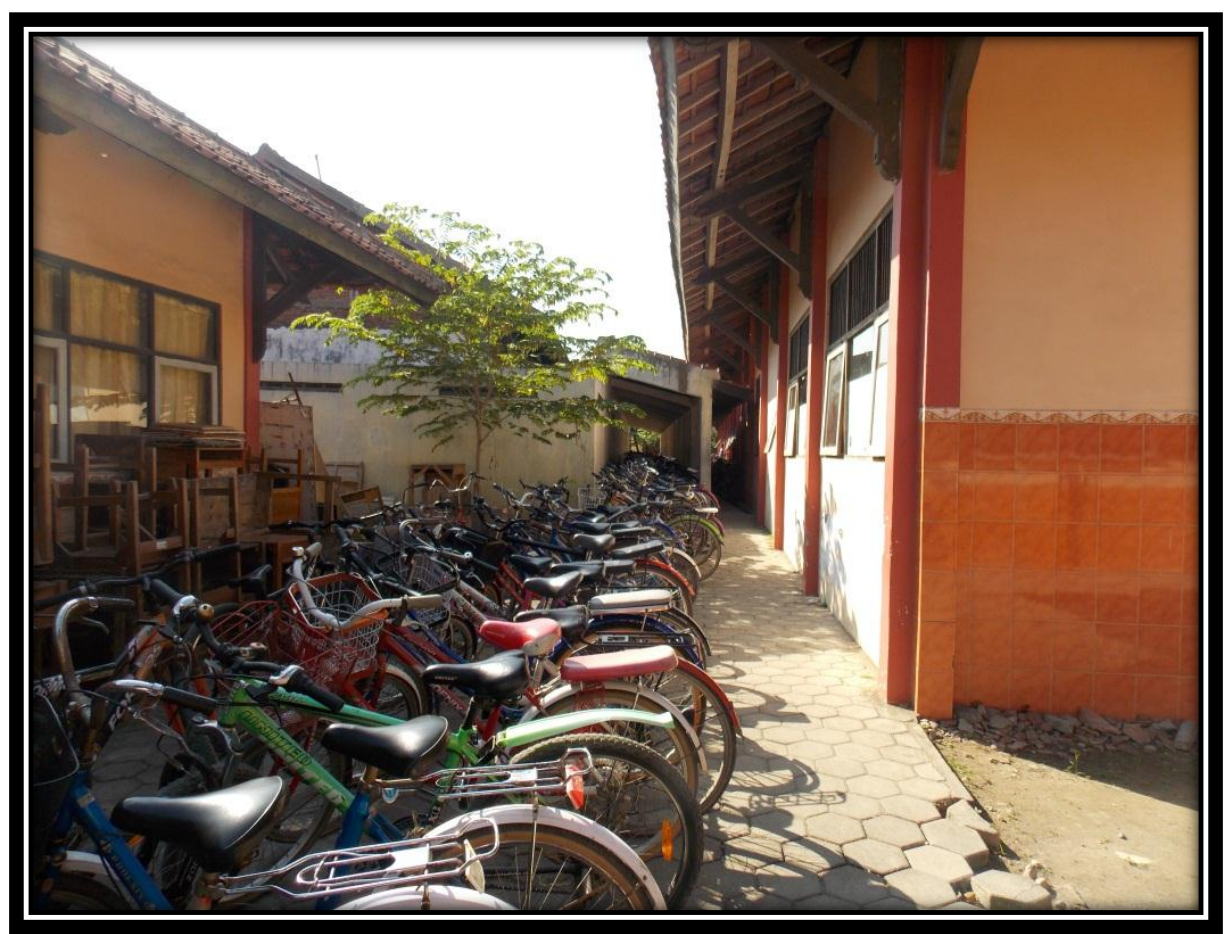

4. Tempat Parkir Siswa SMP N 34 Semarang

( Sumber : Ahadiah Ana Tamala, Februari 2016) 


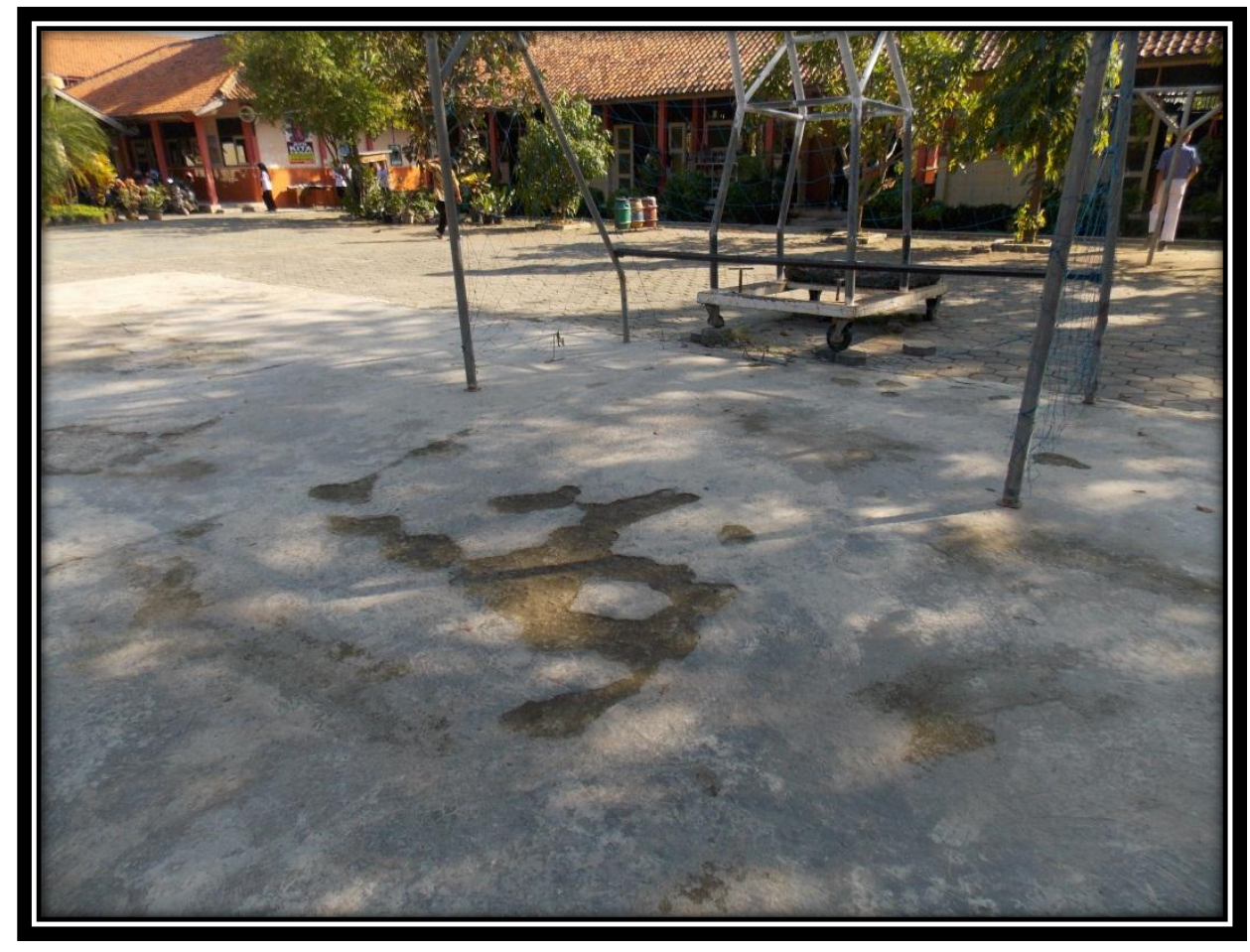

5. Lapangan Basket SMP N 34 Semarang

( Sumber : Ahadiah Ana Tamala, Februari 2016)

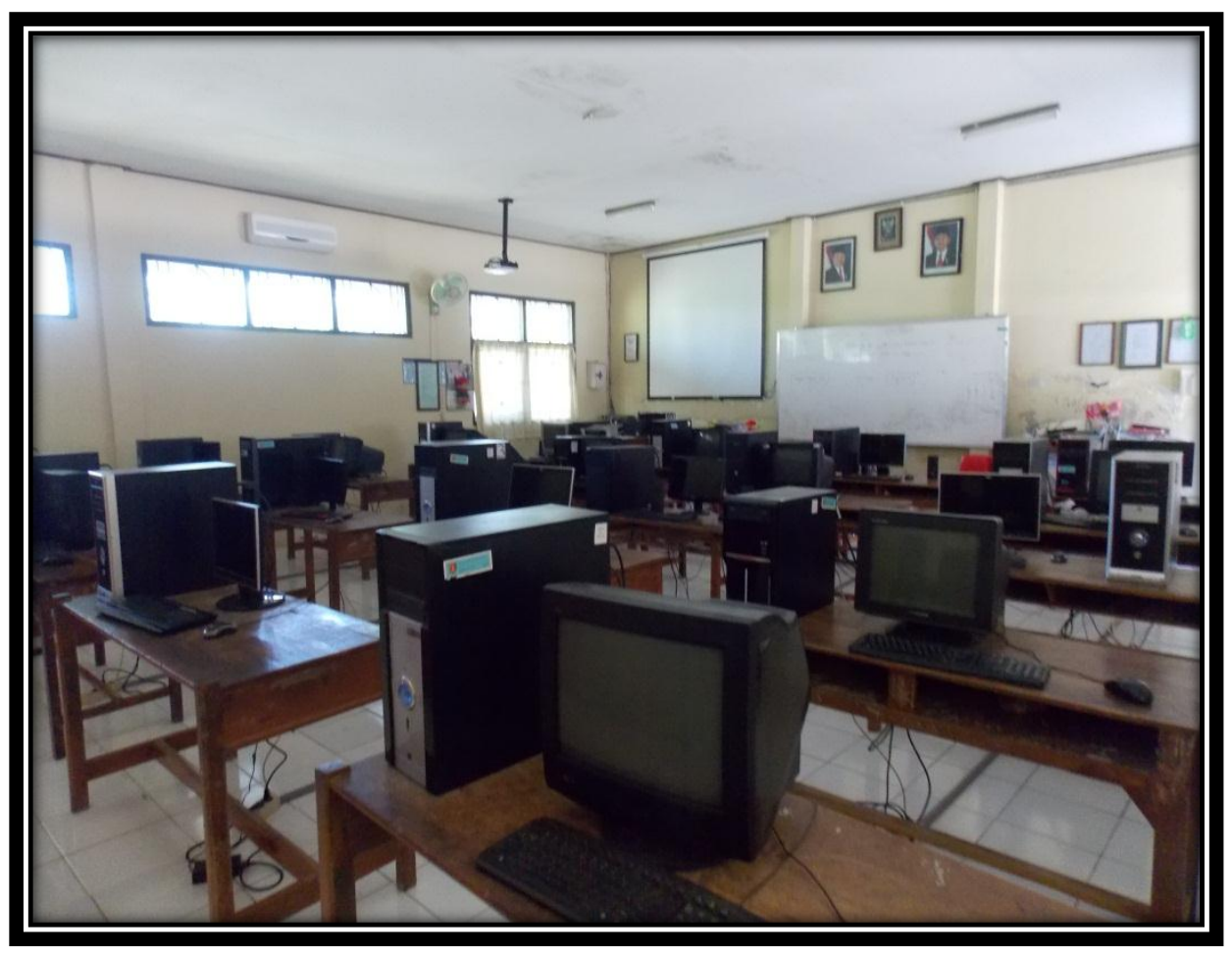

6. Ruang Komputer SMP N 34 Semarang

( Sumber : Ahadiah Ana Tamala, Februari 2016) 


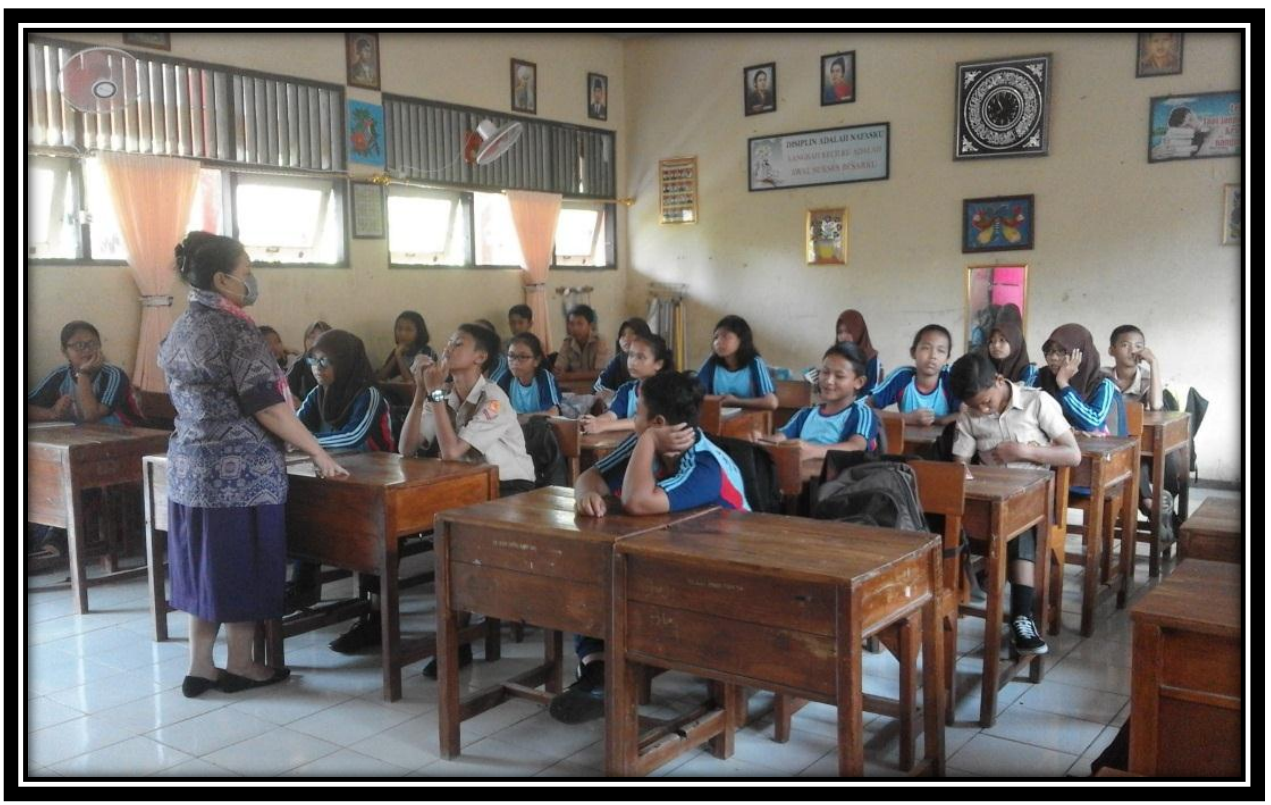

7. Kegiatan Pembelajaran Seni Musik

( Sumber : Ahadiah Ana Tamala, Februari 2016)

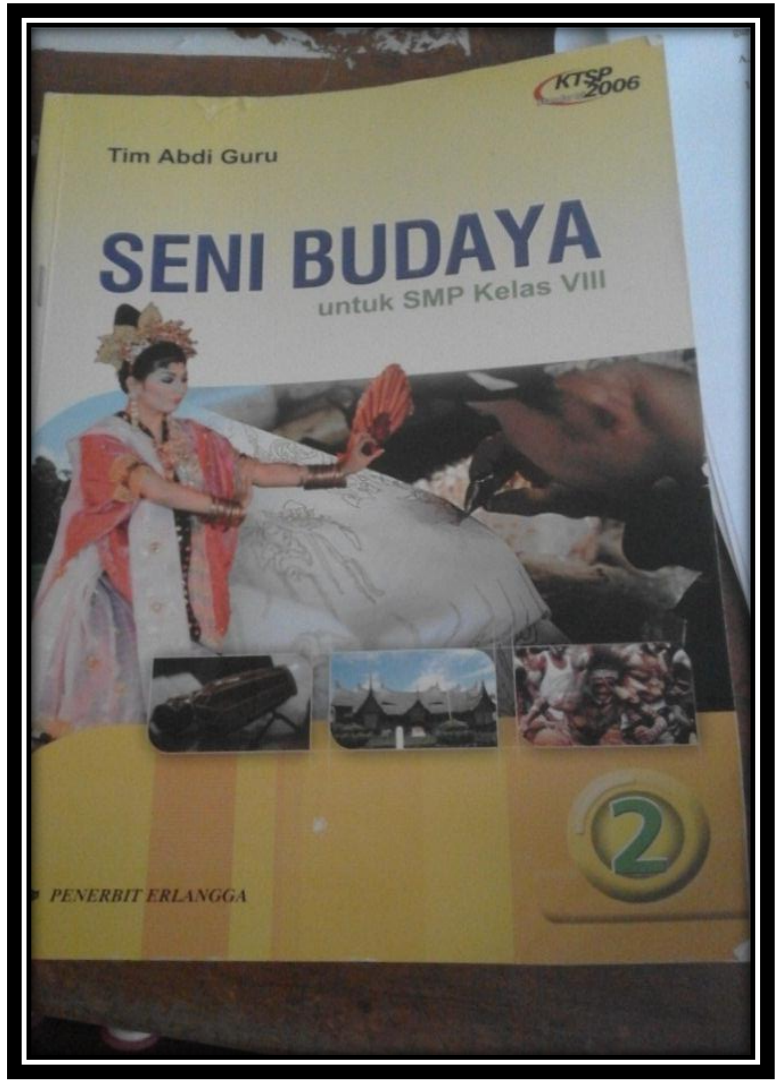

8. Buku Paket Seni Budaya Pegangan Siswa Kelas 8 ( Sumber : Ahadiah Ana Tamala, Februari 2016) 


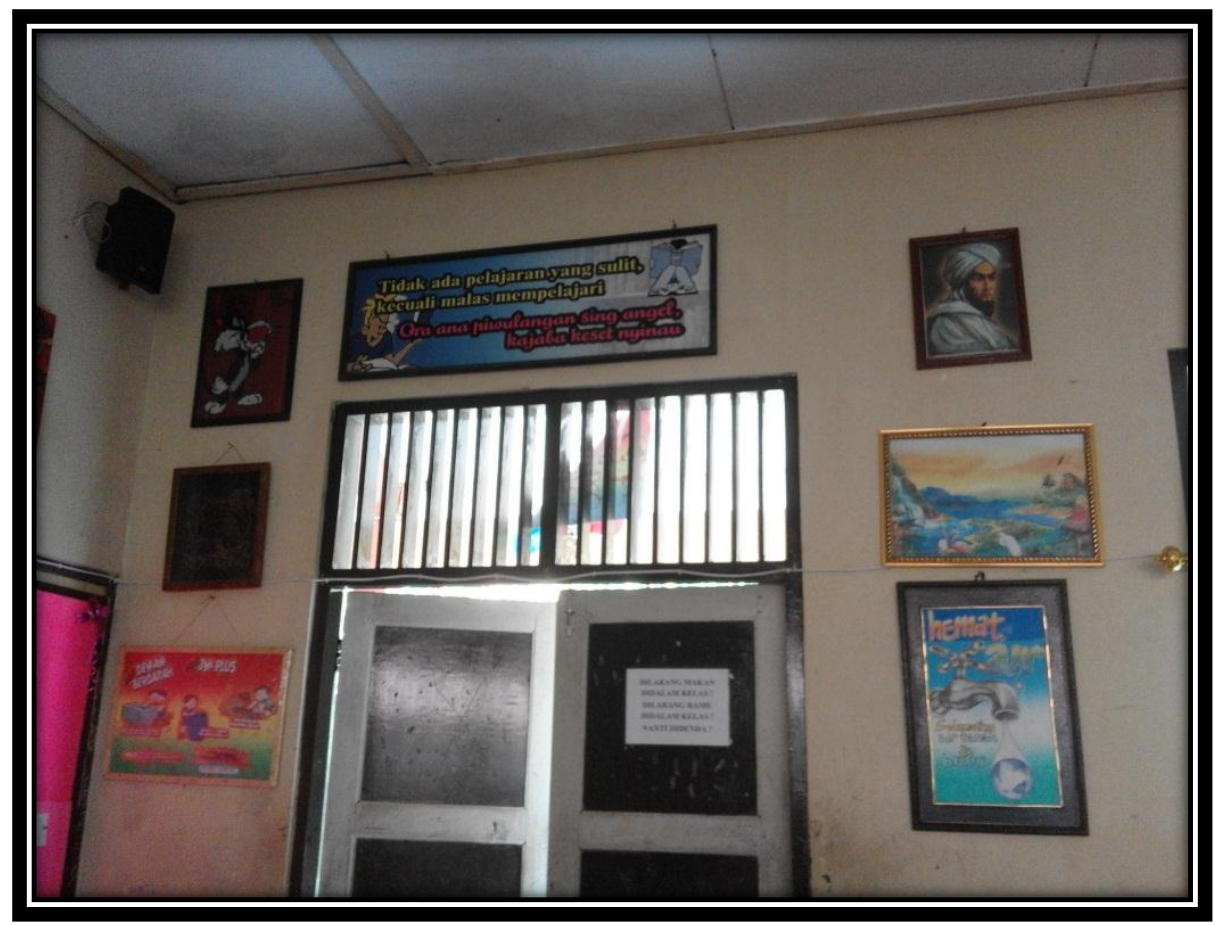

9. Hiasan Dinding Ruang Kelas 8C

( Sumber : Ahadiah Ana Tamala, Februari 2016)

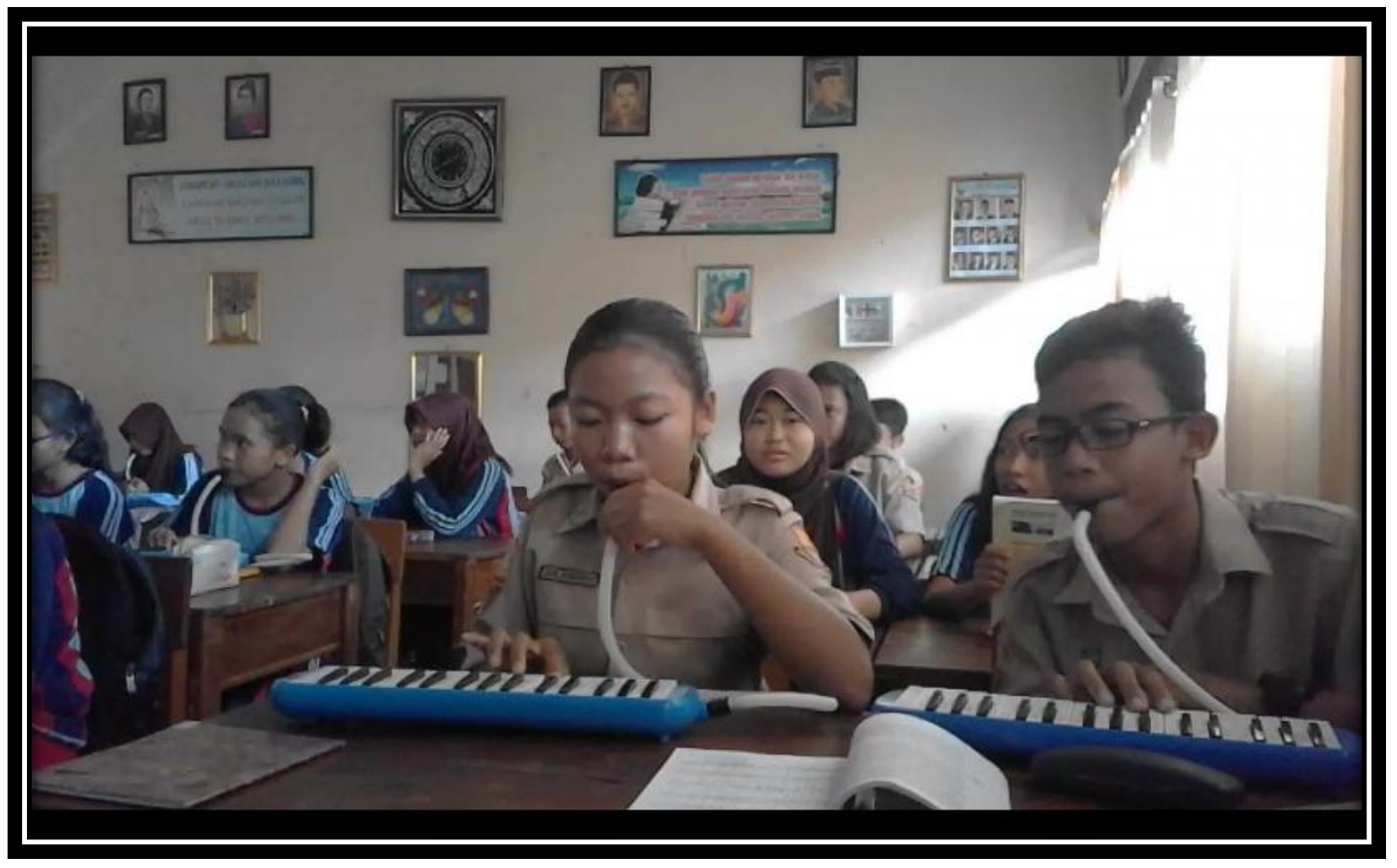

10. Kegiatan Siswa Saat Memainkan Pianika

( Sumber : Ahadiah Ana Tamala, Februari 2016) 
Lampiran 6

Daftar nama siswa-siswi kelas 8C SMP Negeri 34 Semarang

\begin{tabular}{|c|c|c|c|}
\hline \multirow{2}{*}{ NO } & \multirow{2}{*}{ NAMA SISWA } & \multicolumn{2}{|c|}{ JENIS KELAMIN } \\
\hline & & $\mathbf{L}$ & $\mathbf{P}$ \\
\hline 1. & ADHISTY ZAHRA SAPUTRI & $\mathrm{L}$ & \\
\hline 2. & ARLIA RAHMA HARIANTO & & $\mathrm{P}$ \\
\hline 3. & ARUM WULAN SAPUTRI & & $\mathrm{P}$ \\
\hline 4. & CALVIN FAISAL NUR RIZKI & $\mathrm{L}$ & \\
\hline 5. & CINTANIA SALSABELLA & & $P$ \\
\hline 6. & DENY CAHYO WIBISONO & $\mathrm{L}$ & \\
\hline 7. & DIVA MEDINA HAPSARI M & & $\mathrm{P}$ \\
\hline 8. & IKKE RATNA SARI & & $\mathrm{P}$ \\
\hline 9. & JANUAR USSAC FAKHRI & $\mathrm{L}$ & \\
\hline 10. & JESSENIA MAYSUN & & $\mathrm{P}$ \\
\hline 11. & LIA LESTARI & & $\mathrm{P}$ \\
\hline 12. & M. DAFFA NAIL NASHIF & $\mathrm{L}$ & \\
\hline 13. & MANDA FATMASARI & & $\mathrm{P}$ \\
\hline 14. & MENTARI PUTRI ATMALIA & & $\mathrm{P}$ \\
\hline 15. & MUCHAMAD HASAN BASRI & $\mathrm{L}$ & \\
\hline 16. & MUHAMAD FARHADUL ASAD & $\mathrm{L}$ & \\
\hline 17. & MUHAMAD KRISNA A & $\mathrm{L}$ & \\
\hline 18. & NOVI MUTIASARI & & $\mathrm{P}$ \\
\hline 19. & NUGROHO PRASETYO & $\mathrm{L}$ & \\
\hline 20. & NUR ADIB AFIUDIN HIDAYAT & $\mathrm{L}$ & \\
\hline 21. & PUDI AJI CAKRA ATMAJA & & $\mathrm{P}$ \\
\hline 22. & PUTRI RAHMAWATI & & $\mathrm{P}$ \\
\hline 23. & ROYHAN ALMAS ZULFIKAR & & $\mathrm{P}$ \\
\hline 24. & SALSABIIL MEIRANI PRIMASTI & & $\mathrm{P}$ \\
\hline 25 . & SHERLY OLIVIANI PUTRI & & $\mathrm{P}$ \\
\hline 26. & SUPRIYANTO & $\mathrm{L}$ & \\
\hline 27. & WAHYU DWI UTOMO & $\mathrm{L}$ & \\
\hline 28. & MUHAMMAD MALIK FAHAD & $\mathrm{L}$ & \\
\hline 29. & BELA ANANDA & & $\mathrm{P}$ \\
\hline
\end{tabular}


Lampiran 7

BEHGAWAN SOLO

do $=$ C, 4/4, tenang mengalir

By Gesang

$10 \overline{5} 56, \overline{3} / 5, \overline{1} \overline{3} / 2, \overline{1} 3, / 3 \overline{5} 5, \overline{3} /$ Bengawan so-lo ri-wa-yat-mu i-ni ${ }^{-}$se-da-ri du-

$/ 2 \overline{7} 5 \overline{6} / 7 \overline{35} 4 \overline{5} / 3 \ldots 1$

lu ja-di per-ha-ti -an in - sa-ni

$/ 0 \overline{55} 6, \overline{3} / 5, \bar{i} \overline{2} / 2, \bar{i} 3, / 3 \overline{5} 35, \overline{3} /$ Musim ke- ma-rau tak s'brapa a - ir-mu di musim hu-

$12 . \overline{7} 5, \overline{6} / 7 \overline{3} 54 \overline{3} / 1 . .1$

jan a-ir menga-lir sampai ja - uh

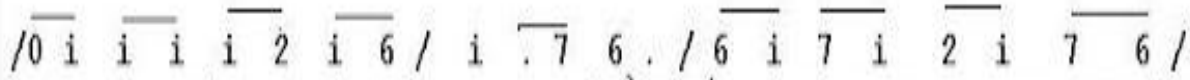
Ma-ta a-ir-mu da-ri so - 10 terkurung Gunung se- ri-

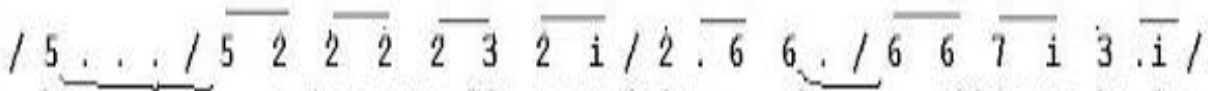
bu a-ir menga-lir sampai ja - uh akhirnya ke la-

$12 \cdot, 1$

ut

$10 \overline{5} 56 \overline{3} / 5, \overline{\mathrm{i}} \overline{2} / 2, \overline{\mathrm{i}} 3, / 3 \overline{5} 5, \overline{3} /$ I -tu pe -ra-hu ri-wa-yatnya ki-ni ka-um pe -da-

$12, \overline{7} 5, \overline{6} / 7 \overline{35} 4 \overline{3} / 1 \ldots 11$

gang slalu na-ik i - tu pe - ra- hu. 


\section{Anak Gembala}

\section{Tasya}

$E=d_{0}$

$\mid \begin{array}{lllllllllllll}34 & 31 & 2 & 34 & 3 & 1 & 2 & 34 & 5 & 3 & 6 & 54\end{array}$ A ku a da laha nak gem ba la se la lu ri angser ta

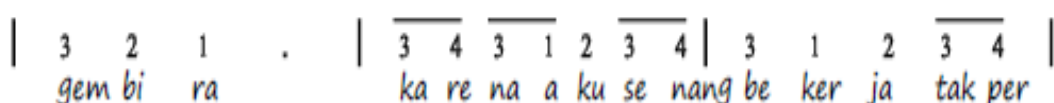

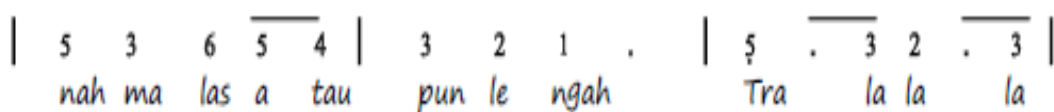

$\left|\begin{array}{lll}4 & 2 & 3\end{array}, \quad\right| \frac{5}{3} 2, \overline{3}|\overline{42} \overline{1} \quad 1$, la la la tra la la la la la la la la

$\mid \begin{array}{lllllllllllll}34 & 3 & 2 & 34 & 3 & 1 & 2 & 34 & 5 & 3 & 6 & 54\end{array}$ se ti ap hari ku ba wa ter nak ke pa dang rum put di ka

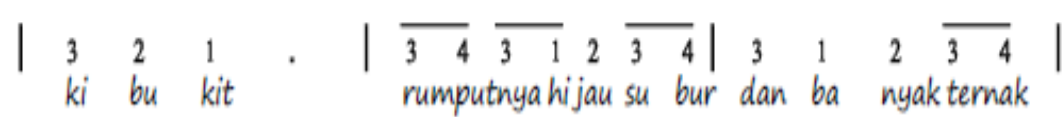

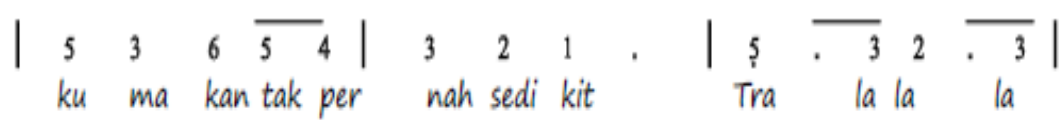

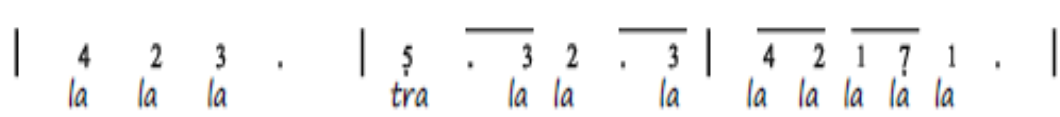




\section{Lampiran 8}

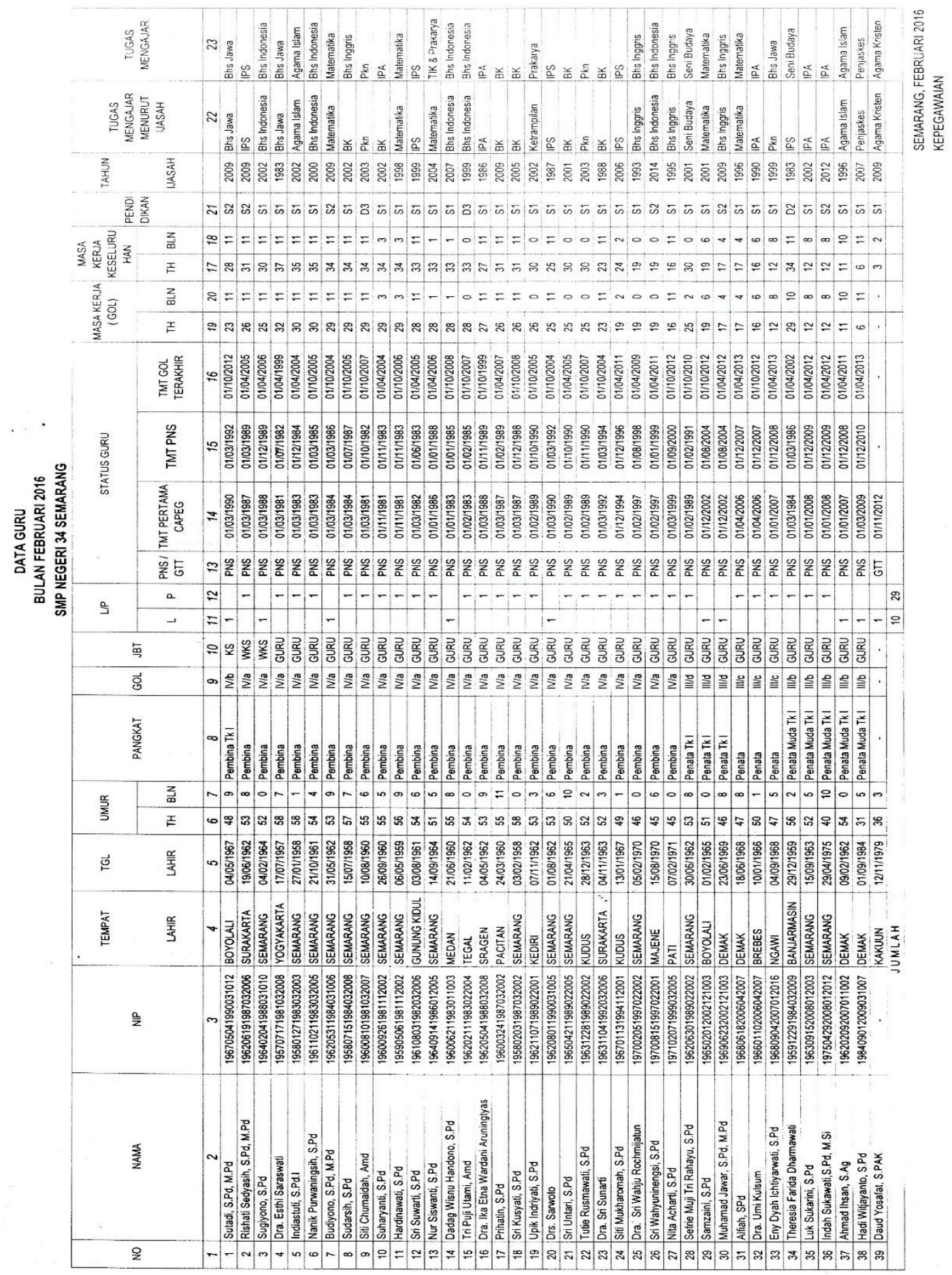


Lampiran 9

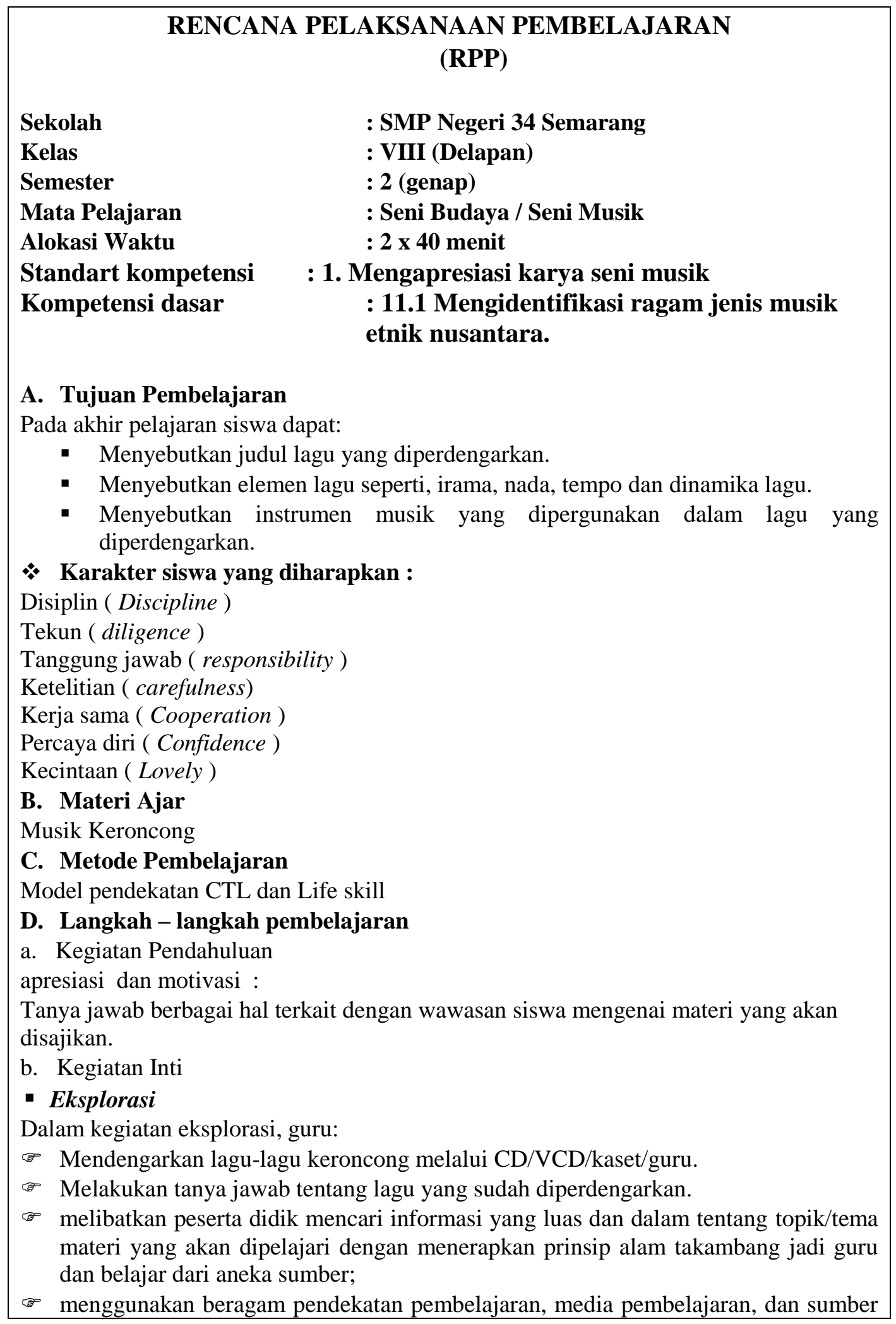




\footnotetext{
belajar lain;

$\leftarrow$ memfasilitasi terjadinya interaksi antar peserta didik serta antara peserta didik dengan guru, lingkungan, dan sumber belajar lainnya;

( $\rightarrow$ melibatkan peserta didik secara aktif dalam setiap kegiatan pembelajaran; dan

memfasilitasi peserta didik melakukan percobaan di studio, atau lapangan.

- Elaborasi

Dalam kegiatan elaborasi, guru:

$\leftrightarrow$ membiasakan peserta didik membaca dan menulis yang beragam melalui tugastugas tertentu yang bermakna;

memberi kesempatan untuk berpikir, menganalisis, menyelesaikan masalah, dan bertindak tanpa rasa takut;

Mendiskusikan tentang elemen musik seperti irama, tempo, nada, serta dinamika.

memfasilitasi peserta didik dalam pembelajaran kooperatif dan kolaboratif;

memfasilitasi peserta didik berkompetisi secara sehat untuk meningkatkan prestasi belajar;

$\approx$ memfasilitasi peserta didik membuat laporan eksplorasi yang dilakukan baik lisan maupun tertulis, secara individual maupun kelompok;

$\leftarrow$ memfasilitasi peserta didik untuk menyajikan hasil kerja individual maupun kelompok;

$\leftrightarrow$ memfasilitasi peserta didik melakukan pameran, turnamen, festival, serta produk yang dihasilkan;
}

\section{- Konfirmasi}

Dalam kegiatan konfirmasi, guru:

$\varpi$ memberikan umpan balik positif dan penguatan dalam bentuk lisan, tulisan, isyarat, maupun hadiah terhadap keberhasilan peserta didik,

memberikan konfirmasi terhadap hasil eksplorasi dan elaborasi peserta didik melalui berbagai sumber,

memfasilitasi peserta didik melakukan refleksi untuk memperoleh pengalaman belajar yang telah dilakukan,

$\approx$ memfasilitasi peserta didik untuk memperoleh pengalaman yang bermakna dalam mencapai kompetensi dasar:

$>$ berfungsi sebagai narasumber dan fasilitator dalam menjawab pertanyaan peserta didik yang menghadapi kesulitan, dengan menggunakan bahasa yang baku dan benar;

$>$ membantu menyelesaikan masalah;

$>$ memberi acuan agar peserta didik dapat melakukan pengecekan hasil eksplorasi;

$>$ memberi informasi untuk bereksplorasi lebih jauh;

$>$ memberikan motivasi kepada peserta didik yang kurang atau belum berpartisipasi aktif.

3. Kegiatan Penutup

Dalam kegiatan penutup, guru:

$\rightarrow$ bersama-sama dengan peserta didik dan/atau sendiri membuat rangkuman/simpulan pelajaran;

melakukan penilaian dan/atau refleksi terhadap kegiatan yang sudah dilaksanakan secara konsisten dan terprogram;

memberikan umpan balik terhadap proses dan hasil pembelajaran;

$\leftarrow$ merencanakan kegiatan tindak lanjut dalam bentuk pembelajaran remedi, program pengayaan, layanan konseling dan/atau memberikan tugas baik tugas individual 
maupun kelompok sesuai dengan hasil belajar peserta didik;

\section{E. Alat/Sumber Belajar}

Buku "Seni Budaya .

$\mathrm{VCD}, \mathrm{CD}$, kaset, guru

\section{F. Penilaian}

Penilaian dilaksanakan selama proses dan sesudah pembelajaran

\begin{tabular}{|c|c|c|c|c|}
\hline & \multirow[b]{2}{*}{$\begin{array}{c}\text { Indikator Pencapaian } \\
\text { Kompetensi }\end{array}$} & \multicolumn{3}{|r|}{ Penilaian } \\
\hline & & Teknik & $\begin{array}{c}\text { Bentuk } \\
\text { Instrumen }\end{array}$ & $\begin{array}{l}\text { Contoh } \\
\text { Instrumen }\end{array}$ \\
\hline $\begin{array}{l}\partial \\
\partial \\
\theta\end{array}$ & $\begin{array}{l}\text { Mampu menyebutkan } \\
\text { beragam karya musik } \\
\text { Nusantara sesuai dengan } \\
\text { intrumen musik yang } \\
\text { digunakan } \\
\text { Mengidentifikasi jenis alat } \\
\text { musik nusantara } \\
\text { Mendiskripsikan sumber } \\
\text { bunyi dari jenis alat musi } \\
\text { Menyanyikan } 1 \text { lagu } \\
\text { nusantara. }\end{array}$ & $\begin{array}{l}\text { Tes } \\
\text { Tertulis }\end{array}$ & Tes Uraian & 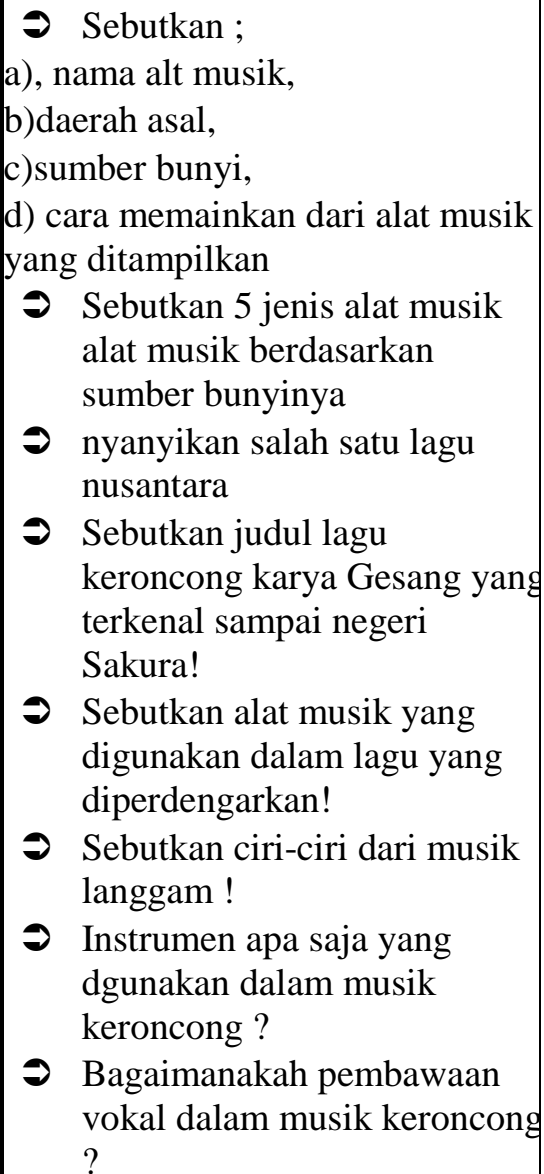 \\
\hline
\end{tabular}




\section{Lampiran 10}

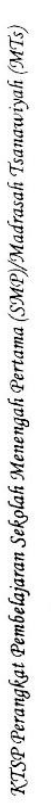

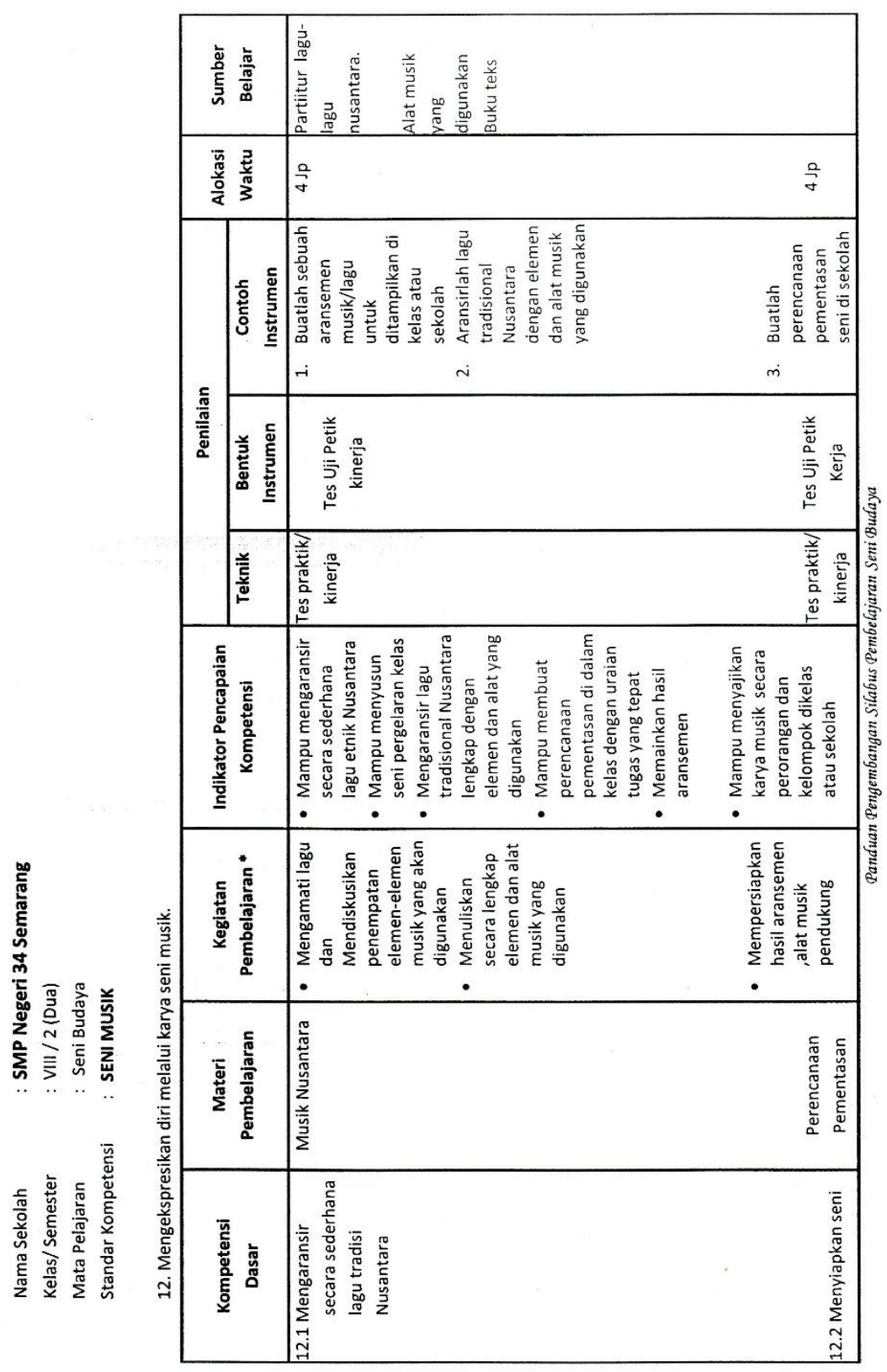




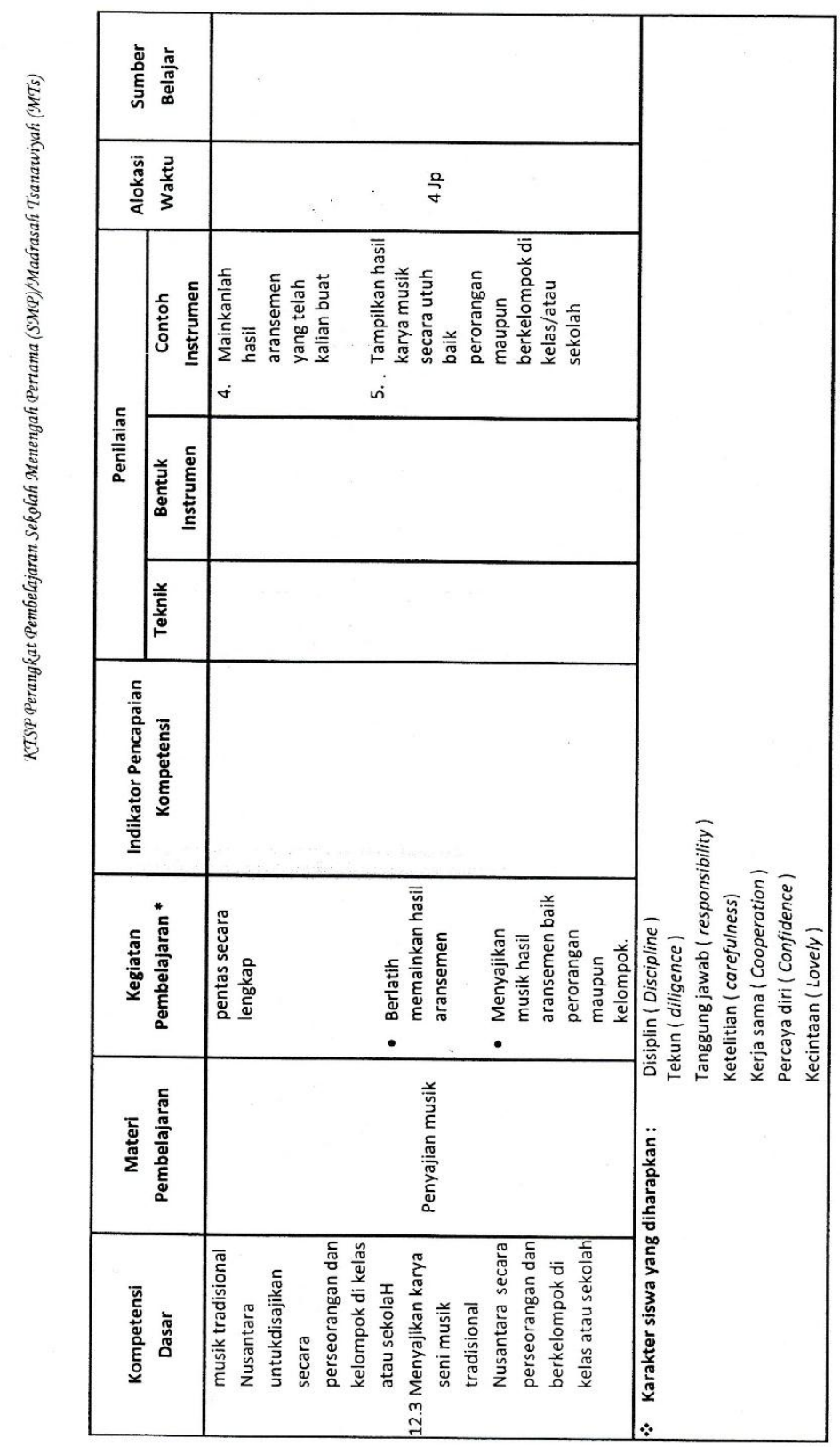

